Ketrampilan Dasar $\Omega 3$ Klinik Kebidanan 


\title{
BUKU AJAR MATA KULIAH \\ KETRAMPILAN DASAR KLINIK KEBIDANAN 1
}

\author{
Oleh \\ Siti Cholifah, SST.,M.Keb. \\ Nurul Azizah, S.Keb.,Bd.,M.Sc
}

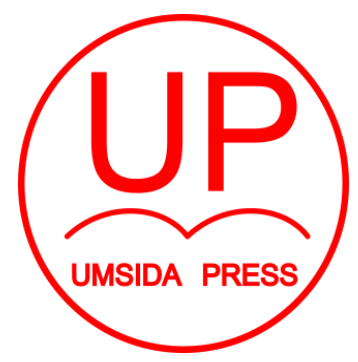

Diterbitkan oleh UMSIDA PRESS

UNIVERSITAS MUHAMMADIYAH SIDOARJO

2020 
BUKU AJAR

KETRAMPILAN DASAR KLINIK KEBIDANAN 1

Penulis :

Siti Cholifah, S.ST., M.Keb.

Nurul Azizah, S.Keb.,Bd., M.Sc.

ISBN :

978-623-6833-13-1

\section{Editor :}

Hesty Widowati, S.Keb., BD., M.Keb.

\section{Copy Editor :}

Mahardika Darmawan Kusuma Wardana, M.Pd

Design Sampul dan Tata Letak :

Mochamad Nashrullah, S.Pd.

Amy Yoga Prajati, S.Kom.

\section{Penerbit :}

UMSIDA Press

Anggota IKAPI No. 218/Anggota Luar Biasa/JTI/2019

Anggota APPTI No. 0020181092017

\section{Alamat Redaksi :}

Universitas Muhammadiyah Sidoarjo

Jl. Mojopahit No 666B

Sidoarjo, Jawa TImur

Cetakan pertama, November 2020

(C) Hak cipta dilindungi undang-undang

Dilarang memperbanyak karya tulis ini dengan suatu apapun tanpa ijin tertulis dari penerbit. 


\section{KATA PENGANTAR}

Assalammu'alaikum Wr.Wb

Puji syukur kami panjatkan kehadirat Allah SWT yang telah memberikan rahmat dan karuniaNya, sehingga kami bisa menyusun buku ajar Ketrampilan Dasar klinik Kebidanan 1 Sholawat dan salam kami haturkan kepada junjungan Nabi Muhammad SAW. Buku ini bertujuan untuk meningkatkan pengetahuan dan pemahaman mengenai ketrampilan Dasar Klinik kebidanan. Buku ini membahas mengenai konsep manusia, konsep sehat dan sakit, stres dan adaptasi, Keselamatan pasien dan Pencegahan infeksi, Kebutuhan dasar manusia dan pemberian obat dalam praktik kebidanan. Penyusunan buku ajar ketrampilan Dasar Klinik kebidanan. tidak lepas dari bantuan dan bimbingan serta motivasi dari semua pihak. Kami berharap dapat membawa manfaat bagi seluruh mahasiswa, terutama mahasiswa semester II. Kami mengharapkan saran dan masukan dari para pembaca, sehingga dapat memperbaiki dikemudian hari.

Wassalamualaikum Wr.Wb

Sidoarjo, September 2020

Tim Penulis 


\section{DAFTAR ISI}

HALAMAN SAMPUL ............................................................. i

KATA PENGANTAR ............................................................... ii

DAFTAR ISI......................................................................................

\section{BAB I KONSEP DASAR MANUSIA}
A. Manusia Sebagai Makluk BIOPSIKOSOSIAL dan SPIRITUAL................................................................... 1
B. Manusia Sebagai Sistem......................................... 1
C. Kebutuhan Dasar Manusia .................................... 2

BAB II KONSEP SEHAT SAKIT
A. Pengertian Sehat-Sakit...................................... 10
B. Hubungan Sehat Sakit......................................... 11
C. Faktor Yang mempengaruhi Status Kesehatan... 13
D. Rentang Sehat sakit........................................... 15
E. Tahapan Proses Sakit........................................... 16
F. Dampak Sakit Dan dirawat.................................... 18

\section{BAB III STRES DAN ADAPTASI}
A. Pengertian Stress
B. Sumber Stresor.
C. Macam-Macam stres
D. Model Stres- Kesehatan. 24
E. Faktor Pengaruh Respon Terhadap Stresor...... 25
F. Tahapan Stres. 26
G. Reaksi Tubuh Terhadap Sress. 26
H. Stres Pada Siklus Kehidupan Wanita.. 28
I. Cara Menilai Stres. 30
J. Konsep Adaptasi................................................. 33
K. Macam-macam Adaptasi..................................... 34 
L. Manajemen Stres.................................................. 37

M. Peran Bidan Dalam Mengatasi Stres.................. 37

BAB IV KESELAMATAN PASIEN DAN PENCEGAHAN INFEKSI

A. Keselamatan Pasien (Patient Safety)................... 42

B. Pencegahan Infeksi

1. Sejarah Dan dasar pelaksanaan kewaspadaan universal.......................................................... 50

2. Pengenalan lingkungan fisik dalam pelayanan kebidanan............................................................ 51

3. Prinsip dalam pencegahan infeksi

a. Transmisi kuman............................................ 51

b. Cara penularan ............................................. 51

c. Tindakan Pencegahan Infeksi (Cuci Tangan, APD, Teknik Aseptik, Pemrosesan Alat dan Pengelolahan Sampah................................. 55

\section{BAB V KEBUTUHAN DASAR MANUSIA}

A. Pemenuhan kebutuhan Cairan dan elektrolit..... 77

B. Pemenuhan kebutuhan oksigen............................. 86

C. Pemenuhan kebutuhan nutrisi.............................. 97

D. Pemenuhan Kebutuhan isirahat dan tidur......... 104

E. Pemenuhan kebutuhan mekanik tubuh, Posisi, ambulasi dan mobilitas......................................... 110

F. Pemenuhan kebutuhan personal hygiene....... 117

G. Pemenuhan Kebutuhan eleminasi.................... 125

\section{BAB VI PEMBERIAN OBAT DALAM PRAKTIK KEBIDANAN}
A. Definisi obat
B. Bentuk obat
C. Penggolongan Obat................................................. 141
D. Persiapan pemberian............................................... 144
E. perhitungan Dosis.................................................... 146 
F. Penggunaan unit Dosis obat................................ 147

G. Faktor yang mempengaruhi dosis obat................. 148

H. Reaksi Obat............................................................ 148

I. Plebotomi, vena punktur dan terapi IV................ 151

J. Transfusi Darah.......................................................... 155

K. Teknik Pemberian Obat........................................ 160

L. Manajemen Nyeri Non Farmakologi...................... 190 


\section{BATANG TUBUH DAN}

SUB-CAPAIAN PEMBELAJARAN MATA KULIAH

\begin{tabular}{|c|c|}
\hline $\mathrm{BAB}$ & Sub Capaian Pembelajaran mata Kuliah \\
\hline $\begin{array}{l}\text { BAB I } \\
\text { Konsep Dasar } \\
\text { Manusia }\end{array}$ & $\begin{array}{l}\text { a. Mahasiswa mampu menjelaskan } \\
\text { manusia sebagai Makluk } \\
\text { BIOSPIKOSOSIAL Dan SIRITUAL } \\
\text { b. Mahasiswa mampu menjelaskan } \\
\text { manusia Sebagai Sistem } \\
\text { c. Mahasiswa mampu menyebutkan } \\
\text { Kebutuhan Dasar Manusia Menurut } \\
\text { Abraham Maslow } \\
\text { d. Mahasiswa mampu menjelaskan ciri } \\
\text { Kebutuhan Dasar Manusia } \\
\text { e. Mahasiswa mampu menjelaskan faktor } \\
\text { yang mempengaruhi Kebutuhan Dasar } \\
\text { manusia }\end{array}$ \\
\hline $\begin{array}{l}\text { BAB II } \\
\text { Konsep Sehat Sakit }\end{array}$ & $\begin{array}{l}\text { a. Mahasiswa mampu menjelaskan } \\
\text { pengertian Sehat-Sakit } \\
\text { b. Mahasiswa mampu menjelaskan } \\
\text { hubungan Sehat Sakit } \\
\text { c. Mahasiswa mampu menyebutkan faktor } \\
\text { Yang mempengaruhi Status Kesehatan } \\
\text { d. Mahasiswa mampu menjelaskan } \\
\text { tahapan Proses Sakit } \\
\text { e. Mahasiswa mampu menjelaskan } \\
\text { dampak Sakit Dan dirawat }\end{array}$ \\
\hline $\begin{array}{l}\text { BAB III } \\
\text { Stres Dan Adaptasi }\end{array}$ & $\begin{array}{l}\text { a. Mahasiswa mampu menjelaskan } \\
\text { pengertian Stress } \\
\text { b. Mahasiswa mampu menjelaskan sumber } \\
\text { Stresor } \\
\text { c. Mahasiswa mampu menjelaskan } \\
\text { macam-Macam stres }\end{array}$ \\
\hline
\end{tabular}




\begin{tabular}{|l|l|}
\hline & $\begin{array}{l}\text { d. Mahasiswa mampu menjelaskan model } \\
\text { Stres- Kesehatan }\end{array}$ \\
e. Mahasiswa mampu menyebutkan faktor \\
Pengaruh Respon Terhadap Stresor \\
f. Mahasiswa mampu menjelaskan \\
tahapan Stres \\
g. Mahasiswa mampu menjelaskan reaksi \\
tubuh Terhadap Sress \\
h. Mahasiswa mampu menjelaskan stres \\
Pada Siklus Kehidupan Wanita \\
i. Mahasiswa mampu menerapkan cara \\
Menilai Stres
\end{tabular}




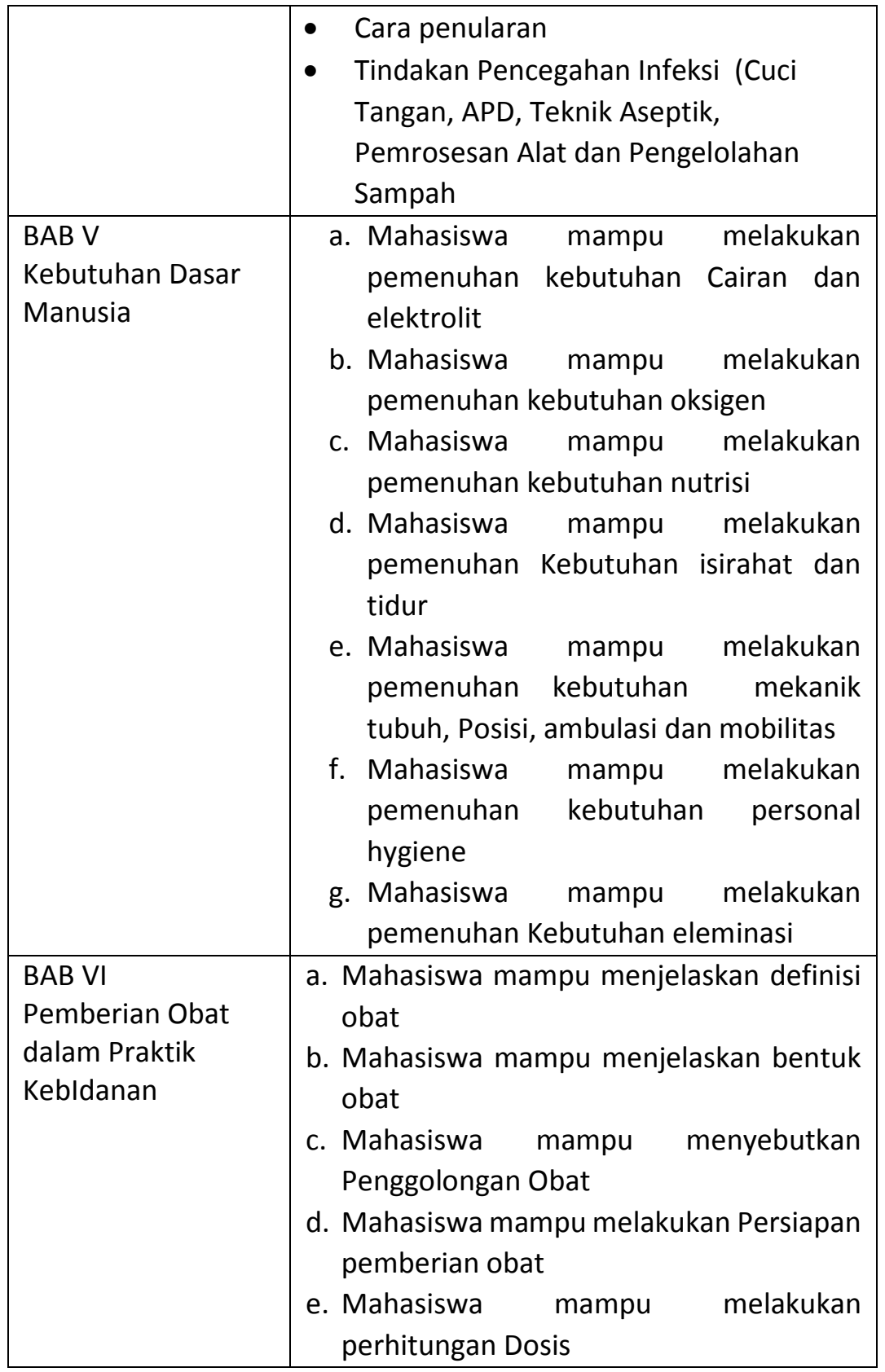




\begin{tabular}{|l|l|}
\hline f. Mahasiswa mampu melakukan \\
penggunaan unit Dosis obat \\
g. Mahasiswa mampu mengidentifikasi \\
Reaksi Obat \\
h. Mahasiswa mampu mengidentifikasi \\
reaksi obat \\
i. Mahasiswa mampu melakukan \\
Plebotomi, venapunktur dan terapi IV \\
j. Mahasiswa mampu melakukan transfusi \\
Darah \\
k. Mahasiswa mampu melakukan teknik \\
Pemberian Obat \\
I. Mahasiswa mampu melakukan \\
manajemen nyeri non farmakologi
\end{tabular}




\section{BAB I}

\section{KONSEP DASAR MANUSIA}

\section{Tujuan pembelajaran :}

Mahasiswa mampu menjelaskan manusia sebagai makluk BIOSPIKOSOSIAL dan SPIRITUAL, sebagai Sistem, Kebutuhan dasar manusia menurut beberapa ahli, ciri kebutuhan dan faktor yang mempengaruhi kebutuhan dasar manusia

\section{A. Manusia sebagai Makluk BIOSPIKOSOSIAL Dan SIRITUAL}

Manusia sebagai makluk biopsikosial dan spiritual atau disebut juga sebagai makluk yang utuh atau holistik yang terdiri dari berbagai unsur yaitu biologis, psikologis sosial dan spiritual. Unsur biologis merupakan manusia terdiri dari susunan sistem organ tubuh yang digunakan untuk mempertahankan hidupnya mulai dari proses kelahiran, perkembangan dan proses kematian. Sebagai makluk psikologi manusia mempunyai struktur kepribadian, tingkah laku dan manifestasi dari kejiwaan, mempunyai daya piker dan kecerdasan. Sebagai makluk sosial manusia perlu hidup bersama dengan orang lain, saling bekerjasama untuk memenuhi kebutuhan dan tuntutan hidupnya, mudah dipengaruhi kebudayaan, serta dituntut untuk bertingkah laku sesuai dengan harapan norma yang ada, sesuai dengan harapan dan norma yang ada. Sebagai makluk spiritual manusia mempunyai keyakinan, mengakui adanya Tuhan Yang Maha Esa, memiliki pandangan hidup, dorongan hidup yang sejalan dengan sifat religius yang dianutnya.

\section{B. Manusia Sebagai Sistem}

Manusia sebagai sistem terdiri atas sistem adaptif, personal, interpersonal dan sosial. Sebagai sistem adaptif manusia mengalami 
proses perubahan individu dalam berespon terhadap lingkungan yang dapat mempengaruhi integritas atau keutuhan. Sebagai sistem personal manusia memiliki persepsi dan tumbuh kembang. Sebagai sistem interpersonal manusia dapat berinteraksi, berperan, dan berkomunikasi. Manusia memiliki kekuatan, otoritas dan pengambilan keputusan hal ini menunjukkan manusia sebagai suatu sistem.

\section{Kebutuhan Dasar Manusia}

\section{Konsep Kebutuhan Dasar manusia}

Manusia mempunyai kebutuhan dasar mulai dari kebutuhan fisiologis, rasa aman, memiliki harga diri dan aktualisasi diri. Kebutuhan dasar yang dimiliki manusia bersifat heterogen. Walaupun kebutuhan dasar setiap manusia sama, tetapi cara pemenuhan kebuituhan bisa berbeda menyesuaikan prioritas dan dipengaruhi budaya.

\section{Pendapat beberapa ahli tentang kebutuhan manusia}

\section{a. Menurut Abraham Maslow}

Kebutuhan dasar manusia menurut Abraham Maslow dibagi dalam lima tingkatan yaitu sebagai berikut:

\section{1) Kebutuhan Fisiologi}

Kebutuhan paling dasar dan memiliki prioritas utama yaitu kebutuhan fisiologi. Kebutuhan ini mutlak harus terpenuhi agar manausia bisa mempertahankan hidup. Kebutuhan ini meliputi kebutuhan pemenuhan oksigen cairan, nutrisi (makanan), eliminasi BAB/BAK, istirahat dan tidur, aktivitas/ latihan, keseimbangan suhu tubuh, dan kebutuhan seksual,

\section{2) Kebutuhan rasa aman}

Kebutuhan rasa aman baik secara fisik maupun psikologis. Secara fisik yaitu aman dari ancaman seperti penyakit, kecelakaan, bahaya dari lingkungan dan sebagainya, sedangkan secara psikologis, yaitu perlindungan atas ancaman, pengalaman baru atau yang kurang menyenangkan, seperti contoh kekhawatiran tinggal ditempat baru.

3) Kebutuhan rasa cinta dan kasih sayang 
Kebutuhan rasa cinta dan kasih sayang yaitu kebutuhan akan perasaan untuk memiliki dan dimiliki, mencintai dan dicintai, meliputi memberi dan menerima kasih sayang, kebutuhan kehangatan, menjalin persahabatan, dan diterima dalam keluarga, kelompok sosial dan masyarakat.

4) Kebutuhan akan harga diri

Merupakan kebutuhan perasaan untuk dihargai oleh orang lain, mendapatkan pengakuan dari orang lain hal ini terkait dengan rasa percaya diri, prestasi keinginan untuk mendapatkan kekuatan dan kemerdekaan diri.

5) Kebutuhan aktualiasasi diri,

Kebutuhan yang terakhir ini merupakan kebutuhan dalam hierarki Maslow yang tertinggi, yang berkaitan dengan konstribusi manusia bagi orang lain dan lingkungannya.

Kebutuhan menurut A. Maslow di gambarkan sebagai piramida Kebutuhan seperti dibawah ini :

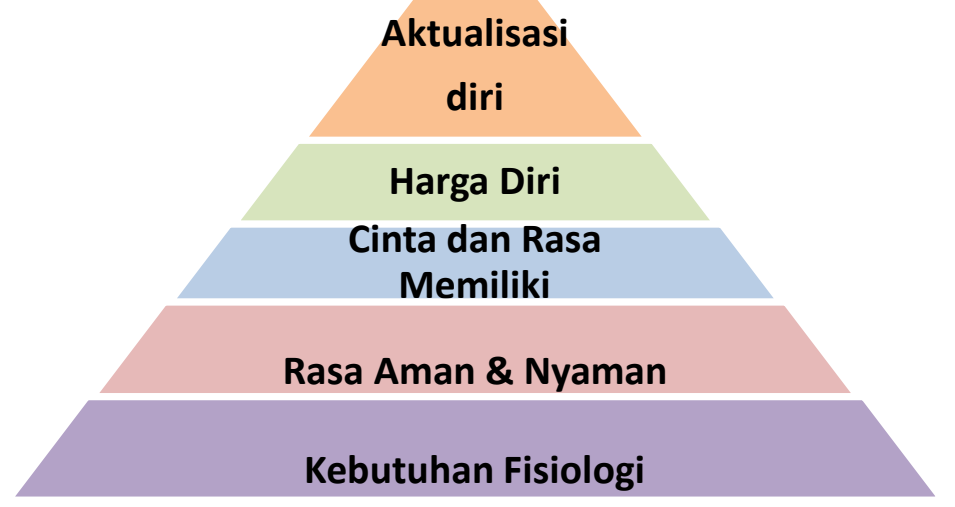

Gb.1.1 Piramida : Kebutuhan Dasar A. Maslow

\section{b. Menurut Imogine King}

King berpendapat bahwa manusia merupakan individu reaktif yang dapat bereaksi terhadap situasi orang dan objek tertentu. King 
menjelaskan bahwa manusia sebagai makhluk yang berorientasi pada waktu, manusia terkait dengan tiga kejadian dalam hidupnya, yaitu kejadian pada masa lalu, sekarang dan masa depan. Sebagai makhluk social manusia selalu berinteraksi satu sama yang lain serta hidup bersama orang lain. Berdasarkan kondisi tersebut kebutuhan manusia dibagi menjadi 3 kebutuhan oleh King yaitu: kebutuhan Informasi kesehatan pencegahan penyakit dan perawatan jika sakit.

\section{c. Menurut Martha E. Rogers}

Manusia merupakan satu kesatuan yang utuh serta memiliki sifat dan karakter yang berbeda. Manusia selalu berinteraksi dengan lingkungan dan saling mempengaruhi satu dengan yang lainnya. Dalam proses kehidupannya, manusia diciptakan dengan karakteristik dan keunikan nya masing-masing. Dengan kata lain, setiap individu tidak ada yang sama satu sama yang lainnya, walaupun mereka dilahirkan kembar. Konsep Martha E. Rogers ini dikenal dengan konsep manusia sebagai unit.

\section{d. Menurut Johnson}

Johnson mengungkapkan pandangannya dengan menggunakan pendekatan sistem

perilaku. Dalam pendekatan ini, individu dipandang sebagai sistem perilaku yang selalu ingin mencapai keseimbangan dan stabilitas, baik dalam lingkungan internal maupun eksternal. Individu juga memiliki keinginan untuk mengatur dan menyesuaikan dirinya terhadap pengaruh yang terjadi karena hal tersebut.

\section{e. Menurut Virginia Henderson}

Virginia Henderson membagi kebutuhan dasar manusia ke dalam 14 komponen berikut yaitu manusia harus dapat bernafas secara normal, makan dan minum yang cukup, setiap hari harus bisa buang air besar dan buang air kecil (eliminasi) dengan lancar, bisa bergerak dan mempertahankan postur tubuh yang diinginkan, terpenuhi kebutuhan tidur dan istirahat dengan nyaman, kebutuhan pakaian yang tepat dan nyaman dipakai sesuai yang dipilihnya, mempertahankan suhu tubuh dalam kisaran normal dengan 
menyesuaikan pakaian yang dikenakan dan memodifikasikan lingkungan, menjaga kebersihan diri dan penampilan, menghindari bahaya dari lingkungan dan menghindari membahayakan orang lain, berkomunikasi dengan orang lain dalam mengekspresikan emosi, kebutuhan, kekhawatiran, dan opini, beribadah sesuai dengan agama dan kepercayaan, bekerja sedemikian rupa sebagai modal untuk membiayai kebutuhan hidup, bermain atau berpartisipasi dalam berbagai bentuk rekreasi dan belajar, menemukan atau memuaskan rasa ingin tahu yang mengarah pada perkembangan yang normal, kesehatan dan penggunaan fasilitas kesehatan yang tersedia.

\section{f. Menurut Jean Wat}

Jean Watson membagi kebutuhan dasar manusia ke dalam dua peringkat utama yaitu kebutuhan yang tingkatnya lebih rendah (lower order needs) dan kebutuhan yang tingkatnya lebih tinggi (higher order needs). Pemenuhan kebutuhan yang tingkatnya lebih rendah tidak selalu membantu upaya kompleks manusia untuk mencapai aktualisasi diri. Tiap kebutuhan dipandang dalam konteksnya terhadap kebutuhan lain, dan semuanya dianggap penting.

\section{g. Menurut Sister Calista Roy}

Manusia sebagai individu yang mampu mempertahankan perilaku yang adaptif dan mengubah perilaku mal adaptif sehingga individu dapat meningkatkan status kesehatan. Untuk mencapai suatu posisi seimbang/homeostasis, manusia harus bisa beradaptasi dengan perubahan yang terjadi. Adaptasi bisa dilakukan dengan beberapa rangsangan, yaitu: rangsangan fokal, konstektual dan residual. Dalam proses penyesuaian diri, individu harus meningkatkan energinya agar mampu mencapai tujuan berupa kelangsungan hidup, perkembangan, reproduksi serta keunggulan. Dengan demikian individu selalu mempunyai tujuan untuk respons adaptif. Bila disingkat pendapat Roy, dikatakan bahwa individu sebagai makhluk biopsikososiospiritual merupakan satu kesatuan yang utuh, memiliki mekanisme koping untuk beradaptasi dengan perubahan lingkungan 
yang terjadi melalui interaksi yang dilakukan terhadap perubahan lingkungan tersebut.

\section{Ciri-ciri Kebutuhan Dasar Manusia}

Ciri-ciri kebutuhan dasar manusia adalah sebagai berikut:

a. Setiap orang mempunyai kebutuhan dasar yang sama, walaupun memiliki perbedaan bidang sosial, budaya, persepsi dan pengetahuan.

b. Secara umum pemenuhan kebutuhan sesuai dengan tingkat prioritasnya.

c. Sebagian pemenuhan kebutuhan dasar manusia dapat ditunda walaupun harus dipenuhi.

d. Kegagalan pemenuhan salah satu kebutuhan dasar menyebabkan ketidakseimbangan sehingga berakibat sakit.

e. Keinginan memenuhi kebutuhan dipengaruhi stimulus internal dan eksternal. Contoh kebutuhan minum, seseorang yang merasa haus, maka ia ingin segera minum. Hal ini disebabkan dalam tubuhanya kekurangan cairan (stimulus internal) atau karena melihat minuman yang segar saat terik matarahi (stimulus eksternal).

f. Berbagai kebutuhan dasar akan saling berhubungan dan dan berpengaruh pada manusia. Misalnya kebutuhan makan akan diikuti dengan kebutuhan minum.

g. Manusia dapat merasakan adanya kebutuhan dan berusaha untuk segera memenuhi kebutuhan tersebut.

4. Beberapa faktor yang mempengaruhi kebutuhan dasar manusia adalah sebagai berikut:

a. Hubungan keluarga

Rasa saling percaya satu dengan yang lain dalam hubungan keluarga bisa meningkatkan pemenuhan kebutuhan dasar.

b. Konsep diri 
Konsep diri yang positif memberikan makna dan keutuhan bagi seseorang. Konsep diri yang sehat menghasilkan perasaan dan kekuatan positif sehingga mudah mengenali kebutuhannya

c. Penyakit,

Organ tubuh memerluhkan kebutuhan lebih dalam kondisi sakit. Selain itu sakit menyebabkan perubahan pemenuhan kebutuhan baik secara fisiologis maupun psikologis.

d. Tahap perkembangan

Bertambahnya usia, manusia akan mengalami perkembangan. Setiap tahap perkembangan memiliki kebutuhan yang berbeda., jadi dari bayi baru lahir sampai dengan kita tutup usia kebutuhan tetap akan berkembang sesuai dengan berjalannya umur.

e. Struktur keluarga

Keluarga merupakan sistem pendukung dalam diri seseorang. Struktur keluarga dapat mempengaruhi seseorang memuaskan kebutuhannya.

\section{Kesimpulan}

1. Manusia disebut sebagai makluk biopsikosial dan spiritual atau disebut juga sebagai makluk yang utuh atau holistik yang terdiri dari berbagai unsur yaitu biologis, psikologis sosial dan spiritual.

2. Manusia sebagai sistem terdiri atas sistem adaptif, personal, interpersonal dan sosial.

3. Menurut Abraham Maslow kebutuhan dasar manusia ada 5 yaitu kebutuhan biologis, rasa aman dan nyaman, mencintai dan dicintai, harga diri dan aktualisasi diri.

4. Ciri-ciri kebutuhan dasar manusia sama pada semua orang, pemenuhan tergantung prioritas masing-masing, kebutuhan dasar saling berhubungan.

5. Factor yang mempengaruhi kebutuhan dasar manusia yaitu hubungan keluarga, konsep diri, penyakit, tahap perkembangan dan struktur keluarga. 


\section{Latihan Soal:}

1. Jelaskan manusia sebagai makluk BIOPSIKOSOSIAL dan SPIRITUAL!

2. Jelaskan manusia sebagai system!

3. Jelaskan kebutuhan dasar manusia menurut hirarki Abraham Maslow!

4. Sebutkan ciri-ciri kebutuhan dasar manusia!

5. Jelaskan faktor yang mempengaruhi kebutuhan dasar manusia!

\section{Daftar Pustaka}

Uliyah,M, Wildan M., Surachmindari dan Hidayat, A. Aziz Alimul. 2012. Ketrampilan Dasar Kebidanan I (pendekatan kurikulum Berbasis Kompetensi). Surabaya: Health Books Publishing

Yuni, Natalia E Dan Oktami, Rika S. 2014. Ketrampilan Dasar Praktik Klinik Kebidanan . Yogyakarta: Nuha Medika. 


\section{BAB II \\ KONSEP SEHAT SAKIT}

\section{Tujuan pembelajaran:}

Mahasiswa mampu menjelaskan pengertian Sehat-Sakit, hubungan sehat- sakit, faktor yang mempengaruhi Status Kesehatan, tahapan proses sakit dan dampak sakit serta dirawat.

\section{A. Pengertian Sehat-Sakit}

Menurut WHO (1947) Definisi Sehat adalah suatu keadaan yang sempurna baik fisik, mental dan sosial tidak hanya bebas dari penyakit atau kelemahan.

Menurut Undang-undang N0. 36 tahun 2009 tentang kesehatan bahwa definisi kesehatan adalah keadaan sehat, baik secara fisik, mental, spritual maupun sosial yang memungkinkan setiap orang untuk hidup produktif secara sosial dan ekonomis.

Seseorang dikatakan sakit apabila ia menderita penyakit menahun (kronis) atau gangguan kesehatan lain yang menyebabkan aktivitas kerja atau kegiatannya terganggu. Walaupun seseorang sakit, istilah masuk angin , pilek tetapi bila ia tidak terganggu untuk melaksanakan kegiatannya maka ia dianggap tidak sakit (UU no. 23 tahun 1992) Sakit sebagai suatu keadaan dari badan /sebagian dari organ badan dimana fungsinya terganggu/menyimpang. (Oxford English Dictionary)

\section{B. Hubungan Sehat- Sakit}

Hubungan antara konsep sehat sakit dan penyakit pada dasarnya merupakan keadaan sehat sakit, yaitu : Hasil interaksi seseorang dengan lingkungan. Sebagai manifetasi keberhasilan / kegagalan dalam beradaptasi dengan lingkungan. 
Hubungan sehat sakit dapat dijelaskan melalui beberapa model konsep sehat sakit, diantaranya model ekologi, model the health field concept dan the environment of health (Bustan 1996)

Model Ekologi atau dikenal dengan the traditional ecological model merupakan model status kesehatan seseorang ditentukan adanya hasil interaksi antara host (tuan rumah), agent dan lingkungan. Hubungan interakasi yang positif akan menimbulkan kondisi yang seimbang (sehat), dan bila salah satu terjadi kondisi tidak seimbang maka ada salah satu yang mengalami kemampuan yang menurun yang menimbulkan sakit, sebagaimana digambarkan sebagai berikut :

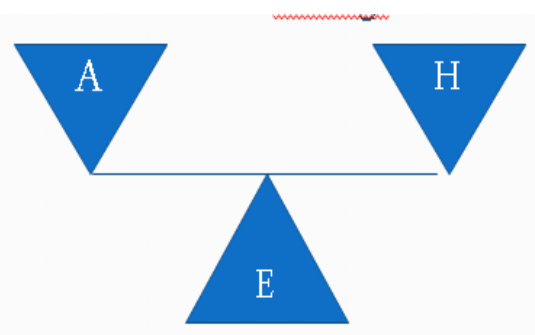

Gb. 2.1 Kondisi Seimbang (Equilibrium )= Sehat

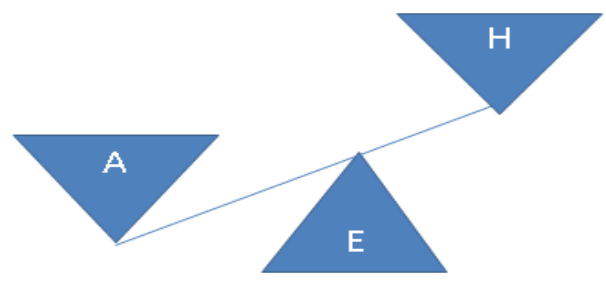

Gb. 2.2 Kondisi tidak Seimbang - Sakit

Model selanjutnya adalah model the health field concept yang menjelaskan ada 4 faktor yang berperan dalam kondisi status kesehatan diantaranya adalah faktor lingkungan, gaya hidup, biologis 
dan sistem pelayanan kesehatan. Model ini di gambarkan sebagai berikut :

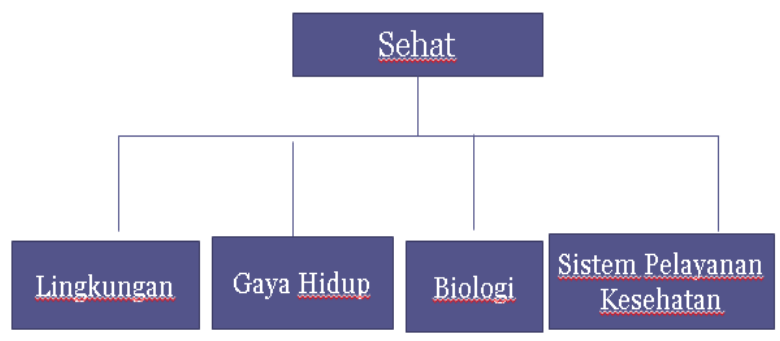

Gb. 2.3 Model the Healthfield concept (Bustan, 1996)

Kemudian model the environment of health yang dikembangkan oleh HL Blum, model ini merupakan pengembangan model sebelumnya dengan memberi penjelasan peranan atau faktor penyebab kondisi sehat-sakit, diantaranya : faktor herediter, faktor pelayanan kesehatan, gaya hidup dan faktor lingkungan yang memiliki peran yang sangat besar. Model ini dapat digambarkan sebagai berikut:

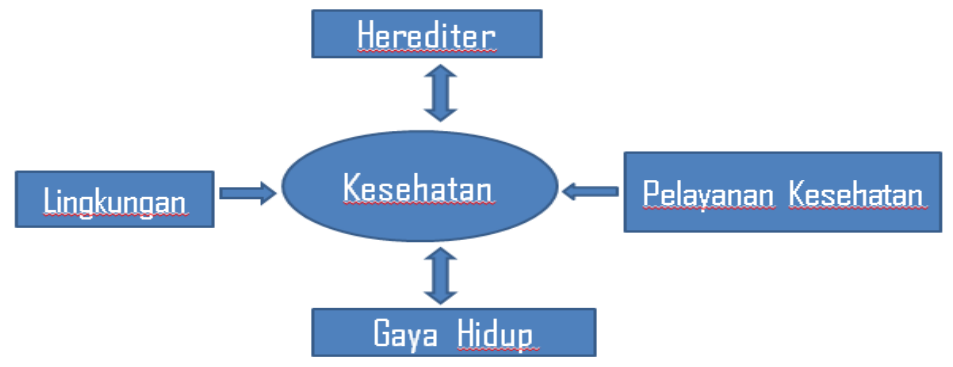

Gb. 2.4 the environment of health (Bustan 1996)

Dari beberapa model tersebut diatas muncul istilah penyakit yang menurut pandangan medis memiliki arti suatu gangguan fungsi tubuh yang mengakibatkan berkurangnya kapasitas tubuh sehingga responya berupa sakit. Selanjutnya hubungan seghat sakit dapat digambarkan sebagai berikut : 

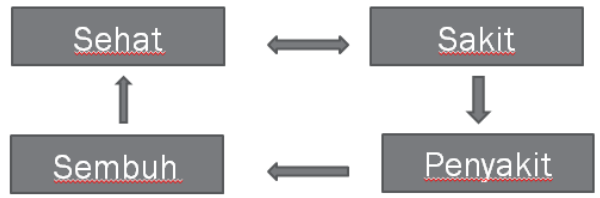

Gb. 2.5 Hubungan sehat sakit

\section{Faktor Pengaruh Status Kesehatan}

Status kesehatan merupakan suatu keadaan kesehatan seseorang dalam rentang sehat-sakit yang bersifat dinamis yang dapat dipengaruhi oleh perkembangan, social kultural, pengalaman masa lalu, harapan seseorang tentang dirinya, keturunan, lingkungan dan pelayanan.

\section{Perkembangan}

Status kesehatan dapat dipengaruhi oleh faktor perkembangan yang mempunyai arti bahwa perubahan status kesehatan dapat ditentukan oleh faktor usia dalam hal ini usia tumbuh kembang, mengingat proses perkembangan itu dimulai dari bayi sampai usia lanjut yang memiliki pemahaman dan respon terhadap perubahan kesehatan yang berbeda-beda. Respon seseorang terhadap perubahan kesehatan mempengaruhi kondisi kesehatannya. Kondisi kesehatan bayi sangat dipengaruhi perkembangan karena belum mencapai kematangan dari organ tubuh sehingga bayi rentan terkena penyakit. Demikian juga dengan orang usia lanjut rentan sekali terhadap sakit karena kondisi daya tahan tubuh yang menurun dan fungsi organ yang lain juga mengalami penurunan.

2. Harapan seseorang tentang dirinya

Harapan seseorang akan menimbulkan motivasi untuk meningkatkan status kesehatan baik secara fisik maupun psikologis serta dapat menghindari hal-hal yang dapat mempengaruhi status 
kesehatan, Sehingga harapan menjadi bagian terpenting dalam meningkatkan perubahan status kesehatan.

3. Sosial kultural

Faktor sosial kultural akan mempengaruhi pola pikir dan keyakinan seseorang sehingga bisa menyebabkan perubahan status kesehatan, Misalnya Tinggal dilingkungan kumuh jia dia tidak / jarang terkena penyakit, maka mereka bisa beranggapan mereka dalam kondisi sehat.

4. Faktor Pengalaman

Perubahan status kesehatan dipengaruhi pengalaman masa lalu seseorang. Jika pengalaman kesehatan masa lalu yang dialami kurang menyenangkan bisa berdampak pada status kesehatan selanjutnya, misalnya sesorang pernah mengalami mual muntah akibat keracunan makanan yang dimakannya yang menyebabkan dia sampai dirawat di rumah sakit sehingga dia akan berhati-hati dalam memilih makan yang dikonsumsinya sehari-hari dan berupaya untuk menghindari makan-makanan yang bisa menyebabkan keracunan.

5. Pelayanan

Akses terhadap tempat pelayanan dan kualitas pelayanan yang diberikan akan mempengaruhi status kesehatan seseorang. Misalnya : mengalami kondisi sakit untuk mendapatkan pelayanan kesehatan tempatnya jauh sehingga bisa terlambat untuk mendapatkan penanganan.

6. Keturunan

Meskipun tidak terlalu besar faktor keturunan mempengaruhi kondisi kesehatan seseorang. Sesorang yang mempunyai faktor genetik suatu penyakit mempunyai potensi atau risiko untuk timbul suatu penyakit tersebut dibandingkan dengan yang tidak memiliki faktor genetik.

7. Kondisi Lingkungan 
Keadaan lingkungan yang kurang bersih, pembuangan sampah, limbah dan kotoran serta rumah yang kurang memenuhi standar kesehatan mempengaruhi status kesehatan, dan sebaliknya kondisi lingkungan rumah yang bersih dapat mencegah penyebaran dan penularan penyakit.

\section{Rentang Sehat Sakit}

Rentang sehat sakit terdiri atas rentang sehat dan rentang sakit. Rentang sehat dapat digambarkan.kan mulai dari sejahtera, sehat sekali, sehat normal, sedangkan rentang sakit dimulai dari setengah sakit, sakit, sakit kronis dan berakhir pada kematian.

Rentang ini merupakan alat ukur untuk menilai status kesehatan yang bersifat dinamis dan selalu berubah setiap waktu. Melalui rentang ini dapat diketahui batasan bidan dalam melakukan praktik kebidanan dengan jelas.

Rentang sehat dan sakit dapat digambarkan sebagai berikut:

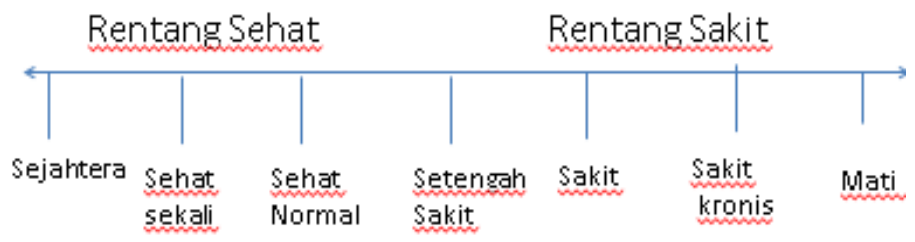

Gb. 2.6 Rentang Sehat sakit

\section{E. Tahapan Proses Sakit}

1. Tahap adanya gejala

Pada tahap ini dimulai dengan timbulnya gejala pada seseorang sebagai manifestasi adanya ketidakseimbangan didalam tubuh. Ini merupakan tanda awal seseorang mengalami sakit. Pada tahap ini 
seseorang mengalami rasa tidak nyaman. Gejala fisik yang timbul bisa berupa panas, nyeri, dan lain-lain.

2. Tahap asumsi terhadap penyakit

Seseorang melakukan melakukan interprestasi terhadap gejala yang timbul dan mulai timbul perasaan ragu terhadap gejala atau kelainan yang dialami pada tahap ini, sehingga dengan adanya rasa takut, kawatir dan kecemasan seseorang merespon dengan menghubungi seseorang yang ada disekitarnya untuk konsultasi.

3. Tahap kontak dengan pelayanan kesehatan

Tahap ini seseorang telah mengadakan hubungan dengan pelayanan kesehatan dengan meminta nasehat dari profesi kesehatan seperti dokter, bidan atau yang lainnya yang dilakukan atas inisiatif sendiri. Proses pencarian informasi ini dilakukan untuk mencarai pembenaran keadaan sakitnya, kemudian untuk mengetahui gejalagejala yang tidak dimengerti oleh klien dan adanya keyakinan bahwa dirinya akan lebih baik. Jika setelah konsultasi tidak ditemukanlagi gejala yang ada, maka klien menganggap dirinya telah sembuh.

4. Tahap Ketergantungan

Tahap seseorang mulai mengalami ketergantungan dalam pengobatan karena mengalami suatu penyakit. Tiap orang memiliki tingkat ketergantungan yang berbeda sesuai dengan kebutuhan. Agar pada tahap ini seseorang mengalami kemandirian maka sangat dibutuhkan dukungan dari tenaga kesehatan dan orang disekitarnya.

5. Tahap Penyembuhan

Tahap terakhir dimana seseorang mulai beradaptasi dan belajar melepaskan perannya selama sakit dan kembali pada perannya seperti semula sebelum sakit. Petugas kesehatan berperan untuk membantu agar klien agar bisa meningkatkan kemadirian dan hidup sejahtera seperti kondisi sebelum sakit.

\section{F. Perilaku Peran Sakit}

1. Timbul perasaan takut 
Setiap orang yang dalam kondisi sakit akan mengalami perubahan perilaku berupa timbulnya rasa takut, Rasa takut ini bisa berdampak pada kesehatan mental jika tidak segera mendapat penanganan.

2. Perilaku menarik diri

Kecemasan yang ditimbulkan akibat sakit, untuk mengurangi kecemasan berperilaku menarik diri, seperti diam jika tidak diberi pertanyaan hal tersebut dilakukan dalam upaya menghindari kecemasan.

3. Egosentri

Perilaku ini dapat terjadi pada orang sakit yang ditunjukkan dengan selalu mempersoalkan dirinya dan tidak mau mendengarkan/ memikirkan orang lain. Perilaku ini juga ditunjukkan dengan selalu ingin bercerita tentang penyakitnya.

4. Sensitif terhadap persoalan kecil

Pada orang sakit perubahan perilaku ini biasanya selalu ditimbulkan dengan selalu mempersoalkan hal-hal kecil sebagai dampak terganggunya psikologis, selalu mengomel jika keadaan tersebut tidak sesuai dengan dirinya.

5. Reaksi emosional tinggi

Perilaku ini ditunjukkan dari seseorang yang mengalami sakit dengan mudah menangis, mudah tersinggung, mudah marah dan menuntut perhatian yang besar pada tenaga kesehatan tersebut.

6. Persepsi yang berubah

Seseorang yang sakit akan mengalami perubahan persepsi, dimana dia menaruh harapan yang sangat besar pada tenaga kesehatan (perawat, dokter, bidan) untuk kesembuhan penyakitnya.

7. Kurangnya minat

Stres akibat sakit akan menimbulkan kurangnya minat dan menurunnya kemampuan untuk melakukan aktifitas sehari-hari.

\section{G. Dampak Sakit Dan Dirawat}


Dampak yang dialami pada individu yang telah mengalami sakit dirawat dirumah sakit maupun di rumah, diantaranya terjadi perubahan peran dalam keluarga, gangguan psikologis, masalah keuangan, kesepian, perubahan kebiasaan, sosial, terganggunya privasi seseorang, otonomi dan terjadi perubahan gaya hidup.

1. Salah satu anggota keluarga yang sakit akan berdampak terjadinya perubahan peran dalam keluarga tersebut, misalnya seorang ayah yang sakit maka peran seorang ibu akan berubah.

2. Timbulnya masalah psikologis, bisa berupa stres sampai kecemasan berat.

3. Masalah keuangan, dampak ini jelas terjadi karena adanya pengeluaran tidak terduga.

4. Kesepian, terjadi akibat dampak harus dirawat sehingga berpisah dari keluarga.

5. Perubahan kebiasaan sosial, ini jelas terjadi karena tidak ada interaksi dengan lingkungan masyarakat.

6. Terganggunya privasi seseorang, hal ini terjadi karena aktifitas terbatas dan pemenuhan kebutuhan terganggu sehingga membuat perasaan menjadi tidak menyenangkan yang mengakibatkan penghargaan social sulit dicapai.

7. Otonomi, ketergantungan dan kemandirian pasien sulit dicapai karena telah disediakan segala kebutuhan bagi pasien di rumah sakit.

8. Perubahan gaya hidup, selama sakit terdapat peraturan yang harus dipatuhi oleh pasien di rumah sakit sehingga pasien mengalami perubahan gaya hidup dan perilaku sehat, serta mematuhi aturan mulai dari makanan, minuman, obat dan aktifitas.

\section{Kesimpulan}

1. Kesehatan adalah keadaan sehat, baik secara fisik, mental, spritual maupun sosial yang memungkinkan setiap orang untuk hidup 
produktif secara sosial dan ekonomis. Sakit sebagai suatu keadaan dari badan /sebagian dari organ badan dimana fungsinya terganggu/menyimpang.

2. Hubungan antara konsep sehat sakit dan penyakit pada dasarnya merupakan keadaan sehat sakit, yaitu : Hasil interaksi seseorang dengan lingkungan.

3. Faktor yang mempengaruhi kesehatan yaitu perkembangan, harapan, sosio kultural, pengalaman, keturunan, pelayanan dan kondisi lingkungan.

4. Rentang sehat mulai dari sejahtera, sehat sekali, sehat normal, sedangkan rentang sakit dimulai dari setengah sakit, sakit, sakit kronis dan berakhir pada kematian.

5. Tahapan sakit dimulai dari munculnya gejala, asumsi terhadap penyakit, kontak dengan pelayanan, ketergantungan dan penyembuhan.

6. Perilaku sakit meliputi takut, menarik diri, egosentris, sensitif, reaksi emosional tinggi, persepsi yang berubah dan kurang minat

7. Dampak sakit dirawat antara lain perubahan peran, masalah psikologis, masalah keuangan, kesepian, perubahan sosial, privasi, ketergantungan dan gaya hidup.

\section{Latihan Soal}

1. Jelaskan pengertian sehat-sakit!

2. Jelaskan hubungan sehat sakit!

3. Sebutkan faktor yang mempengaruhi status kesehatan!

4. Jelaskan tahapan proses sakit!

5. Jelaskan dampak sakit dan dirawat!

\section{Daftar Pustaka}


Hidayat, A. Aziz Alimul dan Uliyah, M. 2008. Ketrampilan Dasar Praktik Klinik untuk Kebidanan. Edisi 2. Jakarta: Salemba Medika

Uliyah, M, Wildan M., Surachmindari dan Hidayat, A. Aziz Alimul. 2012. Ketrampilan Dasar Kebidanan I (pendekatan kurikulum Berbasis Kompetensi). Surabaya: Health Books Publishing

Yuni, Natalia E Dan Oktami, Rika S. 2014. Ketrampilan Dasar Praktik Klinik Kebidanan . Yogyakarta: Nuha Medika.

Undang-Undang Kesehatan No. 23 Tahun 1992

Undang-Undang Kesehatan No. 36 Tahun 2009 


\section{BAB III \\ STRES DAN ADAPTASI}

\section{Tujuan pembelajaran:}

Mahasiswa mampu menjelaskan stres, sumber stresor macammacam stres, model stres- kesehatan, tahapan stres, reaksi tubuh, stres pada siklus kehidupan wanita, cara menilai stres, konsep adaptasi, macam-macam adaptasi, manajemen stres dan peran bidan dalam mengatasi stres

\section{A. Pengertian Stres}

Menurut Handoko (1997), stres adalah suatu kondisi ketegangan yang mempengaruhi emosi, proses berpikir dan kondisi seseorang. Stres yang terlalu besar dapat mengancam kemampuan seseorang untuk menghadapi lingkungannya.

Menurut Robbins (2001) stres diartikan sebagai suatu kondisi yang menekan keadaan psikis seseorang dalam mencapai suatu kesempatan dimana untuk mencapai kesempatan tersebut terdapat batasan atau penghalang.

\section{B. Sumber Stresor}

Sumber stresor yang dapat mempengaruhi sifat stresor, diantaranya diantaranya lingkungan, baik secara fisik, psikososial maupun spiritual. Lingkungan fisik dapat berupa fasilitas-fasilitas seperti air minum, makan, atau tempat-tempat umum sedangkan lingkungan psikososial dapat berupa suara atau sikap kesehatan atau orang yang ada disekitarnya, sedangkan lingkungan spiritual dapat berupa perubahan fisiologis dalam tubuh, seperti karena adanya operasi, obat-obatan atau lainnya. 
Selain sumber diatas stres yang dialami manusia dapat berasal dari berbagai sumber lain seperti individu sendiri, keluarga/masyarakat dan lingkungan sekitarnya. Berikut ini adalah sumber dari stres:

1. Sumber stres didalam diri sendiri, pada umumnya karena konflik yang terjadi antara keinginan dan kenyataan bebeda, seperti adanya berbagai permasalahan yang terjadi, tidak sesuai dengan dirinya dan tidak mampu mengatasinya.

2. Sumber stres didalam keluarga, ditandai dengan adanya perselisihan masalah keluarga, masalah keuangan serta adanya tujuan yang berbeda diantara keluarga, permasalahan ini akan selalu menimbulkan stres.

3. Sumber stres didalam masyarakat dan lingkungan, sumber stres ini dapat terjadi dilingkungan atau masyarakat pada umumnya, seperti lingkungan pekerjaan, hubungan social atau lingkungan fisik karena masyarakat yang ada didalamnya kurang mampu berhubungan secara interpersonal serta kurang adanya pengakuan dimasyarakat sehingga tidak berkembang.

\section{Macam-Macam stres}

1. Stres fisik

Stres fisik yaitu stres yang terjadi akibat kondisi fisik karena suhu lingkungan yang terlalu tinggi atau sangat rendah, suara yang keras/kebisingan, perubahan iklim yang ekstrim, sinar matahari atau akibat tegangan arus listrik.

2. Stres kimiawi

Stres kimiawi yaitu stres yang disebabkan akibat zat-zat kimia misalnya obat dan zat beracun asam, basa, faktor hormon atau gas dan prinsipnya karena pengaruh senyawa kimia

3. Stres mikrobiologik

Stres mikrobiologik yaitu stres yang disebabkan karena kuman, seperti adanya virus, bakteri dan parasite. 
4. Stres fisiologik

Stres fisiologik yaitu stres yang disebabkan karena terganggunya fungsi organ tubuh diantaranya gangguan dari struktur tubuh, fungsi jaringan, organ-organ lain.

5. Stres proses pertumbuhan dan perkembangan

Stres yang disebabkan karena proses pertumbuhan dan perkembangan seperti pada pubertas, perkawinan, dan proses lanjut usia .

6. Stres spiritual

Stres spiritual merupakan kondisi yang disebabkan adanya persepsi negatif terhadap nilai-nilai keagamaan

7. Stres psikis atau emosional

Stres yang disebabkan karena gangguan situasi psikologis atau ketidakmampuan kondisi psikologis untuk menyesuaikan diri seperti hubungan interpersonal, dan sosial budaya.

\section{Model Stres- Kesehatan}

Model stres kesehatan merupakan model stres yang menjelaskan terjadinya stres yang dapat mempengaruhi status kesehatan seseorang, model ini dapat terdiri dari beberapa unsur diantaranya:

1. Terjadinya stres yang mempengaruhi kesehatan seseorang Stres secara langsung baik fisiologis maupun secara psikologis yang menyebabkan pelepasan Hormon Katekolamin dan kortikosteroid menyebabkan kondisi berdebar-debar, nadi cepat, buang air kecil, susah tidur dan lain-lain

2. Kepribadian bahwa stres dipengaruhi tipe kepribadian dari masing-masing individu yang memudahkan timbulnya perubahan mekanisme koping terhadap adanya stressor yang ada.

3. Interaktif, stres dapat menyebabkan menurunnya kekebalan tubuh sehingga mudah terjadi gangguan biologis maupun psikologis, proses ini karena adanya interaksi antara faktor 
dari luar dan faktor dari dalam untuk mempertahankan keseimbangan tubuh.

4. Perilaku sehat, Stres secara tidak langsung mempengaruhi kesakitan akan tetapi dapat merubah perilaku terlebih dahulu seperti adanya peningkatan konsumsi alkohol, rokok dan lain-lain.

5. Perilaku sakit, stres mempengaruhi secara langsung kesakitan tanpa menyebabkan penyakit yang ditunjukkan adanya perilaku sakit seperti mencari bantuan pengobatan, konsultasi untuk mendapatkan solusi dari masalah yang dihadapi.

\section{E. Faktor Pengaruh Respon Terhadap Stresor}

\section{Sifat Stresor}

Sifat stresor ini dapat berupa secara tiba-tiba atau berangsur-angsur. Pada setiap individu sifat ini berbeda tergantung dari pemahaman tentang arti stresor. Sehingga berdampak juga pada mekanisme koping individu.

2. Durasi stresor

Apabila stresor yang dialami lebih lama maka respon yang dialaminya juga akan lama yang dapat mempengaruhi fungsi tubuh.

3. Jumlah Stresor

Semakin banyak stresor yang dialami pada seseorang dapat menimbulkan dampak yang besar bagi fungsi tubuh.

4. Pengalaman Masa lalu

Pengalaman masa lalu seseorang dalam menghadapi stres dapat menjadi bekal dalam menghadapi stres yang akan datang, karena sudah memiliki kemampuan untuk beradaptasi atau memiliki koping mekanisme yang lebih baik.

5. Tipe Kepribadian

Seseorang yang memiliki tipe kepribadian A lebih rentan terkena stres dibanding dengan tipe kepribadian B. Karena tipe kepribadian A 
memiliki ciri agresif, bicara cepat, kurang sabar, mudah tersinggung, mudah marah, dan lain-lain.

6. Tingkat Perkembangan

Perkembangan adaptasi seseorang dapat dibentuk oleh tingkat perkembangan. Setiap usia perkembangan akan mengalami stresor yang berbeda.

\section{F. Tahap Stres}

1. Tahap Pertama

Tahap pertama ini ditandai sesorang mampu melakukan pekerjaan dan masih merasa senang namun kemampuannya mulai berkurang, semangat bekerja besar. Tahap ini merupakan tahap stres yang paling ringan.

2. Tahap Kedua

Tahap dimana seseorang mulai merasakan letih setiap bangun tidur pagi hari yang seharusnya segar, merasa lelah, jantung berdebardebar, merasa tegang serta merasa tidak nyaman diperut.

3. Tahap Ketiga

Gejala yang dialami berlanjut semakin bertambah tldur tidak bisa nyenyak, Terganggunya buang air besar, adanya gastritis, badan merasa lemah tidak ada tenaga dan semakin dirasakannya ketegangan otot.

4. Tahap Keempat

Gejala mulai mempengaruhi pekerjaan, merasa bosan dengan segala pekerjaan yang dilakukan, kurang tanggap terhadap situsi, tidak bergairah dan terjadi penurunan konsentrasi.

5. Tahap Kelima

Gejala yang dirasakan semakin berat, semakin meningkatnya kecemasan dan ketakutan, pekerjaan ringan tidak mampu diselesaikan, semakin beratnya ganggguan saluran pencernaan dan semakin mendalam kelelahan fisik yang dialami. 


\section{Tahap Keenam}

Merupakan tahap paling tinggi dari stres, gangguan yang dialami semakin komplek adanya susah nafas, semakin kerasnya denyut jantung, takut akan kematian dan panik, bisa terjadi kolaps dan pingsan serta seluruh tubuh terasa gemetar.

\section{G. Reaksi Tubuh Terhadap Stres}

orang bisa mengalami stres karena stres bersifat umum, namun mekanisme koping setiap individu berbeda tergantung dari karakteristik masing-masing individu.

Manifestasi respon individu terhadap stres ada tiga sebagai berikut:

1. Berupa respon verbal dan psikomotor

Respon verbal diikuti emosional psikomotor merupakan respon pertama dari individu yang mengalai stres, respon ini terjadi secara spontan. Bentuk respon ini adalah ketawa, menangis, mengumpat, teriak dan lain-lain.

2. Berupa respon Psikologis

Respon ini berupa kecemasan dan kemarahan yang dapat diamati secara subyektif dan obyektif pada seseorang yang sedang mengalami stres.

3. Berupa respon kognitif

Pada orang yang mengalami stres timbul manisfestasi respon kognitif dimana seseorang memiliki pengetahuan dan pengalaman untuk menghadapi stres dengan melatih kemampuan menghindari stres, perasaan yang tidak menyenangkan ditekan. Penurunan konsentrasi, sakit kepala dan pusing terjadi pada stres pada daya pikir.

\section{H. Stres Pada Siklus Kehidupan Wanita}

Dalam siklus kehidupan perempuan bida menimbulkan berbagai masalah stres, mulai dari remaja, masa reproduksi dan masa klimakterium. 


\section{Masa remaja}

Masalah stres pada remaja ini terjadi karena terjadi peralihan dari masa anak-anak menuju dewasa, hal ini dikenal sebagai masa pubertas. Masalah stres yang dialami pada perempuan pada masa pubertas ini antara lain masalah menstruasi seperti gangguan yang timbul pada saat menstruasi (nyeri haid, haid tidak teratur dan lainlain, perubahan tanda-tanda primer dan sekunder sudah mulai ada, perubahan fisik perempuan, tumbuhnya payudara, bertambahnya berat badan dan tinggi badan serta mengalami perubahan emosional.

\section{Masa reproduksi}

Pada masa ini yang sering mengalami masalah stres berkaitan dengan kehamilan, melahirkan bayi, menyusui. Masalah kehamilan sering dialami pada masa reproduksi yang dapat menyebabkan stres adalah karena adanya pembesaran Rahim, perkembangan payudara dan pertumbuhan janin, keluhan dan ketidaknyamanan selama hamil yang apabila tidak disiapkan secara mental maka akan menimbulkan stres. Selain itu juga stres pada masa melahirkan bayi atau menghadapi persalinan, akibat rasa nyeri persalinan, kondisi janin yang dilahirkan, serta masa menyusui bisa akibat asi tidak keluar, ganguan selama meneteki dan lain-lain.

3. Masa klimakterium

Merupakan masa peralihan yang normal yang berlangsung beberapa tahun sebelum dan sesudah menopause, fase ini ada beberapa tahap seperti sebelum menopause masalah ini seiring berkaitan dengan menurunnya fungsi reproduksi, kadar estrogen mulai turun dan hormone gonadotropin mulai meningkat, menopause ini sering terjadi perubahan psikis seperti rasa kawatir perasaan me kemudian dilajutkan dengan masalah menopause yakni periode berhentinya menstruasi secara alamiah. Pada masa menopause ini sering terjadi perubahan psikis seperti rasa kawatir, perasaan tua, tidak menarik 
lagi, takut tidak bisa memenuhi kebutuhan seksual suami, rasa tertekan takut menjadi tua, dan lebih sensitive dan emosi. Selain itu juga mengalami masalah fisik seperti kulit menjadi kendor, kering dan keriput, mudah terbakar sinar matahari, timbul pigmentasia, payudara mulai lembek, vagina menjadi kering, dyspareunia dan lain sebagainya. Pasca menopause kadar estrogen pada titik rendah dan juga terjadi kemunduran alat tubuh seperti cenderung terjadi osteoporosis yang disebabkan oleh pengaruh hormone steroid dan osteotrofoblast yang berkurang.

\section{Cara Menilai Stres}

Tingkat stres dapat dikelompokkan dengan menggunakan kriteria HARS (Hamilton Anxiety Rating Scale). Unsur yang dinilai antara lain: perasaan ansietas, ketegangan, ketakutan, gangguan tidur, gangguan kecerdasan, perasaan depresi, gejala somatik, gejala respirasi, gejala gejala kardiovaskuler, gejala respirasi, gejala gastrointestinal, gejala urinaria, gejala otonom, gejala tingkah laku. Unsur yang dinilai dapat menggunakan skoring, dengan ketentuan penilaian sebagai berikut:

0 : Tidak ada gejala dari pilihan yang ada

1: Satu gejala dari pilihan yang ada

2: Kurang dari separuh dari pilihan yang ada

3: Separuh atau lebih dari pilihan yang ada

4: Semua gejala ada

Untuk selanjutnya skor yang dicapai dari masing-masing unsur atau item dijumlahkan sebagai indikasi penilaian derajat stres, dengan ketentuan sebagai berikut:

- Bila didapatkan skor < 14 kategori tidak ada stres

- Bila didapatkan Skor 14-20 kategori stres ringan

- Bila didapatkan Skor 21-27 kategori stres sedang

- Bila didapatkan Skor 28-41 kategori stres berat

- Bila didapatkan Skor 42-56 kategori stres berat sekali 
Komponen penilaian dari HARS (Hamilton Anxiety Rating Scale) adalah sebagai berikut

\begin{tabular}{|c|c|c|}
\hline NO & Gejala & Skor \\
\hline \multirow[t]{5}{*}{1} & Perasaan cemas & \\
\hline & a. Firasat buruk & \\
\hline & b. Takut akan pikiran sendiri & \\
\hline & c. Mudah tersinggung & \\
\hline & d. Muda emosi & \\
\hline \multirow[t]{6}{*}{2} & Ketegangan & \\
\hline & a. Merasa tegang & \\
\hline & b. Lesu & \\
\hline & c. Mudah terkejut & \\
\hline & d. Tidak dapat istirahat dengan tenang & \\
\hline & e. Mudah menangis, gemetar, gelisah & \\
\hline \multirow[t]{5}{*}{3} & Ketakutan & \\
\hline & a. Pada gelap & \\
\hline & b. Ditinggal sendiri & \\
\hline & c. Pada orang asing & \\
\hline & d. Pada kerumunan banyak orang & \\
\hline \multirow[t]{5}{*}{4} & Gangguan Tidur & \\
\hline & a. Sukar memulai tidur & \\
\hline & b. Terbangun malam hari & \\
\hline & c. Mimpi buruk & \\
\hline & d. Mimpi yang menakutkan & \\
\hline \multirow[t]{5}{*}{5} & Gangguan kecerdasan & \\
\hline & a. Daya ingat buruk & \\
\hline & b. Sulit berkonsentrasi & \\
\hline & c. Sering bingung & \\
\hline & d. Banyak pertimbangan & \\
\hline
\end{tabular}




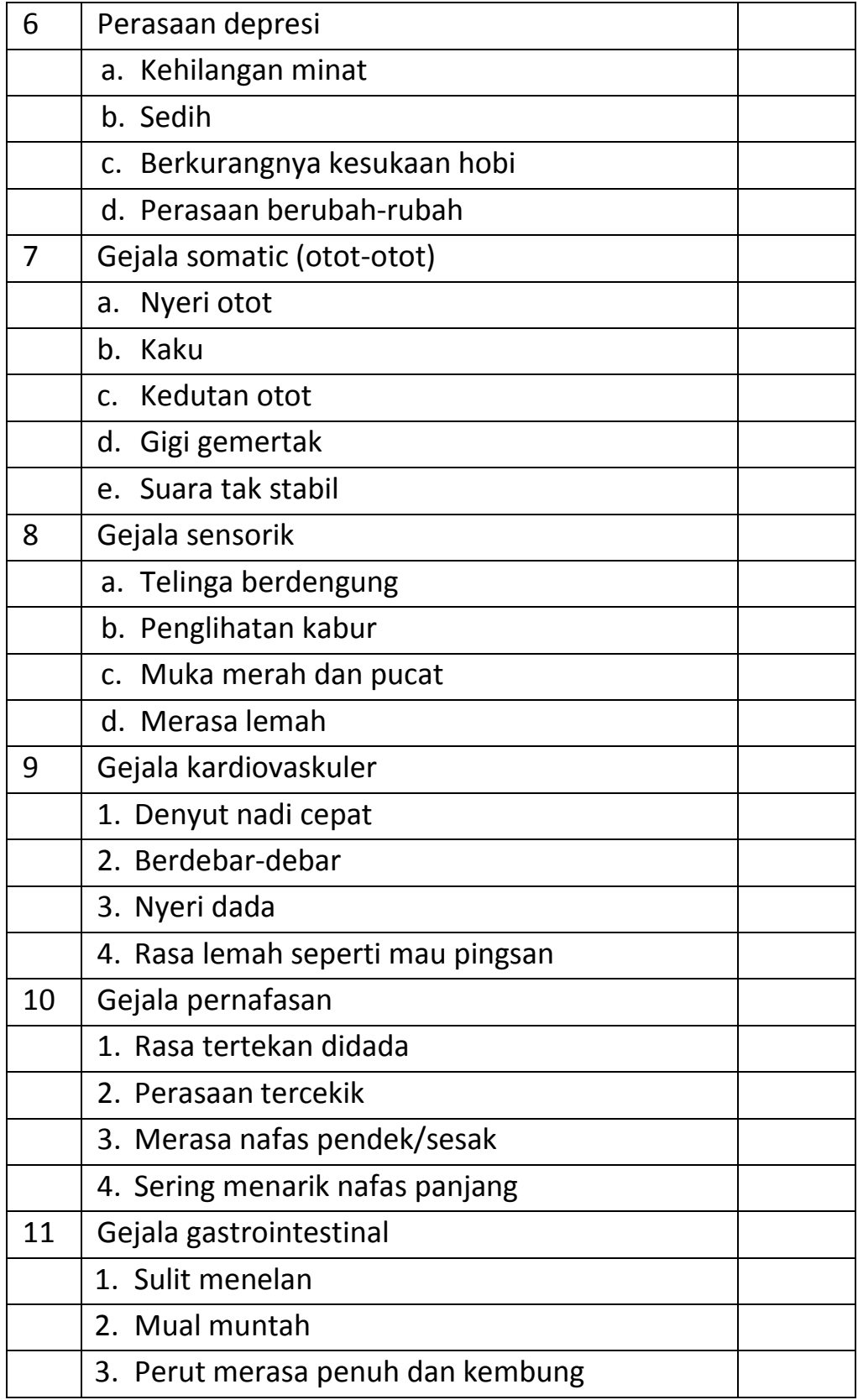




\begin{tabular}{|l|l|l|}
\hline & $\begin{array}{l}\text { 4. Nyeri lambung sebelum makan dan sesudah } \\
\text { makan }\end{array}$ & \\
\hline 12 & Gejala urogenital & \\
\hline & 1. Sering kencing & \\
\hline 13 & 2. Tidak dapat menahan kencing & \\
\hline & Gejala otonom & \\
\hline & b. Mulut kering & \\
\hline & c. Mudah bering & \\
\hline & d. Sakit kepala & \\
\hline & e. Bulu roma berdiri & \\
\hline 14 & Apakah anda merasakan & \\
\hline & 1. Gelisah & \\
\hline & 2. Tidak tenang & \\
\hline & 3. Mengerutkan dahi muka tegang & \\
\hline & 4. Nafas pendek dan cepat & \\
\hline
\end{tabular}

\section{J. Konsep Adaptasi}

Adaptasi merupakan suatu proses perubahan yang mengikuti individu untuk merespon terhadap perubahan diingkungan yang dapat mempengaruhi keutuhan tubuh baik secara fisiologis maupun psikologis yang menghasilkan perilaku adaptif. Hasil dari perilaku adaptif ini dapat berupa semua respon yang selalu berusaha mempertahankan keseimbangan dari suatu keadaan.

\section{K. Macam-macam Adaptasi}

\section{Adaptasi fisiologi}

Merupakan suatu proses penyesuaian tubuh secara alamiah atau fisiologis untuk mempertahankan keseimbangan dari berbagai faktor yang menimbulkan atau mempengaruhi keadaan tidak seimbang. 
Contoh dari adaptasi fisiologi adalah pada saat mikroorganisme masuk kedalam tubuh maka secara fisiologis tubuh akan bereaksi dan berusaha untuk mempertahankan baik dari pintu masuknya kuman atau sudah masuk dalam tubuh.

Proses adaptasi fisiologi bisa secara lokal dan umum.

Adaptasi lokal (lokal adaptation syndrome) hal ini seperti bila pada kulit terkena infeksi maka di area kulit bisa kemerahan, bengkak, nyeri, panas dan lain-lain.

Adaptasi umum atau sistemik (General Adaptation Syndrom) merupakan suatu proses adaptasi yang terjadi akibat adaptasi lokal tidak berhasil sehingga mengakibatkan gangguan sistem atau seluruh tubuh, berkeringat dan lain-lain.

\section{Ada tiga tahap adaptasi fisiologi}

a. Tahap arm reaction (tahap awal)

Tahap individu siap menghadapi stresor yang masuk ke dalam tubuh, ditandai dengan keluarnya hormone oleh hipotalamus yang mengakibatkan kelenjar adrenal mengeluarkan adrenalin sehingga denyut jantung dan nafas menjadi cepat.

b. Stage of resistensi (tahap resisten)

Merupakan tahap kedua dimana tubuh akan melakukan proses penyesuaian dengan mengadakan berbagai perubahan dalam tubuh dengan berusaha untuk mengatasi stresor yang ada, seperti jantung yang bekerja lebih keras untuk mendorong darah yang pekat untuk melewati arteri dan vena yang menyempit.

c. Stage of exhaustion (tahap terakhir)

Tahap akhir ini ditandai dengan adanya kelelahan jika selama proses adaptasi tidak mampu mengatasi stresor yang ada maka dapat menyebar keseluruh tubuh efeknya dapat menyebabkan kematian tergantung dari stresor yang ada.

\section{Adaptasi Psikologis}


Merupakan proses penyesuaian secara psikologis dengan cara memberikan mekanisme pertahanan diri yang bertujuan untuk melindungi atau bertahan dari serangan-serangan atau hal-hal yang tidak menyenangkan.

Proses adaptasi psikologis melalui 2 cara yaitu:

a. Reaksi berorientasi pada tugas (Task oriented reaction) Merupakan koping yang digunakan dalam mengatasi masalah berorientasi pada problem solving. Bentuk reaksi ini bisa berupa menyampaikan masalah kepada orang lain untuk mencari solusi, melakukan latihan yang dapat mengatasi stres serta menggunakan strategi pemecahan masalah dengan skala prioritas.

\section{b. Reaksi orientasi pada ego (Ego oriented reaction)}

Reaksi dengan menggunakan mekanisme pertahanan diri secara psikologik dengan tujuan agar tidak terjadi gangguan psikologi yang lebih dalam. Mekanisme pertahanan diri antara lain :

1) Rasionalisasi

Suatu usaha untuk menghindari masalah dengan memberikan alasan secara rasional, sehingga masalah bisa teratasi.

2) Displacement

Suatu upaya untuk mengatasi masalah dengan melakukan pemindahan tingkah laku pada obyek lain, apabila seseorang terganggu akibat situasi yang ramai maka temannya disalahkan.

3) Kompensasi

Suatu upaya untuk mengatasi masalah dengan mencari kepuasaan pada keadaan, seperti seseorang yang memiliki masalah karena menurunnya daya ingat, disisi lain bakat yang ditonjolkan.

4) Proyeksi

Mekanisme pertahanan diri dengan menempatkan sifat batin sendiri kedalam sifat batin orang lain, seperti dirinya membenci orang lain kemudian mengatakan pada orang bahwa orang lain yang membencinya. 


\section{5) Represi}

Mengatasi masalah dengan menghilangkan pikiran masa lalu yang buruk dengan melupakan atau menahan ke alam tidak sadar dan sengaja masalah tersebut dilupakan.

6) Supresi

Mengatasi masalah dengan menekan masalah yang tidak diterima dengan sadar dan individu tidak mau memikirkan hal-hal yang kurang menyenangkan.

7) Denial

Upaya pertahanan diri dengan cara penolakan terhadap masalah yang dihadapi atau tidak mau menerima kenyataan yang dihadapinya.

\section{c. Adaptasi Sosial Budaya}

Suatu upaya untuk melakukan perubahan perilaku dengan melaksanakan proses penyesuaian perilaku sesuai dengan norma yang berlaku dimasyarakat seperti berkumpul dengan masyarakat untuk melakukan kegiatan kemasyarakatan.

\section{d. Adaptasi Spiritual}

Adaptasi dengan melaksanakan perubahan perilaku berdasarkan pada keyakinan atau kepercayaan yang dimiliki sesuai dengan agama yang dianutnya, jika mengalami stres maka seseorang akan lebih mendekatkan diri pada yang maha kuasa misalnya dengan rajin beribadah.

\section{Manajemen Stres}

Merupakan suatu tindakan yang dilakukan dalam mengelola masalah stres dengan baik yang bertujuan untuk mencegah dan mengatasi stres agar tidak berlanjut ke tahap yang berat.

Ada beberapa manajemen stres yang bisa dilakukan antara lain:

1. Pengaturan Diet dan Nutrisi

Mengatur makanan dan minuman yang dikonsumsi, makan makanan yang halal, tidak makan secara berlebihan dan memenuhi gizi seimbang dan bervariasi. Minum air putih yang cukup. 
2. Istirahat dan Tidur

Kebutuhan Istirahat dan tidur yang terpenuhi dapat mengembalikan kondisi tubuh kembali segar dari kelelahan fisik dan sel-sel tubuh yang rusak mengalmi perbaikan.

3. Olahraga atau Latihan Teratur

Melakukan olah raga atau latihan secara teratur dengan melakukan jalan di pagi hari, lari atau senam dapat meningkatkan sistem kekebalan tubuh dan kesehatan mental.

4. Berhenti Merokok

Merokok dapat mengganggu kesehatan, dengan berhenti merokok dapat menjaga kesehatan dan kekebalan tubuh.

5. Tidak Mengkonsumsi minuman Keras

Minum-minuman keras dapat menyebabkan berbagai gannguan kesehatan akibat kandungan alkohol yang ada didalamnya. Tidak mengkonsumsi minuman keras kesehatan dan kekebalan tubuh terjaga.

6. Pengaturan Berat Badan

Berat badan yang meningkat bisa mengakibatkan terjadinya stres, Stres memicu hormon kotekalamin meningkat dan bisa menurunkan sistem kekebalan tubuh.

7. Pengaturan waktu

Dengan mengatur waktu, semua jenis pekerjaan yang dapat mengakibat keletihan fisik dapat dicegah. Keletihan fisik dapat menurunkan sistem kekebalan tubuh.

8. Terapi Psikofarmaka

Memberikan obat-obatan untuk penanganan stres, dengan cara kerja menghentingkan sel jaringan psiko neuro dan imunologi sehingga stresor psikososial tidak berpengaruh terhadap fungsi kognitif, afektif atau psikomotor yang dapat menyebabkan gangguan pada organ tubuh lain.

9. Terapi Somatik

Pengobatan terhadap gejala fisik yang disebabkan oleh stres, sehingga tidak berdampak pada sistem tubuh yang lain. Misalnya 
sakit kepala akibat stres maka diberikan obat analgetik untuk mengatasi sakit kepala tersebut.

10. Psikoterapi

Pengobatan yang dilakukan dengan memberikan dukungan, motivasi dan pendidikan untuk mengatasi stres, baik dilakukan sekali atau secara berulang-ulang.

11. Terapi Psikoreligius

Pengobatan yang dilakukan dengan berorientasi pada agama atau keyakinan dalam mengatasi masalah akibat stres. Sehat tidak hanya secara fisik maupun psikologis tetapi secara sosial dan spiritual.

\section{Peran Bidan Dalam Mengatasi Stres}

Ada beberapa hal yang dilakukan oleh bidan antara lain :

1. Seorang bidan harus mampu menfasilitasi adanya permasalahan seseorang yang mengalami stres

2. Dalam melaksanakan tindakan bidan melakukan tindakan manajemen stres sesuai dengan prinsip manajemen stres

3. Bidan dapat menggunakan strategi pemecahan masalah yang bertujuan mengurangi adanya stres secara efektif untuk jangka yang panjang dapat meningkatkan keyakinan diri dan kemampuan dalam menghadapi dan memecahkan masalah yang akan datang.

\section{Kesimpulan}

1. Stres diartikan sebagai suatu kondisi yang menekan keadaan psikis seseorang dalam mencapai suatu kesempatan dimana untuk mencapai kesempatan tersebut terdapat batasan atau penghalang.

2. Sumber stresor individu sendiri, keluarga/masyarakat dan lingkungan sekitarnya.

3. Macam-macam stres antara lain stres fisik, kimiawi, mikrobiologik, fisiologik, pertumbuhan dan perkembangan, spiritual, psikis atau emosional.

6. Model stres mempengaruhi kesehatan seseorang 
Stres secara langsung baik fisiologis maupun psikologis yang menyebabkan pelepasan Hormon Katekolamin dan kortikosteroid menyebabkan kondidsi berdebar-debar, nadi cepat dan lain-lain

4. Faktor pengaruh respon terhadap stresor tergantung dari sifat, durasi, jumlah stresor, pengalaman masa lalu, tipe kepribadian dan tingkat perkembangan.

5. Ada 6 tahapan stress mulai dari stres ringan sampai terjadi gangguan yang kompleks.

6. Reaksi tubuh terhadap stres bisa berupa respon verbal. psikomotor, psikologis dan kognitif.

7. Stres pada siklus kehidupan wanita terjadi pada masa remaja, reproduksi dan klimakterium.

8. Cara menilai stres dapat menggunakan kriteria HARS (Hamilton Anxiety Rating Scale) mulai dari tidak ada stres, stres ringan, sedang, berat dan berat sekali

9. Adaptasi merupakan suatu proses perubahan yang mengikuti individu untuk merespon terhadap perubahan diingkungan yang dapat mempengaruhi keutuhan tubuh baik secara fisiologis maupun psikologis yang menghasilkan perilaku adaptif.

10. Macam-macam adaptasi ada 4 yaitu fisiologis, psikologis, sosial budaya dan spiritual.

11. Beberapa manajemen stres yang bisa dilakukan yaitu pengaturan diet, istirahat tidur, olahraga, berhenti merokok, tidak konsumsi alkohol, pengaturan berat badan, pengaturan waktu, terapi psikofarmaka, somatik, psikoterapi dan terapi religius.

12. Peran bidan dalam mengatasi stres mulai dari mengkaji masalah yang menyebabkan stres sampai menggunakan strategi yang efektif untuk mengurangi stres.

\section{Latihan Soal}

1. Jelaskan pengertian Stres !

2. Apa saja sumber stresor itu? 
3. Jelaskan macam-macam stres!

4. Jelaskan model Stres- Kesehatan!

5. Apa saja faktor pengaruh respon terhadap stresor?

6. Jelaskan tahapan Stres!

7. Jelaskan reaksi tubuh terhadap stres!

8. Jelaskan stres pada siklus kehidupan wanita!

9. Bagaimana cara Menilai Stres?

10. Jelaskan konsep adaptasi!

11. Sebutkan macam-macam adaptasi!

12. Apa saja yang bias dilakukan dalam manajemen stres?

13. Jelaskan peran bidan dalam mengatasi stres!

\section{Daftar Pustaka}

Hidayat, A. Aziz Alimul dan Uliyah, M. 2008. Ketrampilan Dasar Praktik Klinik untuk Kebidanan. Edisi 2. Jakarta: Salemba Medika

Uliyah,M, Wildan M., Surachmindari dan Hidayat, A. Aziz Alimul. 2012. Ketrampilan Dasar Kebidanan I (pendekatan kurikulum Berbasis Kompetensi). Surabaya: Health Books Publishing

Yuni, Natalia E Dan Oktami, Rika S. 2014. Ketrampilan Dasar Praktik Klinik Kebidanan . Yogyakarta: Nuha Medika 


\section{BAB IV \\ KESELAMATAN PASIEN (PATIENT SAFETY) DAN \\ PENCEGAHAN DAN INFEKSI}

\section{Tujuan pembelajaran :}

Mahasiswa mampu menguasai teori dan mampu menerapkan keselamatan pasien dan pencegahan infeksi.

\section{A. Keselamatan Pasien (Patient safety)}

\section{Pengertian}

Keselamatan pasien (Patien safety) Adalah disiplin ilmu di sektor perawatan kesehatan yang menerapkan metode ilmu keselamatan menuju tujuan mencapai sistem penyampaian layanan kesehatan yang dapat dipercaya. Keselamatan pasien juga merupakan atribut sistem perawatan kesehatan; Ini meminimalkan kejadian dan dampak, dan memaksimalkan pemulihan dari efek samping (Emanuel, 2008)

Vincent (2008), keselamatan pasien didefinisikan sebagai penghindaran, pencegahan dan perbaikan dari hasil tindakan yang buruk atau injuri yang berasal dari proses perawatan kesehatan.

Keselamatan pasien adalah suatu sistem yang membuat asuhan pasien lebih aman, meliputi assesmen risiko, identifikasi dan pengelolaan risiko pasien, pelaporan dan analisis insiden, kemampuan belajar dari insiden dan tindak lanjutnya, serta implementasi solusi untuk meminimalkan timbulnya risiko dan mencegah terjadinya cedera yang disebabkan oleh kesalahan akibat melaksanakan suatu tindakan atau tidak mengambil tindakan yang seharusnya diambil (PMK NO. 11 Tahun 2020). 


\section{Istilah insiden keselamatan pasien yang telah dikenal secara}

luas berikut definisinya yaitu:

a. Insiden Keselamatan Pasien (IKP) / Patient Safety Incident yaitu setiap kejadian / situasi yang dapat mengakibatkan atau berpotensi mengakibatkan harm (penyakit, cedera, cacat, kematian dan lain-lain) yang tidak seharusnya terjadi.

b. Kejadian Tidak Diharapkan (KTD) / Adverse Event yaitu suatu kejadian yang mengakibatkan cedera yang tidak diharapkan karena suatu tindakan ("commission") atau karena tidak bertindak ("omission"), bukan karena "underlying disease" atau kondisi pasien.

c. Kejadian Nyaris Cedera (KNC) / Near Miss yaitu suatu insiden yang belum sampai terpapar ke pasien sehingga pasien tidak cedera.

d. Kejadian Tidak Cedera (KTC) yaitu insiden sudah terpapar ke pasien, tidak menimbulkan cedera, dapat terjadi karena "keberuntungan" (misal: pasien terima suatu obat kontra indikasi tetapi tidak timbul reaksi obat), atau "peringanan" (suatu obat dengan reaksi alergi diberikan , diketahui secara dini lalu diberikan antidotumnya).

e. Kondisi Potensial Cedera (KPC) / "reportable circumstance" yaitu kondisi yang sangat berpotensi cedera, tetapi belum terjadi insiden.

f. Kejadian Sentinel (Sentinel Event) yaitu suatu KTD yang mengakibatkan kematian atau cedera yang diharapkan atau tidak dapat diterima seperti: operasi pada bagian tubuh yang salah. Pemilihan kata "sentinel" terkait dengan keseriusan cedera yang terjadi (misalnya Amputasi pada kaki yang salah, dan sebagainya) sehingga pencarian fakta terhadap kejadian ini mengungkapkan adanya masalah yang serius pada kebijakan dan prosedur yang berlaku. 


\section{Model patient safety}

Vincent (2010) menawarkan model sederhana berikut untuk melihat keselamatan pasien. Ini membagi sistem perawatan kesehatan menjadi empat domain:

a. Mereka yang bekerja di bidang kesehatan

b. Mereka yang mendapat perawatan kesehatan atau memiliki saham dalam ketersediaannya

c. Infrastruktur sistem untuk intervensi terapeutik (proses pemberian layanan kesehatan)

d. Metode umpan balik dan perbaikan terus menerus

\section{Standar patient safety}

a. Hak pasien

b. Mendidik pasien dan keluarga

c. Keselamatan pasien dan kesinambungan pelayanan.

d. Penggunaan metoda-metoda peningkatan kinerja untuk melakukan evaluasi dan program peningkatan keselamatan pasien

e. Peran kepemimpinan dalam meningkatkan keselamatan pasien

f. Mendidik staf tentang keselamatan pasien

g. Komunikasi merupakan kunci bagi staf untuk mencapai keselamatan pasien

5. Langkah menuju patient safety

a. Bangun budaya keselamatan

b. Pimpin dan dukung staf anda

c. Integrasikan kegiatan manajemen risiko anda

d. Bangun sistem pelaporan

e. Libatkan dan berkomunikasi dengan pasien dan masyarakat

f. Belajar dan berbagi tentang pembelajaran keselamatan

g. Implementasikan solusi-solusi untuk mencegah cidera 


\section{Penerapan Sembilan Solusi Keselamatan Pasien Rumah}

Sakit.

a. Perhatikan Nama Obat, Rupa dan Ucapan Mirip (NORUM/Look-Alike, Sound-Alike Medication Names/LASA).

Sound-Alike
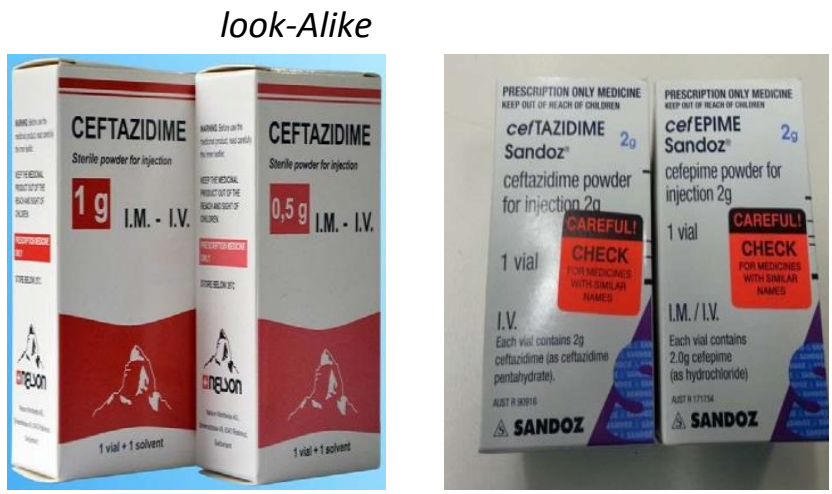

Gb. 4.1 Contoh obat NORUM/LASA

Sumber: https://spo-keperawatan.blogspot.com

L2016/06/spo-pengelolaan-obat-lasa.html

b. Pastikan Identfikasi Pasien.

- Semua pasien harus diidentifikasi dengan benar mulai dari pendaftaran sampai dengan pasien pulang

- Sebelum memberikan layanan (pemberian obat, darah, produk darah, pemberian diet khusus tersaji di baki (penampan), atau pemberian radio terapi.

- Sebelum tindakan (seperti menerima cairan intravenous atau hemodialisis).

- Sebelum dilakukan setiap tindakan prosedur diagnostik (seperti pengambilan darah atau 
pengambilan spesimen lain untuk pemeriksaaan klinik, katerisasi jantung, atau prosedur radiologi diagnostic

Alat Identifikasi : Karcis, gelang identitas, id card, label Ada beberapa warna gelang sebagai identifikasi

- Warna merah muda : jenis kelamin wanita

- Warna biru : untuk jenis kelamin laki-laki

- Warna merah : untuk pasien yang alergi obat

- Warna putih : Untuk berjenis kelamin ganda

- Warna kuning : untuk pasien yang mempunyai risiko jatuh

- Warna hijau : untuk pasien yang alergi lateks

- Warna abu-abu : untuk pasien yang dilakukan kemoterapi

- Warna ungu : DNR (Do Not Resuscitation) pasien yang memiliki harapan hidup rendah.

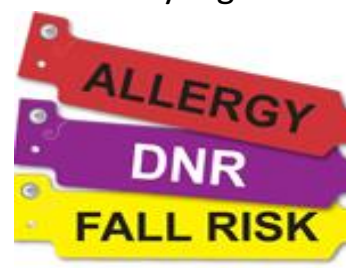

Gambar: 4.2 Contoh gelang identifikasi

Sumber:http://identitaspasien.arata.co.id/produk/gelang-pasien/

Cara Identifikasi Pasien

Identifikasi menggunakan minimal 2 data identitas yaitu:

- Nama pasie dan nomor rekam medis (No.RM)

- Nama pasien dan tanggal lahir

- Nama pasien dan nama ibu kandung

Dilarang identifikasi dengan nomor kamar pasien/lokasi 
c. Menyampaikan dengan tepat pada saat serah terima pasien

Penyampaian informasi yang tidak tepat bisa mengkibatkan terganggunya kesinambungan layanan, salah pengobatan dan risiko cidera, untuk menghindari kejadian tersebut perlu standar komunikasi misalnya menggunakan SBAR (situasi, background, assessment dan recommendation)

d. Memastikan tindakan yang benar pada sisi tubuh yang benar

Penyimpangan ini seharusnya dapat dicegah. Kasus-kasus dengan pelaksanaan prosedur yang keliru atau pembedahan sisi tubuh yang salah sebagian besar adalah akibat dan miskomunikasi dan tidak adanya informasi atau informasinya tidak benar. Faktor yang paling banyak kontribusinya terhadap kesalahan macam ini adalah tidak ada atau kurangnya proses pra-bedah yang distandardisasi. Rekomendasinya adalah untuk mencegah jenis-jenis kekeliruan yang tergantung pada pelaksanaan proses verifikasi prapembedahan; pemberian tanda pada sisi yang akan dibedah oleh petugas yang akan melaksanakan prosedur; dan adanya tim yang terlibat dalam prosedur, sesaat sebelum memulai prosedur untuk mengkonfirmasikan identitas pasien, prosedur dan sisi yang akan dibedah.

Contoh : penandaan lokasi operasi pada lokasi tubuh yang ada lateralisasi dan adanya sign in, time out, dan sign out.

e. Mengatur konsentrasi cairan elektolit yang pekat.

Sementara semua obat-obatan, biologis, vaksin dan media kontras memiliki profil risiko, cairan elektrolit pekat yang digunakan untuk injeksi khususnya adalah berbahaya. Rekomendasinya adalah membuat standarisasi dari dosis, unit ukuran dan istilah; dan pencegahan atas penyimpanan, pelabelan dan pengenceran cairan elektrolit pekat yang spesifik. 
Contoh : penyimpanan elektrolit pekat, pemberian label high allert, instruksi yang jelas untuk pengenceran, SPO pemberian obat high allert dengan double check

f. Memastikan ketepatan pemberian obat pada saat transisi pelayanan maka untuk menghindari kesalahan dalam menuliskan perintah medikasi dan komunikasi daftar obat kepetugas layanan yang berikutnya dimana pasien akan ditranfer perlu adanya formulir transfer pasien pada rekam medis yang berisi catatan tentang obat yang diberikan bila pasien dipindahkan keruangan rawat lain/ transfer .

g. Mencegah kesalahan memasang kateter dan salah sambung selang

Untuk mencegah kesalahan pemasangan kateter yang bisa menyebabkan cidera dalam perawatan pasien maka perlu dibuat standar operasional pemasangan kateter, Naso gastic tube (NGT)

h. Memakai spuit disposable

Penggunaan spuit disposable atau sekali pakai direkomendasikan untuk mencegah penyebaran penyakit HIV.HBV dan HCV. Harus dibuat kebjakan pemakaian jarum suntik sekali pakai.

i. Tingkatkan kebersihan tangan (hand hygiene) untuk pencegahan infeksi.

Diperkirakan bahwa pada setiap saat lebih dari 1,4 juta orang di seluruh dunia menderita infeksi yang diperoleh di rumah-sakit. Kebersihan tangan yang efektif adalah ukuran preventif yang primer untuk menghindarkan masalah ini. Rekomendasinya adalah mendorong implementasi penggunaan cairan, seperti alkohol, handrubs, dan sebagainya. Yang disediakan pada titik-titik pelayanan tersedianya sumber air pada semua kran, pendidikan staf mengenai teknik kebersihan tangan yang benar, mengingatkan penggunaan tangan bersih ditempat kerja; dan pengukuran kepatuhan penerapan 
kebersihan tangan melalui pemantauan/ observasi dan tehnik yang lain.

Contoh: Kebijakan dan SPO tentang hand hygiene

\section{B. Pencegahan Infeksi}

\section{Sejarah Dan dasar pelaksanaan kewaspadaan universal} Karena munculnya HIV/AIDS 1985 untuk melindungi petugas dari infeksi tersebuat dibuat pedoman universal Precaution.

Penyakit infeksi terkait pelayanan kesehatan /Healthcare Associated Infection (HAls) salah satu masalah kesehatan diberbagai negara didunia, termasuk di Indonesia. Pada prinsipnya fasilitas kesehatan dapat mencegah penyakit infeksi terkait pelayanan kesehatan jika fasilitas kesehatan tersebut secara konsisten menerapkan tindakan pencegahan dan pengendalian infeksi(PPI)

Center for desease control and prevention (CDC) dan HICPAC tahun 2007 merekomendasikan 11 (sebelas) komponen utama yang harus dilaksanakan dan dipatuhi dalam kewaspadaan standar, yaitu :

1. Kebersihan tangan,

2. Alat Pelindung Diri (APD),

3. Dekontaminasi peralatan perawatan pasien,

4. Kesehatan lingkungan,

5. Pengelolaan limbah,

6. Penatalaksanaan linen,

7. Perlindungan kesehatan petugas,

8. Penempatan pasien,

9. hygiene respirasi/etika batuk dan bersin,

10. praktik menyuntik yang aman dan

11. praktik lumbal pungsi yang aman.

\section{Pengenalan lingkungan fisik dalam pelayanan kebidanan}

Semua yang ada dilingkungan dan terlibat dalam interaksi individu pada waktu melakukan aktifitasnya 
Lingkungan fisik terdiri dari semua benda-benda mati yang berada disekitar bisa berupa bangunan, tempat tinggal dan lain-lain. Lingkungan fisik dalam pelayanan kebidanan Rumah sakit, Klinik, puskesmas, Praktik mandiri bidan dan pelayanan di komunitas.

\section{Prinsip dalam pencegahan infeksi}

\section{a. Transmisi kuman}

Sebuah proses masuknya kuman kedalam tubuh seseorang yang menimbulkan sebuah keradangan atau penyakit dalam tubuh. Proses ini melibatkan beberapa unsur, diantaranya Agen, reservoir, jalan masuk, host, jalan keluar dari resevoir, dan saluran penyebaran.

1) Reservoir yaitu suatu habitat, tempat untuk pertumbuhan dan perkembangan mikroorganisme, dapat berupa manusia, binatang, tumbuhan, ataupun tanah

2) Jalan masuk yaitu jalan masuknya microorganisme ke tempat penampungan dari berbagai kuman, seperti sistem tubuh manusia (saluran pernafasan, pencernaan, kulit dan lain-lain)

3) Host (inang) yaitu tempat berkembangnya suatu mikroorganisme, yang dapat didukung oleh ketahanan kuman.

4) Jalan keluar yaitu tempat keluarnya mikroorganisme dari reservoir seperti sistem pernafasan, sistem pencernaan, alat kelamin dan lain-lain.

5) Saluran penyebaran yaitu saluran yang dapat menyebarkan berbagai kuman mikroorganisme ke berbagai tempat, seperti air, makanan, udara dan lain-lain.

\section{b. Cara penularan}

Transmisi mikroorganisme dapat terjadi dengan berbagai cara, bisa lebih dari satu cara. Ada lima cara terjadinya trasmisi mikroorganisme yaitu: 
1) Contact transmission pada infeksi nosokomial, dibagi 2 direct \& indirect contact.

a) Direct contact (kontak langsung) : langsung ke permukaan tubuh, seperti saat memandikan, membalikkan pasien, kegiatan asuhan keperawatan yang menyentuh permukaan tubuh pasien, dapat juga terjadi di antara dua pasien.

b) Indirect contact (kontak tidak langsung): melalui peralatan yang terkontaminasi, seperti peralatan instrument yang terkontaminasi : jarum, alat dressing, tangan yang terkontaminasi tidak dicuci, dan sarung tangan tidak diganti di antara

2) Droplet transmission (Percikan)

a) Mekanisme transfer mikroorganisme pathogen ke pejamu agak ada jarak dari transmisi kontak. Mempunyai partikel sama atau lebih besar dari 5 mikron. Terjadi ketika batuk, bersin, beribicara, dan saat melakukan tindakan khusus, seperti saat melakukan pengisapan lendir, dan tindakan broschoskopi.

b) Karena droplet tidak meninggalkan sisa di udara, maka penangan khusus udara dan ventilasi tidak diperlukan untuk mencegah droplet transmisi.

3)Airbone transimisi (melalui udara)

a) Melalui udara yang terkontaminasi dengan mikroorganisme pathogen, memiliki partikel kurang atau sama dengan 5 mikron.

b) Terjadi ketika menghirup udara yang mengandung mikroorganisme pathogen.

c) Mikroorganisme dapat tinggal di udara beberapa waktu sehingga penanganan khusus udara dan ventilasi perlu dilakukan.

d) Contoh mycrobacterium tubercolusis, rubeola, dan varicella virus. 
4) Common Vehicle Transmission

Transmisi mikroorganisme melalui makanan, minuman, alat kesehatan, dan peralatan lain yang terkontaminasi dengan mikroorganisme pathogen.

5) Vectorborne transmission

Transmisi mikroorganisme melalui vector seperti nyamuk, lalat, tikus, serangga lainya.

\section{c. Faktor yang mempengaruhi proses infeksi}

1) Infeksipenyakit

Merupakan sumber penyakit yang dapat mempengaruhi apakah infeksi berjalan cepat atau lambat

2) Kuman penyebab sumber di kuman

Kuman penyebab dapat menentukan jumlah mikroorganisme, kemampuan mikroorganisme kedalam tubuh dan virulensinya.

3) Cara membebaskan sumber dari kuman

Cara membebaskan kuman dapat menentukan apakah proses infeksi dapat cepat teratasi atau diperlambat, seperti tingkat keasaman $(\mathrm{PH})$ suhu, penyinaran (cahaya) dan lain-lain.

4) Cara penularan

Cara penularan seperti kontak langsung melalui makanan atau udara dapat menyebabkan penyebaran kuman ke dalam tubuh.

5) Cara masuknya kuman

Proses penyebaran kuman berbeda, bergantung dari sifatnya. Kuman dapat masuk melalui saluran pernafasan, saluran pencernaan dan lain-lain.

6) Daya tahan tubuh

Daya tahan tubuh yang baik dapat memperlambat proses infeksi atau mempercepat penyembuhan. Dan sebaliknya daya tahan yang buruk dapat memperburuk proses infeksi.

7) Status gizi

Status gizi yang baik bisa menghambat proses infeksi sedangkan status gisi yang buruk rentan terhadap terjadinya infeksi. 
8) Tingkat stres

Tingkat stres akan menurunkan imun sehingga daya tahan tubuh menurun dan bisa menimbulkan rentan terjadi infeksi.

9) Faktor usia Usia bayi anak danlanjut usia rentan terjadi infeksi, pada bayi dan anak kondisi fisik belum matang sedangkan pada lanjut usia terjadi penurunan fungsi organ.

10) Kebiasaan yang kurang sehat

Kebiasaan hidup yang kurang sehat menyebabkan mudah terkena infeksi.

\section{d. Tindakan Pencegahan Infeksi}

(Mencuci Tangan, APD, Teknik Aseptik, Pemrosesan Alat dan Pengelolahan Sampah

1) Mencuci tangan

Merupakan sebagai suatu tindakan untuk mencegah infeksi dan menurunkan jumlah mikroorganisme yang ada pada permukaan kulit pada kedua belah tangan.

Pencucian ini bertujuan untuk menghilangkan kotoran dan debu secara mekanis dari permukaan kulit dan mengurangi jumlah mikroorganisme sementara.

Mencuci tangan dengan air mengalir dan sabun dilakukan bila tangan tampak kotor dan lama mencuci 40-60 detik. Sedangkan menggunakan handrub bila tangan tidak tampak kotor, menggunakan antiseptic alkohol lamanya 20-30 detik. 


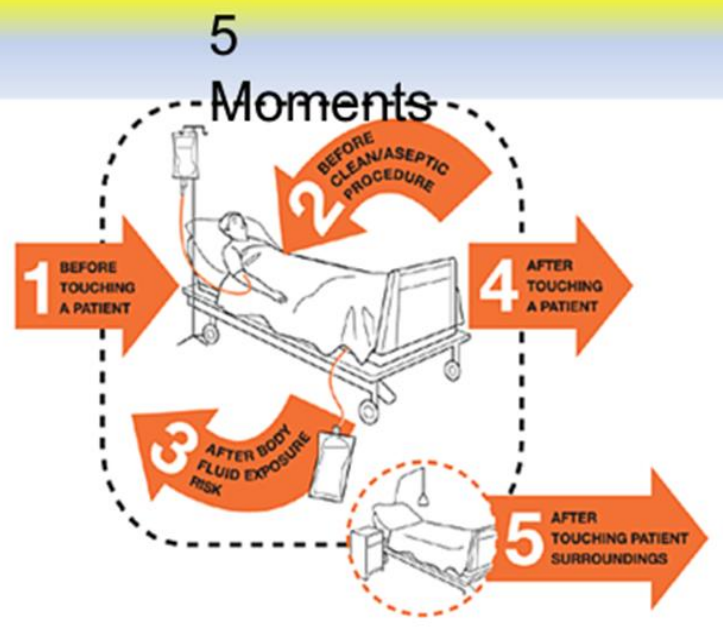

Gb. 4.3 Lima momen cuci tangan Sumber: WHO 2009

Praktik Mencuci Tangan

Teknik mencuci tangan biasa

Persiapan Alat :

- Sabun cair/ batang dalam tempatnya /cairan antiseptik lainya.

- Air mengalir secukupnya

- Hand towel tissue/ handuk sekali pakai

Prosedur Kerja

- Melepas perhiasan dan jam tangan di lengan bawah

- Menyingsingkan lengan baju sampai siku

- Membasahi kedua telapak tangan

- Mengambil sabun secukupnya

- Mengosok kedua telapak tangan

- Mengosok punggung tangan kanan dan kiri bergantian

- Mengosok sela-sela jari kanan dan kiri

- Mengosok buku-buku tangan kanan dan kiri 
- Putar ibu jari dalam telapak tangan yang berlawanan

- Gosok ujung jari di telapak tangan yang berlawanan, kanan dan kiri

- Basuh kedua tangan dengan air mengalir

- Keringkan dengan tissu atau handuk sekali pakai

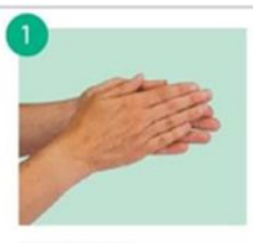

rub palm on palm

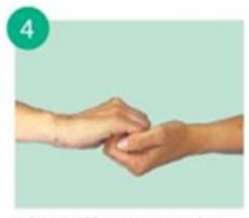
rub back of fingers on opposing
polms whth hands interlocked

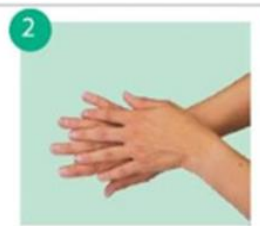

rub left palm over back of right hand and vice vers

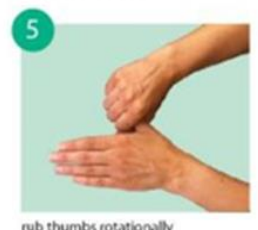

nob thumbs rotationally

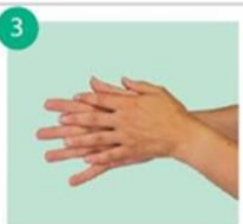

rub palm on palm with fingers interlaced

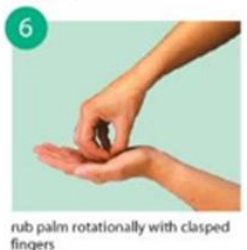

Gb.4.4 Enam langkah cuci tangan Sumber : Guidelines WHO 2009

\section{2) Alat Perlindungan Diri (APD)}

Alat pelindung diri adalah pakaian khusus atau peralatan yang di pakai petugas untuk memproteksi diri dari bahaya fisik, kimia, biologi/bahan infeksius.

APD terdiri dari sarung tangan, masker/Respirator Partikulat, pelindung mata (goggle), perisai/pelindung wajah, kap penutup kepala, gaun pelindung/apron, sandal/sepatu tertutup (Sepatu Boot).

\section{Tujuan Pemakaian APD}

Melindungi kulit dan membran mukosa dari resiko pajanan darah, cairan tubuh, sekret, ekskreta, kulit yang tidak utuh dan selaput lendir dari pasien ke petugas dan sebaliknya.

Indikasi penggunaan APD 
Jika melakukan tindakan yang memungkinkan tubuh atau membran mukosa terkena atau terpercik darah atau cairan tubuh atau kemungkinan pasien terkontaminasi dari petugas. Tindakan melepas APD

- Melepas APD segera dilakukan jika tindakan sudah selesai di lakukan.

- Tidak dibenarkan menggantung masker di leher, memakai sarung tangan sambil menulis dan menyentuh permukaan lingkungan.

\section{Menggunakan Sarung tangan}

Sarung tangan digunakan dalam melakukan prosedur tindakan, dengan tujuan mencegah terjadinya penularan kuman dan mengurangi risiko tertularnya penyakit.

Sarung tangan tidak menggantikan perlunya cuci tangan.

Jenis sarung tangan

a) Sarung tangan Bedah yaitu sarung tangan yang digunakan untuk tindakan invasive atau pembedahan

b) Sarung tangan pemeriksaan, yaitu sarung tangan untuk melindungi petugas pada saat melaksanakan tindakan pemeriksaan rutin

c) Sarung tangan rumah tangga yaitu sarung tangan yang dipakai pada saat menangani alat/bahan terkontaminasi atau permukaan yang terkontaminasi.

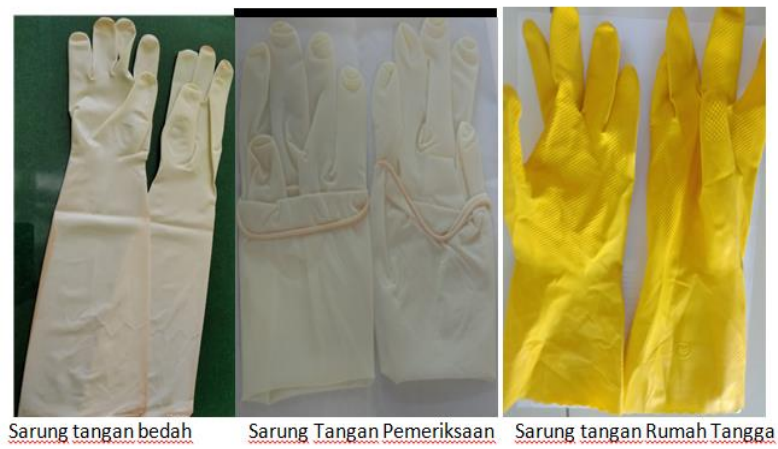




\section{Gb.4.5 Macam-macam Sarung tangan}

\section{Menggunakan masker}

Tindakan pengamanan yang menutup hidung dan mulut dengan menggunakan masker, bertujuan untuk mencegah atau mengurangi transmisi droplet mikroorganisme saat merawat pasien.

Macam-macam masker

a) Masker bedah dipakai pada tindakan bedah atau untuk mencegah penularan lewat droplet

b) Masker respiratorik digunakan untuk mencegah penularan lewat udara

c) Masker rumah tangga dipakai di bagian gizi atau dapur

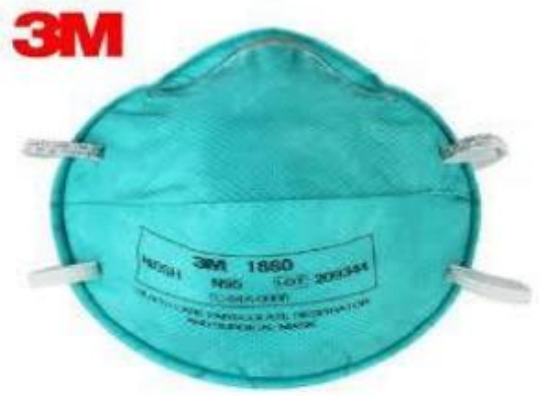

Gb.4.6 Masker respirator

Sumber: PMK no. 27 tahun 2017

\section{Menggunakan gaun pelindung}

Gaun pelindung berfungsi untuk melindungi baju petugas dari kemungkinan terpapar percikan cairan dan duh tubuh pasien atau melindungi pasien dari paparan pakaian petugas yang tidak steril.

Macam-macam gaun pelindung
a) Gaun pelindung tidak kedap air
b) Gaun pelindung kedap air
c) Gaun Steril
d) Gaun non steril 


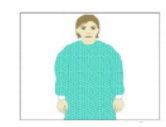

Gb. 4.7 Gaun Pelindung

Sumber : PMK No. 27 tahun 2017

\section{Menggunakan Google dan perisai wajah}

Bertujuan untuk melindungi mata dan wajah dari percikan cairan dan duh tubuh pasien.

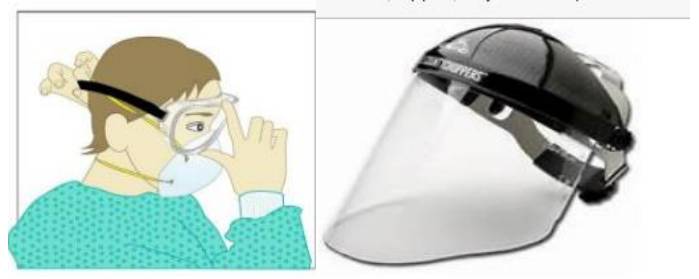

Gb. 4.8 Google dan persiai wajah Sumber : PMK No. 27 tahun 2017

\section{Menggunakan Sepatu Pelindung}

Bertujuan untuk melindungi kaki petugas dari tumpahanatau percikan darah/cairan tubuh serta mencegah kemungkinan tertusuk benda tajam atau kejatuhan alat kesehatan

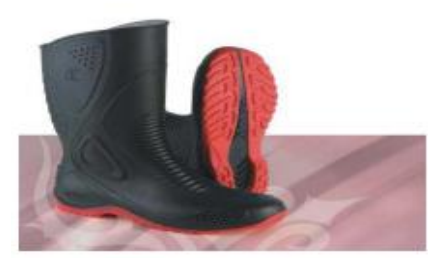

Gb.4.9 Sepatu pelindung

Sumber : PMK No. 27 tahun 2017

\section{Topi Pelindung}


Digunakan untuk mencegah jatuhnya mikroorganisme yang ada dirambut atau kulit kepal petugas terhadap alat-alat /daerah steril atau membrane mukosa pasien dan juga sebaliknya.

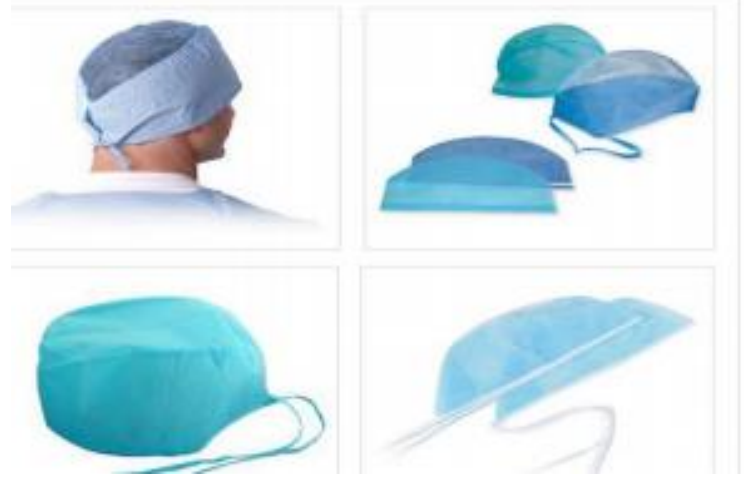

Gb. 4.10 Topi pelindung

Sumber: PMK no. 27 Tahun 2017

\section{3) Teknik Aseptik}

Asepsis atau teknik Aseptik : upaya kombinasi untuk mencegah masuknya mikroorganisme kedalam tubuh.

Antiseptik yaitu bahan kimia yang dipakai pada kulit / jaringan hidup lainnya untuk menghambat atau membunuh mikroorganisme (baik transien atau residen)

Tujuan : Memusnahkan semua kuman-kuman patogen, kecuali spora Larutan antiseptik yang dianjurkan :

- Larutan yang berbahan dasar alkohol (tingtur) seperti iodin (3\%) atau klorofol (7,5-10\%) misal : betadine

- Alkohol (60-90\%)

- Klorheksidin glukonat (2-4\%), misal : Hibitane, Hibiscrub, Hibiclen)

- Klorheksidin glukonat dan setrimid (misal savlon)

Disinfeksi yaitu proses pemusnahan sebagian mikroorganisme penyebab penyakit dari benda mati 
Disinfektan: bahan kimia yang menghancurkan/menginaktivasi mikroorganisme.

Bahan : fenol, klorin atau derivat klorin dan bahan amonia kwarternari (QUAT)

\section{4) Pemrosesan Alat}

Untuk memproses alat medik yang telah digunakan dalam prosedur invasif, agar tidak mengkontaminasi serta untuk mematikan virus baik Hepatitis B, maupun HIV atau sejenisnya.

Pemrosesan alat bekas pakai melalui tahapan dekontaminasi, cuci bilas dengan detergen dan air mengalir, kemudian dilakukan Desinfeksi tingkat tinggi (DTT) atau dilakukan sterilisasi. Untuk Lebih jelasnya bias dilihat pada skema di bawah ini :

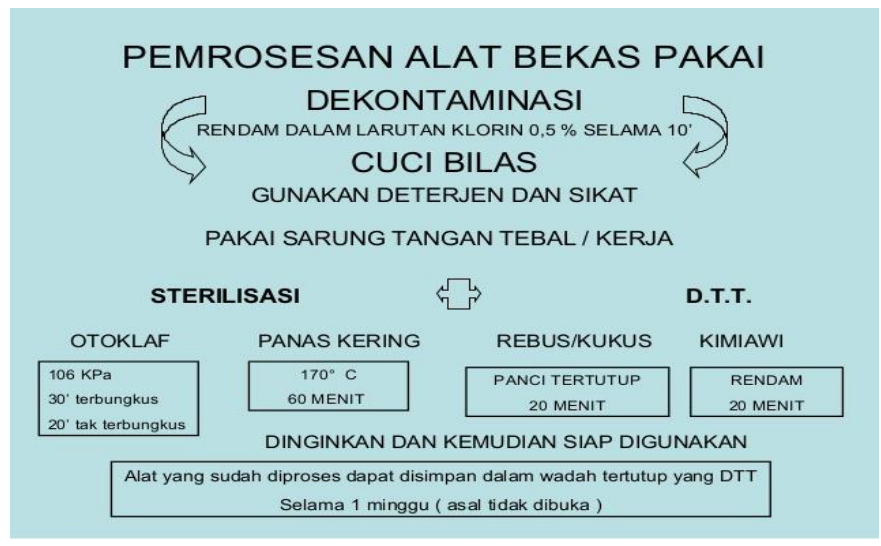

\section{Dekontaminasi}

Dekontaminasi adalah tindakan awal yang dilakukan agar alat, handschoon, perlengkapan yang terkontaminasi, supaya aman diproses oleh petugas kebersihan. Dekontaminasi dengan merendam alat bekas pakai dengan larutan klorin 0,5\%.

Dekontaminasi dilakukan bertujuan untuk:

- Mencegah infeksi dan mengurangi transmisi penyakit yang ada pada alat bekas pakai 
- Menghiangkan mikroorganisme yang ada pada alat bekas pakai yang digunakan dalamkeokteran dan perawatan

- Menghalangi perluasan infeksi dari peralatan atau permukaan lingkungan seperti tempat persalinan, operasi dan lain-lain..

- Menghilangkan kotoran yag terlihat maupun tidak

Rumus membuat larutan Klorin

$$
\text { Jumlah bagian air }=\frac{\text { \% larutan konsentrat }}{\text { \% larutan yang diinginkan }}-1
$$

Cara membuat larutan klorin 0,5\% dari sediaan 5,25\% adalah sebagai berikut :

Jumlah Bagian air $=\underline{5 \%}-1$

$$
0,5 \%
$$

Jadi hasilnya perbandingan air dan klorin = $9: 1$ artinya tambahkan 9 bagian air kedalam bagian larutan klorin pekat $5 \%$

Seperti contoh : apabila membuat larutan klorin 0,5\% sebanyak 1 liter, maka caranya adalah :

Air $=9 / 10 \times 1000 \mathrm{cc}=900 \mathrm{cc}$

Klorin $=1 / 10 \times 1000 \mathrm{cc}=100 \mathrm{cc}$

Jika tambahkan $900 \mathrm{cc}$ air dan klorin $100 \mathrm{cc}$

Rumus membuat larutan klorin 0,5\% dari serbuk kering

$$
\sum \text { bagian air }=\frac{\% \text { larutan yang diinginkan x }}{\% \text { larutan konsentrat }} 1000
$$

Misalnya: 
Cara menyiapkan larutan dekontaminasi 0,5\% yang berasal dari bubuk klorin yang tersedia contohnya Kalsium, kaporit yang kandungan klorinya 35\%

$$
\text { Gram } / \text { liter }=\frac{0,5 \% \times 1000=14,3 \text { gram } / \text { liter }}{35 \%}
$$

Jadi hasilnya 1 liter air bersih diberi klorin bubuk 35\% sebanyak 14,3 gram.

\section{Praktik membuat larutan untuk dekontaminasi ( klorin 0,5\%)}

Persiapan Alat

- Air mentah bersih

- Desinfektan (Klorin 5,25\%)

- Handscoon kerja/Industri

- Gelas ukur

- 2 baskom/ ember

- Peralatan yg akan didekontaminasi

ProsedurKerja

- Menghitung kebutuhan air dan klorin untuk dekontaminasi alat dalam larutan klorin 0,5\%

- Memasukkan bagian air mentah bersih ke dalam ember.

- Memasukkan bagaian klorin ke dalam ember yang telah berisi air mentah bersih tersebut.

- Lakukan perendaman selama 10 menit

Pencucian yang benar menggunakan sabun dan air Jika dengan air saja $50 \%$ sedangkan dengan sabun sampai $80 \%$ efektifitas menghilangkan mikroorganisme dan pembilasan menggunakan air menggunakan air mengalir.

\section{Praktik Dekontaminasi dan cuci bilas}

- Memakai sarung tangan kerja/ Rumah Tangga

- Menyiapkan klorin 0,5\% dalam ember plastik

- Merendam alat-alat bekas pakai dalam cairan klorin 0,5 $\%$ selama 10 menit. 
- Mencuci alat tersebut dengan detergen, sikat semua geligi, sambungan dan permukaan alat.

- Membilas alat-alat tersebut dengan air mengalir hingga detergen hilang/bersih

- Keringkan instrument

\section{Desinfeksi Tingkat Tinggi (DTT)}

Yaitu merupakan tindakan untuk menghilangkan semua mikroorganisme pada benda mati kecuali bakteri beberapa endospora. Ada 3 macam cara DTT yaitu DTT kimiawi, merebus dan mengukus.

\section{Desinfeksi Tingkat Tinggi (DTT) kimia}

Tujuan

- Menghilangkan semua mikroorganisme kecuali endospora

Persiapan Alat

- Cairan desinfektan (klorin 0,1\%).

- Alat-alat yang sudah di proses cuci bilas

- Baskom/ Ember

Prosedur Kerja

- Ganti air setiap kali mendesinfeksi peralatan

- Rendam peralatan di dalam kLorin $1 \%$ sehingga semuanya terendam selama 20 menit.

- Bilas dengan air steril/ matang sebelum digunakan atau disimpan.

- Biarkan peralatan kering dengan cara diangin-anginkan sebelum digunakan/ disimpan

- Meletakkan alat dalam tempat yang sudah di DTT dan peralatan bisa segera dipakai.

- Cuci tangan

- Memberi label yang bertuliskan tanggal dilaksanakan DTT masa efektifnya 1 minggu.

\section{Praktik Dekontaminasi Tingkat Tinggi (DTT) Rebus}


Tujuan

Menghilangkan semua mikroorganisme kecuali endospora

Persiapan Alat

- Panci perebus (kalakat 3 susun, dandang)

- Kompor LPG

- Alat-alat yang sudah di proses cuci bilas

Prosedur Kerja

- Ganti air setiap kali mendesinfeksi peralatan

- Rendam peralatan di dalam air sehingga semuanya terendam air

- Mulai panaskan air, hitung waktu saat air mendidih, Jangan tambahkan benda apapun ke dalam air mendidih setelah penghitungan waktu dimulai

- Rebus selama 20 menit

- Setelah 20 menit, mengeluarkan instrumen segera dengan menggunakan korentang, tidak menunggu sampai air menjadi dingin.

- Biarkan peralatan kering dengan cara diangin-anginkan sebelum digunakan.

- Meletakkan alat dalam tempat yang sudah di DTT dan peralatan bisa segera dipakai.

- Cuci tangan

- Memberi label yang bertuliskan tanggal dilaksanakan DTT masa efektifnya 1 minggu.

\section{Desinfeksi Tingkat T inggi (DTT) dengan cara Kukus}

Tujuan

- Menghilangkan semua mikroorganisme kecuali endospora

Persipan alat

- Panci perebus dengan nampan 3 susun,

- Alat-alat yang sudah di proses cuci bilas.

Prosedur Kerja 
- Ganti air setiap kali mendesinfeksi peralatan

- Alasi pengukus dengan kain dan meletakkan sarung tangan 5-15 sarung tangan/ alat yang mau dikukus. Lakukan kembali pada panci yang kedua.

- Panci perebus disusun tiga tingkat yang ada airnya ditaruh paling bawah.

- Letakkan penutup di atas nampan pengukus paling atas dan panaskan air hingga mendidih..

- Lama DTT kukus 20 menit, dihitung setelah air mendidih. Selama psoses mengukus berlangsung tidak boleh menambahkan alat lagi

- Ambil panci yang berisi sarung tangan paling atas goyangsecara pelan supaya airnya menetes keluar..

- Agar sarung tangan tidak terkontaminasi dan menjadi dingin dengan meletakkan penutup diatasnya. Serta mendiamkan selama 4-6 jam.

- Jika dibutuhkan segera diamkan alat dan handscoon selama 5-10 menit supaya dingin..

- Cuci tangan

- Memberi label yang bertuliskan tanggal dilaksanakan DTT masa efektifnya 1 minggu.

\section{Sterilisasi}

Tujuan

- Menghilangkan semua mikroorganisme termasuk endospora.

Praktik sterilisasi

Persiapan alat

- Sterilisator

- Alat-alat yang akan di steril

Prosedur Kerja

- Mencuci tangan dengan sabun dan air mengalir, mengeringkan dengan handuk bersih. 
- Memasukkan alat-alat ke dalam sterilisator

- Mengatur suhu:

- Sterilisasai uap $121{ }^{\circ} \mathrm{C}$

- Sterilisasi panas kering (oven) $170{ }^{\circ} \mathrm{C}$

- Menyebutkan waktu sterilisasi:

- Sterilisasai uap, untuk alat yang terbuka disterilisasi selama 20 menit, sedangkan alat yang tertutup atau dibungkus disterilisasi selama 30 menit

- Sterilisasi panas kering (oven) $170{ }^{\circ} \mathrm{C}$ waktu yang diperlikan 60 menit.

- Sterilisasi kimia : direndam dalam glutaraldehid (Cidex). selama 8-10 jam, bilas dengan air steril sebelum digunakan atau disimpan.

- Diamkan semua alat sampai kering sebelum diangkat

- Cuci tangan

- Memberi label yang bertuliskan tanggal dilaksanakan DTT masa efektifnya 1 minggu.

\section{5) Pengelolaan sampah}

Sampah merupakan suatu bahan yang berasal dari kegiatan manusia dan sudah tidak dipakai atau dibuang oleh manusia.

\section{Tujuan pengelolaan sampah}

- Melindungi petugas pembuangan sampah dari perlukaan

- Melindungi penyebaran infeksi terhadap petugas kesehatan

- Mencegah penularan infeksi pada masyarakat

- Membuang bahan-bahan berbahaya dengan aman

Berdasarkan sifatnya sampah digolongkan menjadi 2 macam yaitu :

- Sampah basah sampah berasal dari darah, duh tubuh yang lain, jaringan placenta dan lain-lain

- Sampah kering sampah yang berupa kasa, kapas, jarum dan lain-lain 
Selain itu berdasarkan pengelolaannya sampah juga di kategorikan dalam sampah terkontaminasi atau tidak terkontaminasi.

\section{Pembuangan sampah terkontaminasi}

- Menuangkan cairan atau sampah basah ke sistem pembuangan kotoran tertutup

- Insenerasi (pembakaran) untuk menghancurkan bahanbahan sekaligus mikroorganismenya (ini merupakan metode terbaik untuk pembuangan sampah terkontaminasi. Pembakaran juga akan mengurangi volume sampah dan memastikan bahwa bahan-bahan tersebut tidak akan dijarah dan dipakai lagi.

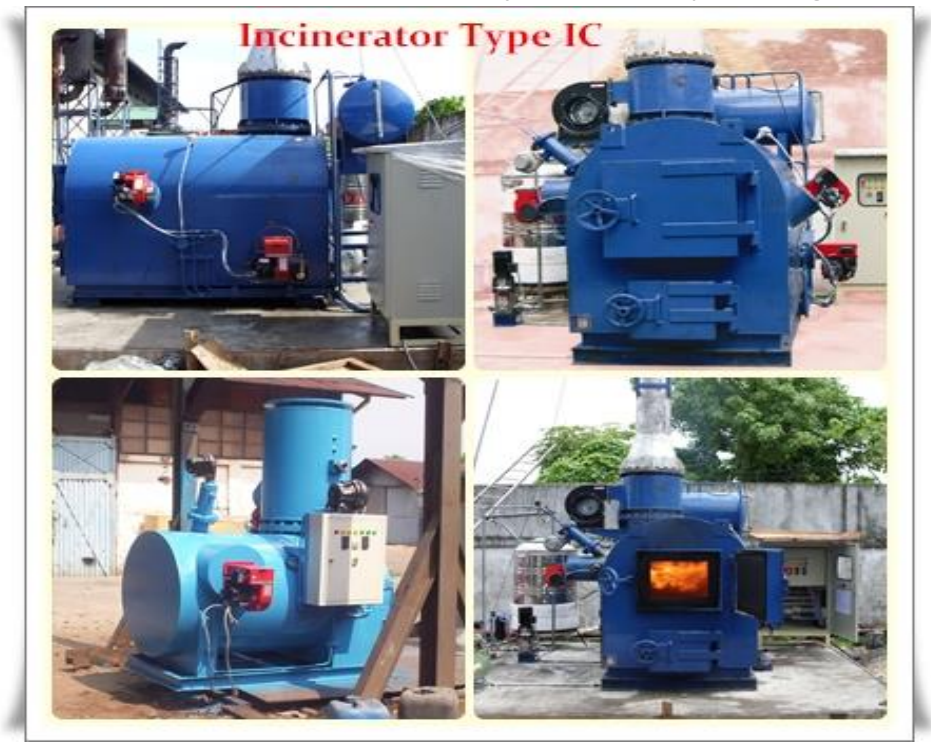

Gb. 4.11 Insenerator

Sumber:https://rekayasahijau.com/id/produk-danjasa/incinerator/

- Menguburkan sampah terkontaminasi untuk mencegah ditangani lebih lanjut.

\section{Membuang sampah benda tajam}


Benda-benda tajam sekali pakai (jarum suntik, jarum jahit, silet, pisau, scalpel) memerlukan penanganan khusus karena benda tersebut dapat meluakai petugas kesehatan dan masyarakat sekitarnya jika sampah dibuang ditempat pembuangan sampah umum.

Enkapsulasi dianjurkan sebagai cara termudah membuang bendabenda tajam. Benda tajam dikumpulkan dalam wadah tahan tusukan dan antibocor. Sesudah $3 / 4$ penuh, bahan seperti semen, pasir, atau bubuk plastik dimasukkan dalam wadah sampai penuh. Sesudah bahan-bahan menjadi padat dan kering, wadah ditutup disebarkan pada tanah yang rendah, ditimbun dan dapat dikubur. Bahan-bahan sisa kimia dapat dimasukkan dengan benda-benda tajam.

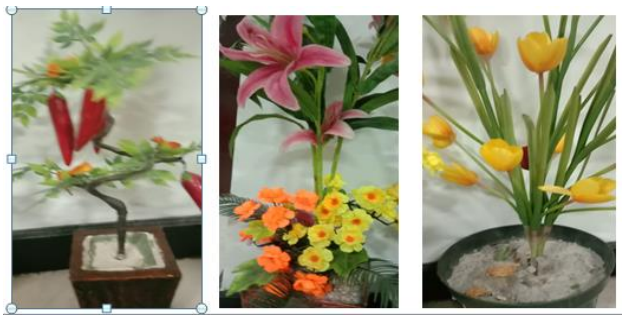

Gb. 4.12 Enkapsulasi

\section{Kesimpulan}

1. Keselamatan pasien merupakan upaya untuk menghindari, mencegah dan memperbaiki hasil tindakan yang buruk yang buruk atau injuri yang berasal dari proses perawatan kesehatan.

2. Beberapa insiden keselamatan pasien yaitu Insiden Keselamatan Pasien (IKP), Kejadian yang Tidak Diharapkan (KTD), Kejadian Nyaris Cedera (KNC), Kejadian Tidak cedera (KTD), Kondisi Potensial Cedera (KPC) dan Kejadian Sentinel

3. Solusi keselamatan pasien di rumah sakit meliputi perhatian nama obat sama dan ucapan mirip, indentifikasi pasien, informasi serah terima pasien yang tepat, memastikan tindakan yang benar pada 
sisi tubuh yang benar, mengatur konsentrasi cairan elektrolit yang pekat, ketepatan pemberian obat, mencegah kesalahan pemasangan kateter dan meningkatkan kebersihan tangan.

4. 11 kewaspadaan standar, kebersihan tangan, alat Pelindung Diri (APD), dekontaminasi peralatan perawatan pasien,kesehatan lingkungan, pengelolaan limbah, penatalaksanaan linen, perlindungan kesehatan petugas, penempatan pasien, hygiene respirasi/etika batuk dan bersin, praktik menyuntik yang aman dan praktik lumbal pungsi yang aman.

5. Transmisi kuman melalui reservoir, jalan masuk, host, jalan keluar dan saluran penyebaran.

6. Cara penularan infeksi melalui kontak langsung/tidak langsung, percikan, udara, makanan dan minuman, serta melalui vector

7. Tindakan pencegahan infeksi melalui cuci tangan, pemakaian Alat Perlindungan Diri (APD) Teknik aseptik, pemrosesan alat dan pengelolaan sampah.

\section{Latihan Soal}

1. Tindakan untuk menghilangkan semua mikroorganisme (bakteri, jamur, parasit, dan virus) termasuk bakteri endospore adalah

a. Flambir

b. Dekontaminasi

c. Sterilisasi

d. Desinfeksi

e. Desinfeksi tingkat tinggi

2. Berikut ini pemrosesan alat bekas pakai yang tepat adalah

a. Dekontaminasi dengan larutan klorin 0,5\% selama 10 menit, cuci bilas, DTT/Sterilisasi

b. Dekontaminasi dengan larutan klorin 0,5\% selama 15 menit, cuci bilas, DTT/Sterilisasi

c. Dekontaminasi dengan larutan klorin 0,5\% selama 20 menit, cuci bilas, DTT/Sterilisasi 
d. Cuci bilas, Dekontaminasi dengan larutan klorin 0,5\% selama 10 menit, DTT/Sterilisasi

e. Dekontaminasi dengan larutan klorin 0,5\% selama 10 menit DTT, cuci bilas dan sterilisasi

3. Pembuatan larutan klorin $0,5 \%$ dengan kosentrat $5 \%$ sebanyak 5000cc, berapakah jumlah klorin dan air yang dibutuhkan
a. Air : 1500 , klorin : 3500
b. Air : 4500 , klorin : 500
c. Air : 3500 , klorin : 1500
d. Air : 500 , klorin : 4500
e. Air : 2000, klorin : 3000

4. Penanganan sampah benda tajam dengan mengumpulkan dalam wadah tahan tusukan dan anti bocor, sesudah $3 / 4$ penuh diberi semen dan pasir disebut
a. Insenerasi
b. Enkapsulasi
c. Inseminasi
d. Reduce
e. Distilasi

5. Tanda -tanda infeksi secara klinis dapat dilihat pada respon klinis lokal dan sistematik, tanda klinis lokal yaitu
a. Merah, panas, nyeri, tumor, fungsiolesa
b. pucat, panas, nyeri, tumor, fungsiolesa
c. Merah, syok, nyeri, tumor, fungsiolesa
d. Merah, panas, nyeri, Fever, fungsiolesa
e. Bengkak, panas, nyeri, tumor, fungsiolesa

6. Setiap kejadian / situasi yang dapat mengakibatkan atau berpotensi mengakibatkan harm (penyakit, cedera, cacat, kematian dan lain- lain) yang tidak seharusnya terjadi. Disebut
a. Insiden Keselamatan Pasien
b. Kejadian Tidak Diharapkan 

c. Kejadian Nyaris Cedera
d. Kejadian Tidak Cedera
e. Kejadian Potensial Cedera

7. Yang tidak termasuk dalam 7 standar keselamatan pasien

a. Hak pasien

b. Mendidik pasien dan keluarga

c. Komunikasi

d. Peran staf dalam meningkatkan keselamatan

e. Keselamatan pasien dan kesinambungan pelayanan

8. Pada pasien yang mengalami alergi obat maka untuk identifikasi dalam keselamatan pasien bidan memberikan gelang warna.....
a. Merah mudah
b. Biru
c. Kuning
d. Hijau
e. Merah

9. Komunikasi Efektif dengan SBAR yang artinya

a. Situation,Behavior, assesment dan Recommendation

b. Simptom, Behavior, assesment dan Recommendation

c. Situation, Behavior, analisys dan Recommendation

d. Situation, Background, analisys dan Recommendation

e. Situation,Background, Assesment dan Recommendation

10. Jika ada pasien baru sebelum lapor ke dokter sebaiknya Sikap seorang bidan adalah
a. Menentukan diagnosa
b. Menjelaskan masalah Pasien
c. Mengkaji kondisi pasien
d. Menjelaskan hasil pemeriksaan
e. Menanyakan apa tindakan yang dilakukan

\section{Daftar Pustaka}


Hidayat, A. Aziz Alimul dan Uliyah, M. 2011. Buku Saku Prosedur Ketrampilan Dasar Praktik Klinik. Surabaya: Health Books Publishing.

JNPKR. JHPIEGO. 2004. Panduan Pencegahan Infeksi. Jakarta. YBP-SP

Kasiati., Rosmalawati, Ni Wayan Dwi. 2016. Kebutuhan Dasar Manusia. Jakarta : Pusdik SDM

Nursing Drug Handbook. (2012). Lippincott Williams \& Wilkins:

Philadelphia, Pennsylvania.

Peraturan Menteri Kesehatan No. 27 Tahun 2017 tentang pedoman pengendalian Infeksi di Fasilitas Pelayanan Kesehatan

https://spo-keperawatan.blogspot.com/2016/06/spo-pengelolaanobat-lasa.html

https://rekayasahijau.com/id/produk-dan-jasa/incinerator/

http://identitaspasien.arata.co.id/produk/gelang-pasien/ 


\section{BAB V}

\section{KEBUTUHAN DASAR MANUSIA}

\section{Tujuan pembelajaran:}

Mahasiswa mampu menjelaskan dan menerapkan pemenuhan kebutuhan dasar manusia (kebutuhan cairan dan elektrolit, oksigen, nutrisi, istirahat tidur, mekanik tubuh, posisi, ambulasi dan mobilitas, serta eliminasi)

\section{A. Kebutuhan Cairan dan Elektrolit}

Kebutuhan cairan merupakan kebutuhan dasar manusia secara fisiologis ini memiliki proporsi besar dalam bagian tubuh dengan hampir $90 \%$ dari total berat badan, sisanya merupakan bagian padat dari tubuh.

Eleltrolit terdapat pada seluruh cairan tubuh, cairan tubuh mengandung oksigen, nutrient dan sisa metabolisme yang semuanya disebut ion. Beberapa jenis garam dalam air yang akan dipecah dalam bentuk ion elektolit.

1. Elektrolit yang berperan dalam mekanisme pertukaran Cairan Intra Selulker ( CIS) \& Cairan Ekstra Seluler (CES)

Tabel 5.1 Tabel elektrolit

\begin{tabular}{|ll|ll|}
\hline \multicolumn{2}{|c|}{ Anion } & \multicolumn{2}{c|}{ Kation } \\
\hline Klorida & $\mathrm{Cl}$ & Natrium & $\mathrm{Na}^{+}$ \\
\hline Sulfat & $\mathrm{SO}_{4}{ }^{2}$ & Kalium & $\mathrm{K}^{+}$ \\
\hline Fosfat & $\mathrm{PO}_{4}{ }^{3}$ & Kalsium & $\mathrm{Ca}^{2+}$ \\
\hline Bikarbonat & $\mathrm{HCO}_{3}$ & Magnesium & $\mathrm{Mg}^{2+}$ \\
\hline
\end{tabular}

2. Cara perpindahan cairan tubuh.

a. Difusi yaitu pergerakan cairan tubuh dari tempat yang berkonsentrasi tinggi ke tempat yang berkonsentrasi rendah melalui membrane semipermiabel. 
Kecepatan difusi dipengaruhi oleh 3 hal : ukuran molekul, konsentrasi larutan, temperatur laruran

b. Osmosis yaitu Perpindahan cairan melintasi membran semipermiabel dari area berkonsentrasi rendah menuju area yang berkonsentrasi tinggi.

c. Transport aktif yaitu gerak zat yang akan berdifusi atau berosmosis yang memerlukan aktifitas metabolik dan pengeluaran energi untuk menggerakkan berbagai materi guna menembus membrane sel.

3. Pengaturan keseimbangan cairan terjadi melalui mekanisme rasa haus yang dikontrol oleh sistem endokrin (hormonal), yakni antdiuritik hormone $A D H$, sistem aldosterone, prostaglandin, dan glukokortikoid.

$\mathrm{ADH}$ memiliki peran meningkatkan reabsorbsi air sehingga dapat mengendalikan keseimbangan air dalam tubuh.

Aldosteron proses pengeluaran hormon ini diatur oleh adanya perubahan konsentrasi kalium, natrium dan angiotensin renin.

Prostaglandin mempunyai peran mengatur sirkulasi ginjal.

Glukokortikoid mengatur peningkatan reabsopsi natrium dan air yang menyebabkan volume darah meningkat sehingga terjadi retensi natrium.

Mekanisme rasa haus diatur dalam rangka memenuhi kebutuhan cairan dengan merangsang pelepasan renin. Pelepasa renin tersebut dapat menimbulkan produksi angiotensin II yang merangsang hypothalamus sehingga menimbulkan rasa haus.

4. Pengeluaran cairan melalui Ginjal, kulit, paru, dan gastrointestinal

a. Ginjal

Fungsi Ginjal : pengatur air, pengatur konsentrasi garam dalam darah, pengatur keseimbangan asam-basa darah, dan ekskresi bahan buangan / kelebihan garam. 
Jumlah urine yg diproduksi ginjal dapat dipengaruhi oleh $\mathrm{ADH}$ dan aldosteron dengan rata-rata $1 \mathrm{ml} / \mathrm{kg} \mathrm{BB} / \mathrm{jam}$

Pada individu dewasa, ginjal mengekskresikan sekitar $1500 \mathrm{ml} /$ hari

b. Kulit

Kulit merupakan bagian penting dalam pengaturan cairan yg terkait dengan proses pengaturan panas.

Proses pelepasan panas dapat dilakukan dgn cara penguapan.

Jumlah keringat yg dikeluarkan tergantung pada banyaknya darah yang mengalir melalui pembuluh darah dalam kulit. Dalam 24 jam pengeluaran cairan lewat kulit sekitar $15-20 \mathrm{ml}$.

c. Paru-paru

Organ paru berperan dalam pengeluaran cairan dengan menghasilkan insensible water loss (IWL) $\pm 400 \mathrm{ml} /$ hari.

Proses pengeluaran cairan terkait dgn respons akibat perubahan terhadap upaya kemampuan bernafas.

d. Gatrointestinal

Organ saluran pencernaan yg berperan dalam mengeluarkan cairan melalui proses penyerapan dan pengeluaran air. Dalam kondisi normal cairan yg hilang dalam sistem ini sekitar $100-200 \mathrm{ml} /$ hari

\section{Intake dan output cairan}

a. Intake Cairan

Selama aktivitas dan temperatur yg sedang, seorang dewasa minum kira2 $1500 \mathrm{ml} /$ hari, sedangkan kebutuhan cairan tubuh kira2 2500 $\mathrm{ml} /$ hari sehingga kekurangan sekitar $1000 \mathrm{ml} /$ hari diperoleh dari makanan dan oksidasi selama proses metabolisme.

Tabel 5.2 Kebutuhan Cairan air berdasarkan umur dan Berat Badan (BB)

\begin{tabular}{|c|c|c|}
\hline \multirow{2}{*}{ Umur } & \multicolumn{2}{|c|}{ Kebutuhan air } \\
\cline { 2 - 3 } & Jumlah air dalam 24 Jam & $\mathrm{ml} / \mathrm{KgBB}$ \\
\hline 3 Hari & $250-300$ & $80-100$ \\
\hline 1 Tahun & $1150-1300$ & $120-135$ \\
\hline
\end{tabular}




\begin{tabular}{|c|c|c|}
\hline 2 Tahun & $1350-1500$ & $115-125$ \\
\hline 4 Tahun & $1600-1800$ & $100-110$ \\
\hline 10 Tahun & $2000-2500$ & $70-85$ \\
\hline 14 Tahun & $2200-2700$ & $50-60$ \\
\hline 18 Tahun & $2200-2700$ & $40-50$ \\
\hline dewasa & $2400-2600$ & $20-30$ \\
\hline
\end{tabular}

b. Output cairan

Output cairan melalui beberapa cara antara lain:

1) Urine

Pada orang dewasa dalam kondisi normal pengeluaran cairan lewat urine sebanyak 30-50 cc/jam atau 1400-1500 cc dalam 24 jam.

2) IWL (Insesible Water Loss)

Kehilangan cairan tubuh pada proses ini sekitar 300-400 ml/hari melalui kulit dan paru-paru.

3) Keringat

4) Feses

Pengeluaran air melalui feses berkisar $100-200 \mathrm{ml} / \mathrm{hari}$.

\section{e. Ketidakseimbangan cairan}

Ketidakseimbangan cairan bisa melalui defisit volume Cairan dan volume cairan berlebih.

a. Defisit Cairan

Suatu keadaan tidak seimbang dimana terjadi kekurangan cairan dan elektolit pada ruang ekstraseluler atau disebut juga hipovolemia. Secara umum, kondisi defisit volume cairan (dehidrasi) terbagi menjadi 3:

1) Dehidrasi isotonik : cairan = elektrolit

2) Dehidrasi hipertonik : cairan > elektrolit

3) Dehidrasi Hipotonik : cairan < elektrolit

Menurut Derajat Keparahannya Dehidrasi Digolongkan Menjadi :

1) Dehidrasi Ringan: Kehilangan cairan mencapai $5 \%$ dari berat tubuh atau sekitar 1,5-2 liter 
2) Dehidrasi Sedang : Kehilangan cairan mencapai $5-10 \%$ dari berat tubuh atau sekitar 2-4 liter. Gejala yang timbul salah satunya adalah mata cekung

3) Dehidrasi Berat : Kehilangan cairan mencapai 4-6 liter. Pada dehidrasi berat bisa terjadi hipotensi pada pasien.

b. Kelebihan cairan

Kondisi ketidak seimbangan cairan tubuh dimana terjadi kelebihan cairan dan natrium pada ruang ekstrasel atau disebut hypervolemia. Penyebab umum dari kelebihan cairan ini karena adanya gannguan pada fungsi ginjal.

Gejala kelebihan cairan ekstrasel :

1) Edema perifer

2) Asites

3) Kelopak mata bengkak

4) Bunyi nafas ronkhi basah di seluruh lapang paru

5) Penambahan Berat Badan yang tidak lazim

\section{f. Macam-macam Cairan}

a. Larutan Nutrien

Larutan ini berisi beberapa jenis karbohidrat dan air Larutan nutrien yg umum digunakan adalah $5 \%$ dekstrosa dalam air, 3,3 5 glukosa dalam 0,3\% NaCL, dan $5 \%$ glukosa dalam 0,45\% $\mathrm{NaCL}$.

b. Larutan Elektrolit

Jenis larutan elektrolit yg paling banyak digunakan adalah normal salin (isotonik) yaitu $\mathrm{NaCl}$ 0,9\%, Laktat Ringer ( $\mathrm{NA}+, \mathrm{K}+, \mathrm{Cl}-, \mathrm{Ca}+$ )

c. Cairan asam basa

Jenis yg termasuk cairan asam basa adalah natrium laktat dan natrium bikarbonat.

d. Volume Ekspander

Volume ekspander yg umum digunakan antara lain dekstran, plasma, dan albumin serum Berfungsi meningkatkan volume pembuluh darah atau plasma. 
g. Tindakan untuk mengatasi masalah gangguan kebutuhan cairan dan elektrolit

- Pemberian cairan infus

- Transfusi darah

Menghitung Tetesan Infus

Cara menghitung tetesan infus adalah sebagai berikut :

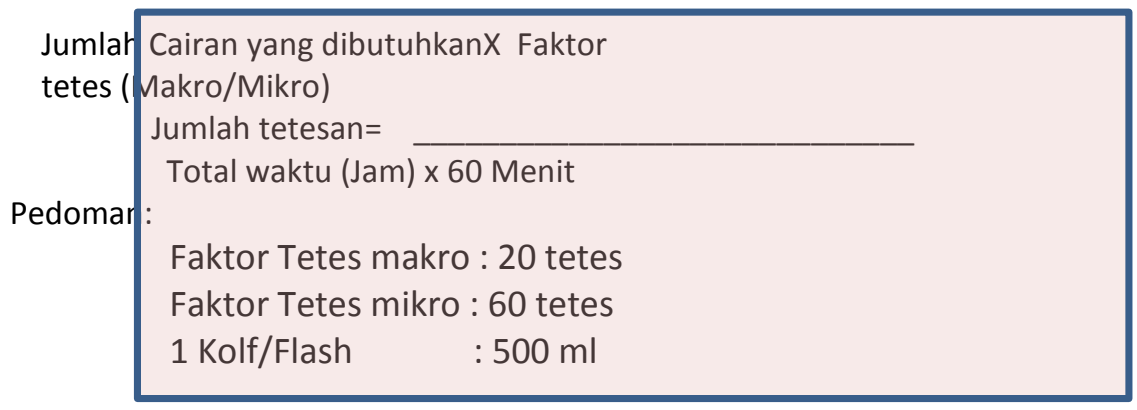

Selain itu ada cara lain untuk menghitung tetesan infus

1. Untuk Dewasa :

Tetesan $/$ menit $=$ Jumlah cairan yang masuk Lamanya infus (jam) $\times 3$

2. Untuk anak-anak

Tetesan $/$ menit $=\underline{\text { Jumlah cairan yang masuk }}$

Lamanya infus (jam)

Contoh :

Seorang pasien dewasa diperlukan rehidrasi dgn $500 \mathrm{ml} 1 \mathrm{klolf}$ dalam 5 jam, maka tetesan permenit adalah...

Jawab :

Diketahui : Jumlah Cairan $500 \mathrm{ml} / 1$ kolf

waktu 5 Jam

Ditanya : jumlah tetesan? 
Jawab : Tetesan/ menit = Jumlah cairan yg masuk

$$
\begin{aligned}
& \text { Lamanya infus (jam) } \times 3 \\
& \frac{500}{5} \times 3 \\
= & 33,3 / 33 \text { tetes } / \text { menit }
\end{aligned}
$$

Jadi tetesan infus yang diberikan adalah 33 tetes/menit.

h. Praktik Pemasangan infus

Persiapan Alat

- Kassa dalam kom.

- Kapas alkohol pada tempatnya.

- Alkohol $70 \%$ pada tempatnya.

- Infus set sesuai kebutuhan.

- Abbocat (untuk dewasa : 20 - 22 G, untuk anak : 24 - 26 G)

- Cairan infus yang diperlukan (RL, NS, D5\%, dsb)

- Duk + pengalas bersih.

- Sarung tangan disosable dalam kom.

- Torniquet.

- Standart infuse

- Bengkok

- Plester.

- Gunting plester

- Larutan klorin 0,5 \% dalam baskom

- Handuk Cuci Tangan

Persiapan Pasien

- Penjelasan prosedur kepada pasien mengenai tindakan yang akan dilakukan

Prosedur Kerja

- Dekatkan peralatan

- Pasang sampiran / tutup tirai / pintu ruangan

- Atur posisi pasien senyaman mungkin 
- Pasang pengalas dan perlak di bawah daerah yang akan di pasang infus

- Mencuci tangan

- Memakai sarung tangan disposable

- Buka kemasan steril infus

- Gantungkan cairan infus pada standar infus

- Atur klem rol sekitar 2-4 cm dibawah tabung tetesan (bilik drip) dan tutup klem yang ada pada saluran infus.

- Tusukkan pipa selang infus ke dalam botol cairan kemudian isi tabung tetesan setengah dengan cara memencet tabung tetesan infus

- Buka klem dan alirkan cairan keluar melalui selang, dan pastikan tidak ada udara pada selang infus lalu tutup kembali klemnya

- Cari dan pilih vena yang akan dipasang infus

- Letakkan torniquet $10-12 \mathrm{~cm}$ diatas tempat yang akan ditusuk (bila pemasangan infus dilakukan di daerah ekstremitas)

- Antisepsis daerah pemasangan secara sirkuler / melingkar

- Tusukkan jarum abocath ke vena dengan lubang jarum menghadap ke atas, lakukan aspirasi dengan menarik jarum ke bekalang (bila berhasil darah akan keluar dan dapat dilihat pada pipa abocath)

- Dorong pelan - pelan abocath masuk ke dalam vena, kemudian tekan ujung plastik abocath dan tarik pelan pelan jarum abocath keluar sehingga hanya tersisa plastik di dalam pembuluh vena.

- Sambungkan segera abocath dengan selang infus.

- Lepaskan torniquet dan longgarkan klem untuk melihat kelancaran tetesan.

- Bila tetesan sudah lancar, pangkal jarum di rekatkan pada kulit dengan plester 
- Atur tetesan sesuai dengan kebutuhan.

- Tutup tempat jarum atau tempat tusukan dengan kasa steril, fiksasi dengan plester secukupnya.

- Bereskan alat - alat dan rapikan pasien

- Lepaskan sarung tangan

- Cuci tangan

- Dokumentasikan

Pelepasan / Aff Infus

- Memberitahu pasien tindakan yang akan dilakukan

- Mendekatkan alat

- Cuci tangan

- Memasang perlak dan pengalas

- Memakai sarung tangan disposable

- Membasahi plester yang melekat dengan kulit dengan alkohol $70 \%$

- Melepas plester dan kasa dari kulit

- Menekan tempat tusukan dengan kapas alkohol kemudian mencabut infus pelan - pelan

- Menekan kapas alkohol dengan plester

- Membereskan alat dan merapikan pasien

- Melepas sarung tangan dan mencuci tangan

- Mendokumentasikan tindakan yang akan di lakukan

\section{B. Kebutuhan oksigen}

1. Kebutuhan oksigen digunakan manusia untuk kekangsungan metabolisme sel tubuh bagi individu dan untuk mempertahankan hidupnya. Sistem tubuh yang berperan dalam kebutuhan oksigenasi adalah saluran pernafasan atas (hidung, faring, laring dan epiglottis) dan saluran pernafasan bagian bawah (trachea, brokhus dn paru-paru) 


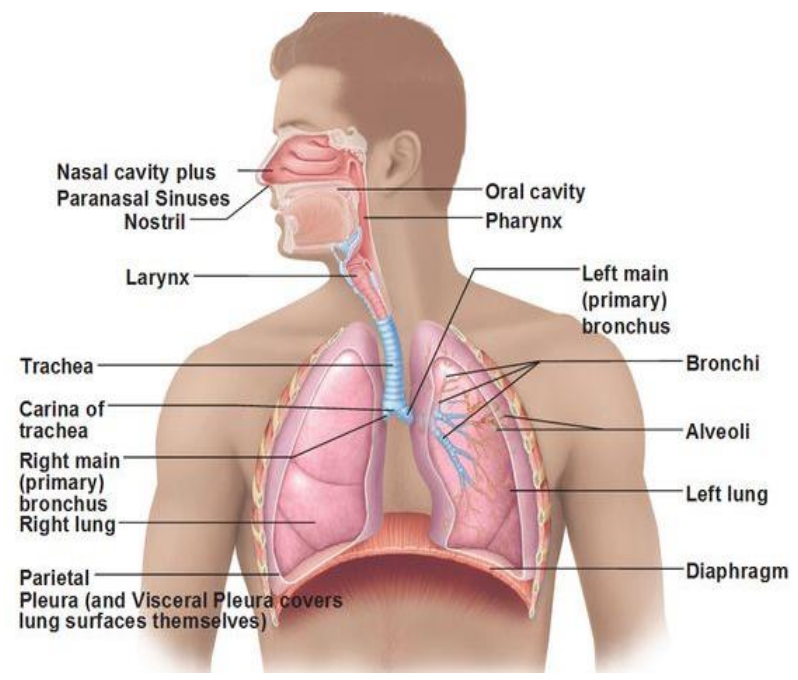

Gb. 5.1 Sistem Pernafasan

Sumber : $\underline{\text { https://owlcation.com }}$

\section{Proses oksigenasi}

Proses pemenuhan kebutuhan oksigenasi didalam tubuh terdiri atas tiga tahapan yaitu ventilasi, difusi dan transportasi.

a. Ventilasi adalah proses keluar masuknya oksigen dari atmosfer kedalam alveoli atau dari alveoli ke atmosfer. Proses ini dipengaruhi oleh konsentrasi oksigen diatmosfer ( tinggi suatu tempat maka tekanan udaranya semakin rendah) Kondisi jalan nafas yang baik dan kemampuan thorax dan alveoli pada paru-paru dalam melaksanakan ekspansi atau kembang kempis.

b. Difusi

Difusi gas merupakan pertukaran antara oksigen dari alveoli ke kapiler paru-paru dan karbondioksida dari kapiler alveoli. Proses pertukaran ini dipengaruhi oleh beberapa faktor yaitu luas permukaan paru, tebal membrane respirasi, perbedaan tekanan dan 
konsentrasi oksigen serta afinitas gas ( kemampuan untuk menembus dan saling mengikat hemoglobin (HB).

c. Transportasi

Transportasi gas merupakan proses pendistribusian antara oksigen kapiler kejaringan tubuh dan karbondioksida jaringan tubuh ke kapiler. Pada proses ini oksigen akan berikatan dengan $\mathrm{Hb}$ membentuk oksihemoglobin (97\%) dan larut dalam plasma (3\%). Sedangkan Karbondioksida akan berikatan dengan $\mathrm{Hb}$ membentuk karbonminohemoglobin (30\%), larutdalam plasma (5\%) dan sebagian menjadi $\mathrm{HCO}_{3}$ berada dalam darah (65\%)

2. Pola pernafasan manusia

Frekuensi pernafasan manusia berbeda pada masing-masing kelompok usia, pada usia bayi fekruensi pernafasannya lebih cepat dari kelompok usia yang lain.

Tabel 5.3 Pola pernafasan manusia berdasarkan usia

\begin{tabular}{|l|c|}
\hline \multicolumn{1}{|c|}{ Kelompok Usia } & Rata-rata Pernafasan /menit \\
\hline Bayi baru lahir \& bayi & $30-60$ \\
\hline 1-5 Tahun & $20-30$ \\
\hline 6 - 10 Tahun & $18-26$ \\
\hline 10 Tahun-Dewasa & $12-20$ \\
\hline Dewasa tua (>60 tahun) & $16-25$ \\
\hline
\end{tabular}

3. Faktor yang mempengaruhi kebutuhan oksigen

a. Syafaraf otonom, rangsangan saraf simpatis dan parasimpatis mempengaruhi kemampuan untuk berdilatasi dan konstriksi

b. Hormonal dan obat, semua hormone termasuk derivat katekolamin dan nafaspat melebarkan saluran pernafasan.

c. Alergi pada saluran pernafasan, balrdi debu, bulu binatang, serbuk benang sari bunga, makanan dan lain-lain dapat menyebabkan bersin jika rangsangan didaerah nasal, batuk apabila rangsangan saluran nafas atas 
d. Faktor pekembangan mempengaruhi jumlah kebutuhan oksigen karena usia organ dalam tubuh seiring dengan uasia perkembangan anak.

e. Faktor lingkungan, misalnya ketinggian dan suhu tubuh, kondisi tersebut memerlukan adaptasi.

f. Faktor perilaku, perilaku dalam mengkonsumsi makanan, aktivitas dapat meningkatkan kebutuhan oksigenasi.

4. Beberapa Gangguan/masalah kebutuhan oksigen

a. Hipoksia

Merupakan kondisi tidak tercukupinya pemenuhan kebutuhan oksigen dalam tubuh akibat defisiensi oksigen atau peningkatan penggunaan oksigen di tingkat sel, sehingga bisa muncul kulit kebiruan (cyanosis)

b. Perubahan pola pernafasan

1) Takipnea merupakan pernafasan cepat lebih dari 24x/menit.

2) Bradipnea merupakan pernafasan yang lambat kurang lebih 10x/menit.

3) Hiperventilasi merupakan pernafasan cepat dan dalam

4) Kusmaull merupakan pola pernafasan cepat dan dangkal

5) Hipoventilasi merupakan upaya tubuh mengeluarkan karbodioksida dengan cukup pada saat ventilasi alveolar.

6) Dispneamerupakan sesak dan berat saat pernafasan.

7) Orthopnea merupakan kesulita bernafas kecuali dalam posisi duduk/berdiri

8) Cheyne stokes merupakan siklus pernafasan yang amplitudonya mula-mula naiak kemudian menurun dan berhenti, lalu pernafasan dimulai lagi dari siklus baru. Periode apnea berulang secar teratur.

9) Pernafasan paradoksial merupakan pernafasan dimana dinding paru-paru bergerak berlawanan arah dari keadaan normal. 
10) Biotl merupakan pernafasan yang mirip chynestoke, tetapi amplitudonya tidak teratur.

11) Stridor merupakan pernafasan yang bising akibat penyempitan saluran pernafasan

c. Obstruksi jalan nafas

Suatu kondisi pada individu dengan pernafasan yang mengalami ancaman, terkait ketidakmampuan batuk secara efektif.

d. Pertukaran gas

Suatu kondisi pada individu yang mengalami penurunan gas, baik oksigen maupun karbond loksida, antara alveoli paru-paru dan sistem vaskuker.

5. Bahaya pemberian oksigen

Pemberian $\mathrm{O} 2$ bukan hanya memberiakan efek terapi tetapi juga dapat menimbulkan efek merugikan, antara lain :

a. Kebakaran

O2 bukan zat pembakar tetapi 02 dapat memudahkan terjadinya kebakaran, oleh karena itu klein dengan terapi pemberian 02 harus menghindari : Merokok, membukan alat listrik dalam area sumber O2, menghindari penggunaan listrik tanpa "Ground".

b. Depresi Ventilasi

Pemberian $\mathrm{O} 2$ yang tidak dimonitor dengan konsentrasi dan aliran yang tepat pada klien dengan retensi $\mathrm{CO} 2$ dapat menekan ventilasi

c. Keracunan $\mathrm{O} 2$

Dapat terjadi bila terapi $\mathrm{O} 2$ yang diberikan dengan konsentrasi tinggi dalam waktu relatif lama. Keadaan ini dapat merusak struktur jaringan paru seperti atelektasi dan kerusakan surfaktan. Akibatnya proses difusi di paru akan terganggu

\section{Pratik pemenuhan kebutuhan oksigen}

1. Pemberian Nebulizer

Persiapan Alat

- Set nebulizer + Sungkup/ oral/ hirup 
- WFI (Water for Injection) dan obat yang akan dipakai (Fentolin)

- Bengkok

- Spuit 3 cc

- Handschoon Disposable dlm kom

- Handuk sekali pakai

Persiapan Pasien

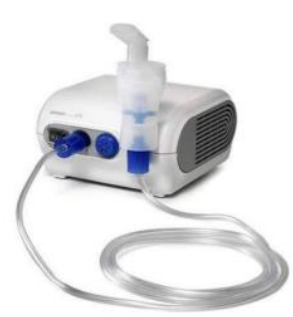

Gb. 5.2 Alat Nebulizer

- Memberitahukan pasien/kelu akan dilakukan

- Pengaturan posisi

Prosedur kerja

- Jelaskan prosedur yang akan dilakukan kepada pasien

- Monitor denyut nadi sebelum dan sesudah pengobatan khususnya pada pasien yang menggunakan bronchodilator

- Atur posisi pasien senyaman mungkin, paling sering dalam posisi semi fowler

- Mencuci tangan, mengeringkan dengan handuk sekali pakai, kemudian memakai handschoon disposable

- Masukkan obat (Fentolin) dan WFI dengan spuit (dosis obat yang diberikan sesuai dengan advice dokter)

- Hubungkan nebulizer (yang telah diisi fentolin dan WFI) Intruksikan pasien untuk buang nafas

- Minta pasien untuk mengambil nafas melalui hidung

- Observasi pengembangan paru/ dada pasien

- Minta pasien untuk bernafas perlahan-lahan dan dalam setelah seluruh obat diuapkan

- Selesai tindakan anjurkan pasien untuk batuk setelah tarik nafas dalam beberapa kali

- Mencuci tangan

- Catat respon pasien dan tindakan yang telah dilakukan

Hal-hal yang perlu diperhatikan : 
- Perlakukan pasien secara hati-hati

- Saat awal tindakan pasien perlu di dampingi sampai terlihat tenang

2. Menghisap Lendir

Persiapan alat

- Alat penghisap / Suction dgn botol berisi larutan desifektan

- Kateter steril / sesuai dengan ukuran dalam kemasan steril

- Bak instrumen steril, berisi : Kassa steril Handschoon steril

- Pelumas larut air (gel/ lubrican)

- Selimut atau handuk

- Masker wajah

- Air DTT/ larutan NaCL dalam kom

- Handuk cuci tangan

- Tissue

Persiapan Pasien

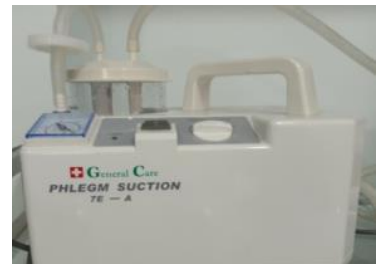

Gb. 5.3 Alat Penghisap

- Jelaskan prosedur pada klien

Prosedur Kerja

- Siapkan peralatan di samping klien

- Cuci tangan

- Posisikan pasien dengan tepat :

$\checkmark$ Bila sadar $\rightarrow$ baringkan pasien pada posisi semi fowler dengan kepala miring ke satu sisi untuk penghisapan oral. Kepala ekstensi untuk penghisapan nasal.

$\checkmark$ Bila pasien tidak sadar $\rightarrow$ baringkan pasien posisi lateral menghadap pada petugas untuk penghisapan oral / nasal

- Tempatkan handuk pada bantal atau dibawah dagu pasien 
- Pilih tekanan dan tipe unit penghisapan yang tepat

- Kenakan handschoon steril pada tangan yang dominan

- Gunakan tangan yang telah menggunakan sarung tangan, sambungkan kateter ke alat penghisap

- Pakai handschoon di lengan lainnya

- Perkirakan jarak antara daun telinga pasien dan ujung hidung dan letakkan ibu jari dan jari telunjuk dari tangan yang telah menggunakan handschoon

- Basahi ujung kateter dengan pelumas larut air. Pasang penghisap dengan ujungnya terletak dalam larutan

- Menghisap :

$\checkmark$ Orofaring : dengan perlahan masukkan kateter ke dalam satu sisi mulut pasien dan arahkan ke orofaring, jangan lakukan penghisapan selama pemasangan.

$\checkmark$ Nasofaring : dengan perlahan masukkan kateter ke salah satu lubang hidung. Arahkan ke arah medial sepanjang dasar rongga hidung .

- Sumbat port penghisap dengan ibu jari petugas dengan perlahan, rotasi kateter saat petugas menariknya. Keseluruhan prosedur tidak boleh lebih dari 15 detik

- Bilas kateter dengan air DTT dengan meletakkan dalam air DTT dan lakukan penghisapan kembali

- Bila pasien tidak mengalami distres, biarkan istirahat selama 20 - 30 detik sebelum memasukkan ulang kateter

- Bila pasien mampu, minta pasien untuk bernafas dalam

- Hisap secret pada mulut atau dibawah lidah setelah penghisapan

- orofaring / nasofaring 
- Buang kateter dengan pembungkusnya dalam tangan petugas yang mengenakan handschoon untuk membungkus kateter

- Siapkan peralatan untuk penghisapan berikutnya

- Catat pada catatan perawatan : jumlah, konsistensi, warna dan bau secret serta respon pasien terhadap prosedur

3. Pemberian Oksigen

Persiapan Alat:

- Nasal kanul/ masker

- Tabung oksigen lengkap dengan flow meter dan Humidifier

- Plester

- Gunting Plester

- Kassa Steril dlm kom steril

- Bengkok

Persiapan Pasien

- Penjelasan prosedur.

- Mengatur posisi pasien dengan posisi semi flower.

Prosedur kerja

- Mencuci tangan.

- Atur peralatan oksigen dan humidifier

- Putar oksigen sesuai dengan terapi dan pastikan alat dapat berfungsi

$\checkmark$ Cek oksigen dapat mengalir secara bebas melalui selang. Seharusnya tidak ada suara pada selang dan sambungan tidak bocor. Seharusnya ada gelembung udara pada humidifier saat oksigen mengalir lewat air

$\checkmark$ Atur oksigen dengan flowmeter sesuai dengan advice 
- Tempatkan nasal kanul/ masker ke arah wajah pasien dan letakkan dari hidung ke bawah

- Pastikan posisi masker tepat, jika menggunakan kateter ukur dulu jarak hidung dengan telinga

- Agar posisi masker/nasal kanule tepat pada posisinya fiksasi dengan mengikat elastis band melingkar dikepala pasien.

- Secara teratur lakukan pengecekan :

$\checkmark$ Setiap 30 menit cek flowmeter dan ukuran air dalam humidifier

$\checkmark$ Air humidifier dipertahankan tinggihnya

$\checkmark$ Pastikan petunjuk keamanan diikuti

- Lakukan pencatatan

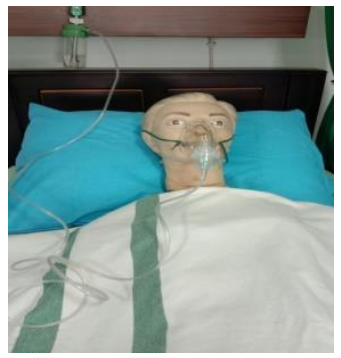

Gb. 5.4 Pemberian oksigen dengan masker

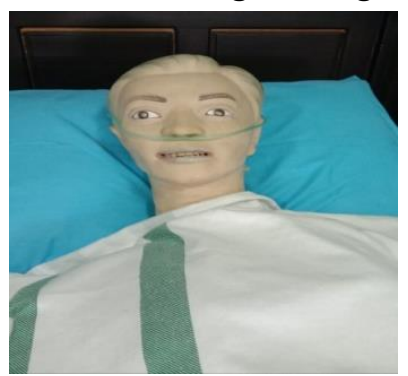

Gb. 5.5 Pemberian oksigen dengan kanul

\section{Kebutuhan nutrisi}


Nutrisi merupakan proses pemasukan dan pengolahan zat makanan oleh tubuh yang bertujuan mennghasilkan energy dan digunakan dalam aktivitas tubuh.

1. Kebutuhan nutrisi berhubungan dengan saluran pencernaan meliputi: Mulut, lambung, usus halus, usus besar sedangkan organ aksesori: Hati, kantong empedu dan pankreas

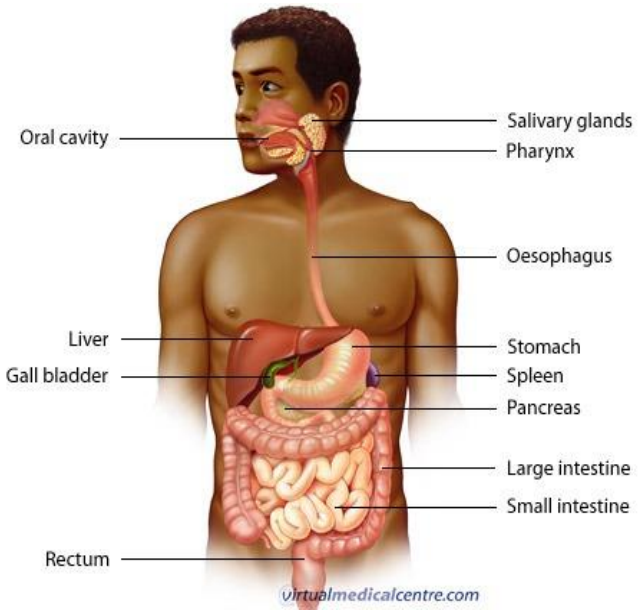

Gb. 5.6 sistem pencernaan

Sumber : https://healthengine.com.

2. Nutrien

Merupakan zat gizi yang terdapat dalam makanan. Zat gizi antara lain :

a. Karbohidrat

Karbohidrat merupakan zat gizi yang berupa amilum, dimulut amilum diubah menjadi maltose oleh enzim ptyalin dalam air ludah. Zat tersebut kemudian diteruskan kelambung, ke usus duabelas jari dan sisa amilum yang belum diubah menjadi maltose oleh amilase pankreas diubah seluruhnya menjadi maltose. Kemudian di usus halus oleh enzim maltase mengubah malsa menjadi dua molekul glukosa, enzim sukrase mengubah sukrosa menjadi fruktosa dan 
glukosa, dan enzim lakrase mengubah laktosa menjadi glukosa dan galaktosa. Penyerapan karbohidrat yang dikonsumsi ditemukan dalam 3 bentuk polisakarida, disakarida dan monosakarida.

b. Lemak

Pencernaan lemak dimulai dalam lambung karena dimulut tidak ada enzim pemecah lemak. Enzim lipase dalam lambung mengubah sebagian lemak menjadi asam lemak dan gliserin, kemudan diangkut melalui getah bening dan selanjutnya masuk kedalam peredaran darah kemudian ke hati. Sintetis kembali lemak menjadi seperti aslinya terjadi dal am getah bening.

c. Protein

Protein diubah menjadi albuminosa dan pepton oleh enzim protease yang berupa pepsin dilambung. Selanjutnya diubah menjadi asam amino dan diserap oleh dinding usus.

d. Mineral

Mineral tidak membutuhkan pencernaan. Mineral hadir dalam bentuk tertentu sehingga tubuh mudah memprosesnya dan mudah diserap dengan mudah melalui dinding usus halus secara difusi pasif maupun transport aktif. Mekanisme traspor aktif diatur oleh hormone.

Jenis mineral yaitu kalsium, kalium, fosfor, yodium, besi, magnesium dan zinc.

e. Vitamin

Proses penyerapan vitamin dapat dilakukan dengan difusi sederhana. Vitamin yang larut dalam lemak (A,D,E,E, dan K) diserap oleh sistem transport aktif yang membawa lemak keseluruh tubuh. Sedangkan vitamin yang larut dalam air ( B dan C) mempunyai beerapa variasi mekanisme transport aktif.

\section{f. Air}

Air merupakan zat gizi yangb paling mendasar.Tubuh manusia terdiri 50-70\% air. Asupan air secara teratur sangat penting dibandingkan 
asupan nutrisi lain. Bayi memiliki proporsi air yang lebih besar daripada orang dewasa, semakin tua seseorang maka proporsi air tubuhnya semakin berkurang.

3. Masalah Kebutuhan Nutrisi
a. Kekurangan nutrisi
b. Kelebihan nutrisi
c. Obesitas
d. Mal nutrisi
e. Diabetes mellitus
f. Hipertensi
g. Penyakit jantung coroner
h. Kanker
i. Anoreksia nervosa

4. Praktik pemenuhan kebutuhan nutrisi pasien

a. Pemasangan dan pelepasan NGT

Persiapan Alat

- Selang NGT No. 14/ 16 (untuk anak - anak lebih kecil ukurannya)

- Gel / pelumas

- Bak instrumen steril, berisi: Sarung tangan steril, Tounge spatel lidah

- Kassa steril

- Spuit $60 \mathrm{cc}$

- Spuit 3 cc

- Stetoskop

- Cotton bud

- Plester + Gunting plester

- Segelas air

- Handuk ukuran sedang

- Tissue

- Duk bersih dan pengalas

- Baskom berisi larutan klorin 0,5\% 
- Bengkok

- Korentang + tempat

Persiapan Pasien

- Jelaskan prosedur tindakan

Prosedur Kerja

- Mendekatkan peralatan

- Membantu pasien dalam posisi fowler / semifowler

- Mencuci tangan

- Menggunakan cotton bud bersihkan daerah hidung dan alasi dada pasien dengan handuk.

- Masukan slang NGT dalam bak instrument setelah dibuka dari bungkusnya.

- Pakai sarung tangan steril

- Tentukan ukuran slang dari epigastrium sampai hidung, kemudian dibengkokkan ke telinga dan beri tanda batasnya dengan plester.

- Ujung selang $10-20 \mathrm{~cm}$ lumasi dengan jelly

- Anjurkan pasien untuk tidak tegang dan nafas seperti biasa. Masukan NGT pelan-pelan 5-10 cm, anjurkan pasien untuk menelan.

- Masukan selang sampai batas yang ditandai dan Mengecek ketepat

$\checkmark$ Rendam ujung pipa kedalam gelas yang berisi air, buka klem, jika ada gelembung udara berarti posisi selang sudah pas masuk dalam lambung.

$\checkmark$ Gunakan spuit untuk memasukan udara $3 \mathrm{cc}$, dalam waktu yang bersamaan dengarkan dengan stetoskop didaerah lambung, bila terdengar suara artinya posisi sudah tepat.

- Fiksasi dengan menggunakan plester pada daerah hidung

- Bantu pasien untuk kembal 
- Rapikan dan bereskan lat

- Dekontaminasi sarung tangan

- cuci tangan

- Evaluasi respon pasien

- Dokumentasi tindakan yang telah dilakukan

\section{Catatan :}

- Berhenti memasukkan selang jika pasien batuk, bersin, kemudian lanjutkan lagi memasukkan.

- Pada saat memasukan selang ke hidung ada tahanan, tarik selang pelan-pelan dan masukan lagi jika tetap ada tahanan ganti hidung yang lain.

- Apabila pasien terlihat ingin muntah tarik selang dan observasi tenggorokan kemudian masukakan selan secara perlahan.

Pelepasan / Aff NGT

- Cuci tangan

- Dekatkan semua peralatan

- Pakai sarung tangan

- Basahi plester yang menempel pada kulit kemudian lepas

- Letakkan kasa di bawah selang yang dekat dengan hidung

- Tarik keluar selang secara perlahan

- Masukkan selang ke dalam larutan klorin

- Rapikan semua peralatan

- Dekontaminasi alat dan sarung tangan

- Cuci tangan

- Lakukan dokumentasi

b. Pemberian makan melalui NGT

Persiapan alat

- Sarung tangan disposable

- Makanan cair / obat sesuai kebutuhan 
- Air matang dalam gelas

- Corong makanan

- Spuit 5/10 cc

- Tissu

- Perlak + pengalas

- Bengkok

Prosedur Kerja

- Menjaga privasi pasien dengan menutup tirai / pintu ruangan

- Menjelaskan tujuan dan prosedur tindakan pada keluarga / pasien

- Mengatur posisi pasien dalam posisi semi fowler/fowler (jika tidak ada kontra indikasi)

- Mencuci tangan

- Memakai sarung tangan

- Memasang pengalas di atas dada

- Memastikan letak NGT dengan cara aspirasi isi lambung menggunakan spuit

- Memasang corong

- Memasukkan air matang, membuka klem, tinggikan 30 $\mathrm{cm}$, sebelum habis klem kembali.

- Memasukkan makanan cair, membuka klem, meninggikan $30 \mathrm{~cm}$, klem kembali sebelum habis

- Memasukkan air matang, membuka klem, tinggikan 30 $\mathrm{cm}$, sebelum air habis klem kembali

- Menutup ujung NGT dengan spuit/klem

- Membersihkan sisa makanan pada pasien

- Merapikan pasien 


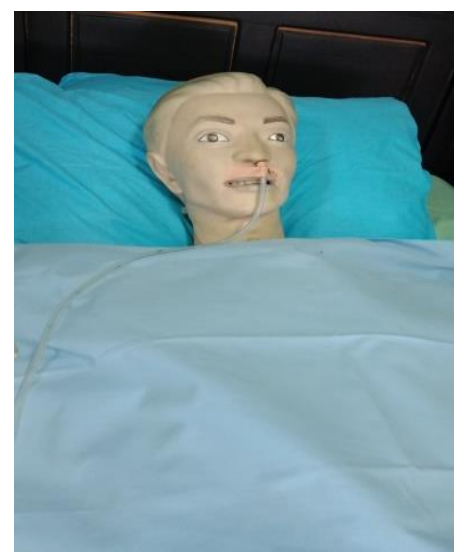

Gb. 5.8 Pemasangan NGT

\section{Kebutuhan isirahat dan tidur}

\section{Istirahat}

a. Pengertian istirahat

Istirahat merupakan keadaan yang rileks tanpa adanya emosional dan bukan hanya dalam keadaan tidak beraktifitas, melainkan juga berhenti sejenak. Istirahat berarti menyegarkan diri ataua diam setelah melakukan kerja keras.

b. Karakteristik istirahat

Ada 6 karakteristik istirahat yaitu:

1) Merasakan tidak ada masalah yang tidak bisa diatasi

2) Merasa diterima

3) Tahu apa yang sedang terjadi

4) Bebas dari gangguan ketidaknyamanan

5) Memiliki perasaan puas atas aktifitas yang memiliki tujuan

6) Disaat membutuhkan tahu adanya bantuan

\section{Tidur}

\section{a. Pengertian tidur}

Tidur merupakan suatu kondisi tidak sadar di mana individu dapat dibangunkan oleh stimulus atau sensori yang sesuai. 
Beberapa ahli tidur yakin bahwaperasaan tenaga yang pulih ini menunjukkan bahwa tidur memberikan waktu untuk perbaikan dan penyambuhan sistem tubuh untuk periode keterjagaan yang berikutnya.

\section{b. Fisiologi tidur}

Fisiologis tidur merupakan pengaturan tidur yang melibatkan hubungan mekanisme serebral secara bergantian agar mengaktifkan dan menekan pusat otak agar dapat tidur dan bangun.

Sistem pengaktivasi retikularis ( Reticularis activating System) merupakan salah satu pengatur aktivitas tidur dengan mengatur mengatur seluruh tingkatan kegiatan susunan saraf pusat, Pada kondisi sadar sistem ini mengeluarkan katekolamin dan RAS memberikan rangsangan visual, pendengaran, nyeri dan perabaan , emosi dan proses berfikir. sedangkan pada saat tidur mengeluarkan Serotonin dari sel khusus yang berada di spon dan batang otak tengah yaitu bulbar synchronizing regional (BSR). Pada saat bangun tergantung dari keseimbangan impuls yang diterima di pusat otak dan sistem limbik. Jadi sistem pada batang otak yang mengatur siklus atau perubahan dalam tidur adalah RAS dan BSR.

\section{c. Jenis-jenis tidur}

Ada 2 jenis tidur berdasarkan prosesnya yaitu:

1) Tidur gelombang lambat (slow wave sleep)/ Non Rapid Eye Movement (NREM)

Jenis tidur ini dikenal dengan tidur dalam, istirahat penuh gelombang otak lebih lambat atau dikenaltidur nyenyak. Ciri-ciri dari tidur ini adalah menyegarkan, tanpa mimpi, keadaan istirahat penuh, tekanan darah menurun, pernafasan menurun, metabolism menurun

Tahap tidur NREM ada 4 tahap, tahap 1-2 tahap tidur ringan dan tahap 3-4 tahap tidur dalam.

2) Tidur Paradoks/tidur Rapid Eye Movement (REM) 
Tidur jenis ini berlangsung pada tidur malam yang terjadi se lama 520 menit., rata-rata timbul 90 menit Periode pertama terjadi selama 80-100 menit. Namun apabila kondisi orang sangat lelah maka awal tidur sangat cepat bahkan jenis tidur ini tidak ada. Ciri-ciri tidur REM adalah sebagai berikut:

a) Biasanya disertai dengan mimpi aktif

b) Lebih sulit dibangunkan dari pada tidur nyenyak NREM

c) Tonus otot sangat tertekan, menunjukkan inhibisi kuat proyeksi spinal atas (RAS).

d) Frekuensi jantung dan pernafasan menjadi tidak teratur

e) Pada otot perifer terjadi pergerakan tidak teratur

f) Mata cepat tertutup dan terbuka, nadi tidak teratur, tekanan darah dan metabolisme meningkat.

g) Tidur ini penting untuk keseimbangan mental emosi, memori, proses berfikir dan adaptasi.

\section{d. Fungsi dan tujuan tidur}

Fungsi dan tujuan tidur untuk mejaga keseimbangan mental, emosional dan kesehatan.

Secara umum terdapat 2 efek fisiologis tidur

1) Efek pada sistem saraf yang diperkirakan dapat memulihkan kepekaan normal dan keseimbangan diantara susunan saraf.

2) Efek pada struktur tubuh yang dapat memulihkan kesegaran dan fungsi organ dalam tubuhdan, karena selama tidur telah terjadi penurunan aktivitas organorgan tersebut.

\section{e. Kebutuhan tidur pada manusia}

Kebutuhan tidur berdasarkan tingkat perkembangan berbeda dari masing-masing individu yang dapat dilihat pada table berikut: 
Tabel 5.4 kebutuhan tidur berdasarkan usia

\begin{tabular}{lll}
\hline Umur & Tingkat Perkembangan & Kebutuhan tidur \\
\hline 0 -1 Bulan & Bayi baru lahir & $14-18$ jam/hari \\
1-18 Bulan & Masa bayi & $12-14$ jam/hari \\
18 bln-3 Th & Masa anak & $11-12$ jam/hari \\
3-6 Tahun & Masa prasekolah & 11 jam/hari \\
6-12 Tahun & Masa sekolah & 10 Jam/hari \\
12 -18 Tahun & Masa remaja & 8,5 jam/hari \\
18-40 Tahun & Ma dewasa & $7-8$ jam/hari \\
40-60 Tahun & Paruh baya & 7 jam / hari \\
Lebih 60 Th & Masa dewasa tua & 6 jam/hari \\
\hline
\end{tabular}

\section{f. Faktor-faktor yang mempengaruhi tidur}

1) Penyakit

Seseorang yang menderita penyakit dapat menimbulkan gangguan pada tidurnya, Orang sakit perlu waktu tidur lebih lama. Keadaan sakit dapat juga menyebabkan orang kurang tidur bahkan tidak bisa tidur.

2) Lingkungan

Kondisi lingkungan yang nyaman dan aman dapat mempercepat proses terjadinya tidur, Sebaliknya lingkungan yang kurang nyaman, berisik dan ventilasi kurang baik dapat mengganggu tidur seseorang.

3) Latihan dan Kelelahan

Keletihan akibat aktivitas yang tinggi memerlukan lebih banyak tidur untuk menjaga keseimbangan energy yang telah dikeluarkan. Orang yang kelelahan lebih cepat tidur karena tahap tidur NREM diperpendek.

4) Gaya Hidup

Orang yang bekerja dengan jam kerja yang berubah-rubah dapat mempengaruhi waktu tidur.

5) Stres Emosional

Kondisi stres menyebabkan ketegangan jiwa dan mengalami kegelisahan sehingga sulit untuk tidur. 
6) Stimulan dan Alkohol

Kafein yang yerdapat dalam minuman bisa mengganggu susunan safraf pusat, sehingga mengganggu tidur. Konsumsi alkohol yang berlebihan menyebabkan gangguan pada siklus tidur REM.

7) Nutrisi

Terpenuhinya kebutuhan nutrisi mempengaruhi proses tidur, sedangkan kebutuhan gizi yang kurang menyebabkan sulit tidur.

8) Merokok

Kandungan nikotin dalam rook menyebabkan kesulitan untuk tidur.

9) Medikasi

Terdapat beberapa obat -obatan berefek pada kualitas tidur.

10) Motivasi

Dorongan atau keinginan seseorang untuk tidur, sehingga dapat mempengaruhi proses tidurdan sebaliknya keinginan untuk tidak tidur dapat menimbulkan gangguan pada proses tidur.

\section{g. Gangguan yang umum terjadi}

1) Insomnia

Kebutuhan tidur secara kualitas dan kuantitas tidak terpeuhi.

2)Parasomnia

Kumpulan beberapa penyakit yang dapat mengganggu pola tidur, misalnya somnabolisme (berjalan-jalan dalam tidur) yang banyak terjadi pada anak-anak.

3)Hipersomnia

Tidur yang berlebihan, lebih dari 9 jam pada malam hari bisa disebabkan masalah psikologis, depresi, gangguan susunan saraf pusat.

\section{4)Narkolepsi}

Keadaan tidur yang tidak dapat dikendalikan, seperti tidur saat seseorang tidur dalam keadaan berdiri, mengemudikan kendaraan atau ditengah suatu pembicaraan.

5) Apnea Saat Tidur dan Mendengkur 
Mendengkur tidak termasuk gangguan tidur, tetapi mendengkur yang disertai dengan keadaan apnea dapat menjadi masalah.

6) Enuresa

Mengompol atau BAK yang tidak disadari diwaktu tidur.

\section{E. Kebutuhan mekanik tubuh, Posisi, ambulasi dan mobilitas}

Mekanika tubuh merupakan usaha koordinasi dari musculoskeletal dan sistem saraf untuk mempertahankan keseimbangan yang tepat. Mekanika tubuh cara menggunakan tubuh secara efisien yaitu tidak banyak mengeluarkan tenaga.

\section{Prinsip mekanika tubuh}

1. Gravitasi

Memandang gravitasi sebagai sumbu dalam pergerakan tubuh, ada 3 faktor

a. Pusat gravitasi yaitu titik yang berada di pertengahan tubuh.

b. Garis gravitasi merupakan garis imajiner vertical melalui pusat gravitasi

c. Dasar dari tumpuhan merupakan dasar tempat seseorang dalam posisi istirahat untuk menopang/menahan tubuh.

2. Keseimbangan.

Keseimbangan dapat dicapai dengan cara mempertahankan posisi garis gravitasi diantara pusat gravitasi dan garis tumpuhan.

3. Berat.

Berat atau bobot benda yang akan diangkat karena berat benda tersebut akan mempengaruhi mekanika tubuh.

\section{Pergerakan dalam mekanika tubuh.}

Mekanika tubuh dan ambulasi merupakan bagian dari kebutuhan aktifitas manusia.

1. Gerakan (Ambulating)

Keseimbangan tubuh dapat dipertahankan dengan gerakan yang benar. 
2. Menahan (Squatting)

Dalam menahan dibutuhkan dasar tumpuhan yang tepat agar tidak terjadi kelainan pada tubuh dan memudahkan gerakan.

3. Menarik (Pulling)

Menarik dengan tepat dapat memudahkan pemindahan bendah.

4. Mengangkat (Lifting).

Mengangkat merupakan cara pergerakan yang menggunakan daya tarik ke atas Ketika melakukan gerakan ini gunakan otot-otot besar dari tumit, paha bagian atas, kaki bawah, perut dan pinggul untuk mengurangi rasa sakit pada daerah tubh bagian belakang.

5. Memutar (Pivoting)

Memutar merupakan gerakan untuk berputarnya anggota tubuh dengan bertumpuh pada tulang belakang.

\section{Faktor-Faktor Yang Mempengaruhi Mekanika Tubuh}

1. Status kesehatan

Kondisi sakit menyebabkan berkurangnya kemampuan untuk melakukan aktifitas.

2. Nutrisi

Nutrisi yang kurang menyebabkan kelemahan otot dan memudahkan terjadinya penyakit.

3. Emosi.

Seseorang yang mengalami perasaan tidak aman, tidak semangat dan harga diri yang rendah akan mudah mengalami perubahan dalam mekanika tubuh dan ambulasi.

4. Situasi dan Kebiasaan

Situasi dan kebiasaan yang dilakukan seseorang misalnya sering mengangkat benda-benda yang berat menyebabkan perubahan mekanika tubuh dan ambulasi.

5. Gaya Hidup

Perubahan pola hidup seseorang menyebabkan stres dan kemungkinan besar akan menimbulkan kecerobohan dalam 
beraktifitas, sehingga akan mengurangi energy yang telah dikeluarkan.

6. Pengetahuan

Pengetahuan yang baik terhadap mekanika tubuh akan mendorong seseorang untuk menggunakan secara benar, sehingga mengurangi energy yang telah dikeluarkan.

\section{Dampak Mekanika Tubuh}

Mekanika tubuh yang tepat bisa mencegah penggunaan energi secara berlebihan. Bisah salah bisa berakibat

1. Menimbulkan ketegangan sehingga mudah lelah dan terjadi gangguan musculoskeletal

2. Bisa terjadi risiko kecelakaan pada musculoskeletal.

Pengaturan Posisi

1. Posisi Supinasi

Tujuan :

- Untuk klien post operasi dengan menggunakan anastesi spinal.

- Untuk mengatasi masalah yang timbul akibat pemberian posisi pronasi yang tidak tepat.

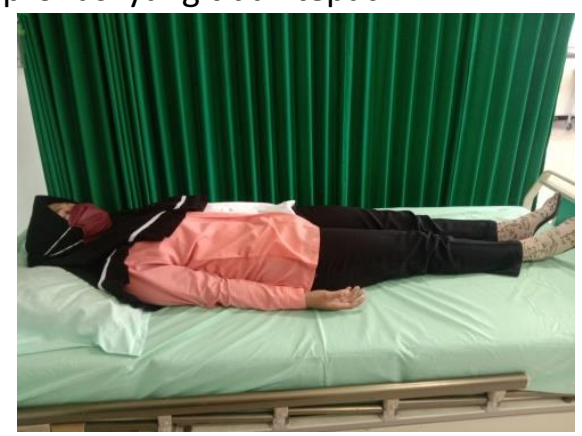

Gb. 5.9 Posisi supinasi

2. Posisi fowler

Posisi setengah duduk atau duduk, dimana bagian kepala tempat tidur lebih tinggi/ dinaikkan.

Tujuan : 
- Mempertahankan kenyamanan dan menfasilitasi fungsi pernafasan pasien

- Melaksanakan aktifitas makan, membaca dan lain-lain.

Posisi dimana klien berbaring pada posisi pertengahan antara posisi lateral dan posisi pronasi. Posisi ini lengan bawah ada di belakang tubuh klien, sementara lengan didepan tubuh klien.

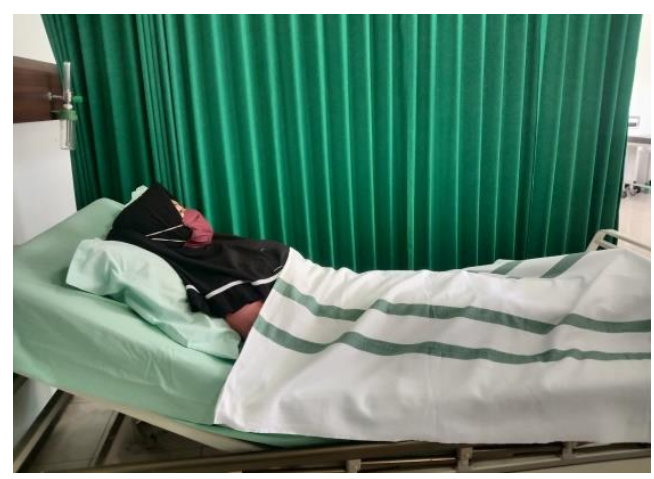

Gb. 5.10 Posisi fowler

3. Posisi Sim

Tujuan :

- Untuk memfasilitasi drainase dari mulut klien yg tidak sadar

- Mengurangi penekanan pada sakrum dan trokhanter besar pada klien yg mengalami paralisis

- Untuk mempermudah pemeriksaan dan perawatan pada area perineal. 


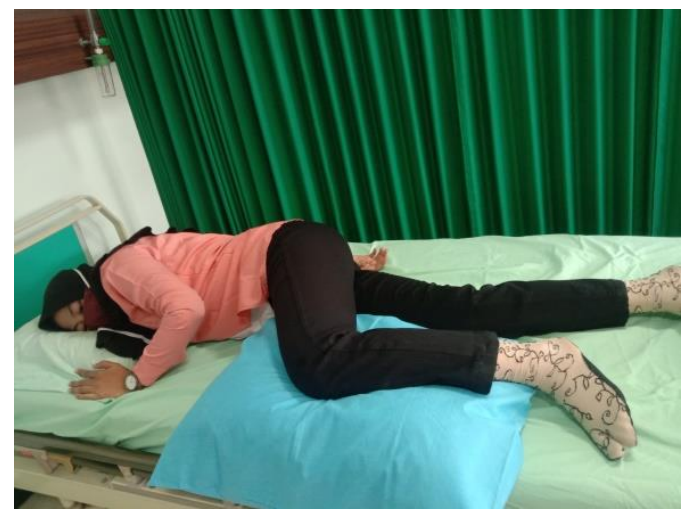

Gb. 5.11 Posisi Sim

4. Posisi Trendelenburg

Posisi pasien berbaring di tempat tidur dengan bagian kepala lebih rendah daripada bagian kaki.

Posisi Lithotomi

Tujuan :

- Posisi ini dilakukan untuk melancarkan peredaran darah ke otak

- Posisi berbaring terlentang dengan mengangkat kedua kaki dan menariknya ke atas bagian perut

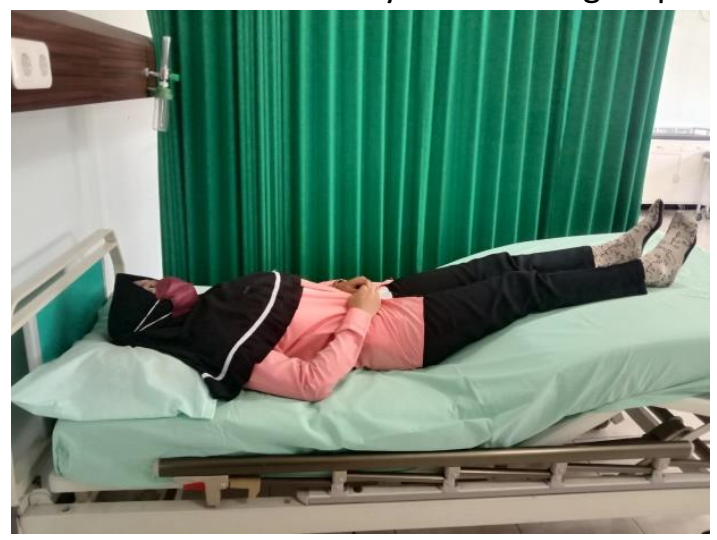

Gb. 5.12 Posisi Trendelenburg 


\section{Posisi Lithotomi}

Posisi berbaring terlentang dengan mengangkat kedua kaki dan menariknya ke atas bagian perut

\section{Tujuan:}

Untuk memeriksa genetalia pada proses persalinan dan memasang alat kontrasepsi (IUD)

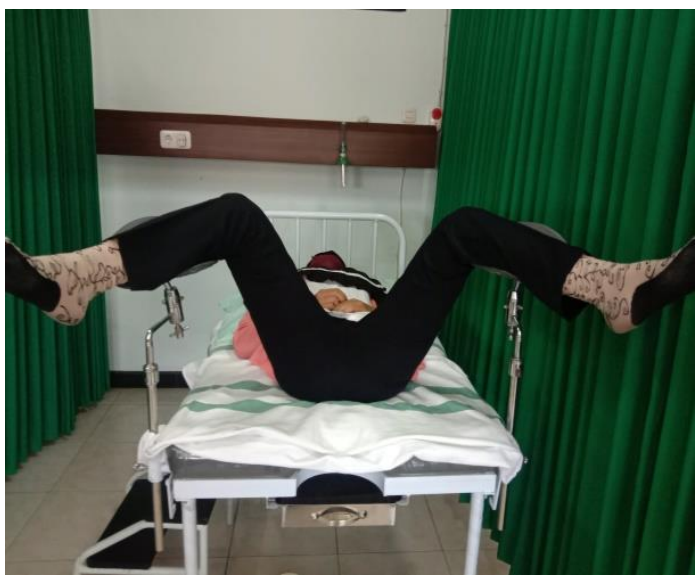

Gb. 5.13 Posisi Lithotomi

\section{Posisi Dorsalrecumbent}

Posisi supinasi dimana kedua kaki menekuk atau fleksi diatas tempat tidur.

Tujuan : Melaksanakan pemeriksaan dalam, vulva hygiene dan menolong persalinan 


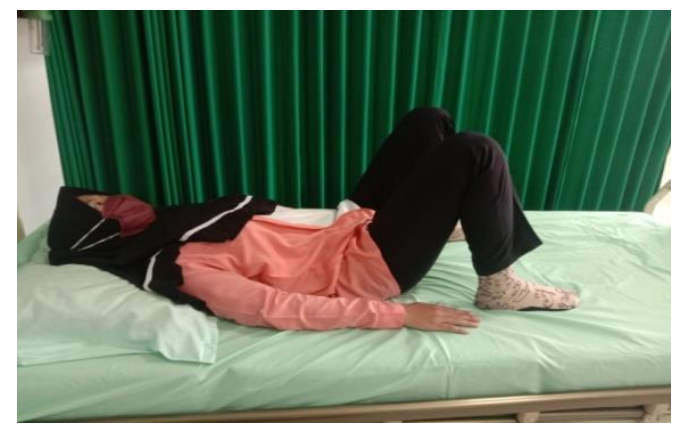

Gb. 5.14 Posisi Dorsalrecumbent

7.Posisi Genu Pektoral/Knee Chest

Posisi menungging dengan kedua kaki ditekuk dan dada menempel pada bagian alas tempat tidur

Tujuan:

- Untuk memeriksa daerah rectum dan sigmoid

- Membantu reposisi letak sungsang dalam kehamilan

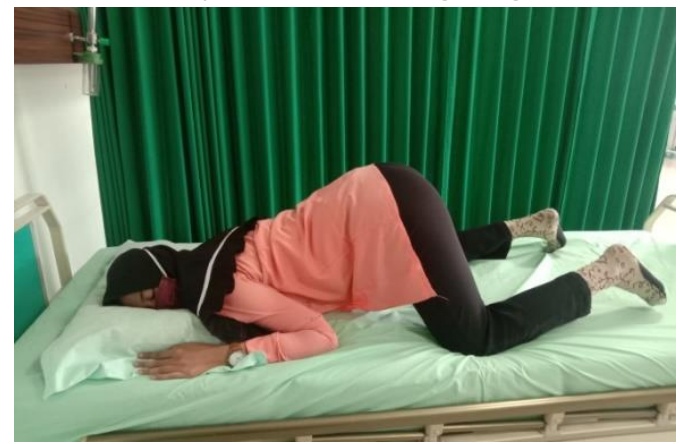

Gb. 5.15 Posisi Genu Pektoral/Knee Chest

\section{Posisi Pronasi}

Suatu posisi dimana pasien berbaring tengkurap dengan kedua tangan disamping dan kpala menoleh kesamping.

Tujuan :

Untuk tindakan pungsi lumbal, mengurangi tekanan pada daerah punggung dan panggul. 


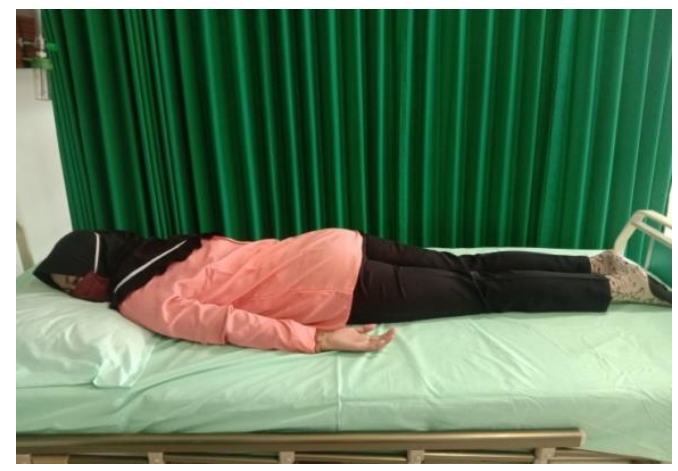

Gb. 5.16 Posisi Pronasi

Tindakan yang berhubungan dengan ambulasi dan mobilitas

- Latihan Ambulasi

- Duduk ditempat diatas tempat tidur

- Turun dan berdiri

- Membantu berjalan

Membantu Ambulasi dengan Memindahkan Pasien

- Menaikkan posisi klien yang melorot ke atas tempat tidur

- Memindahkan posisi klien di tepi tempat tidur

- Memindahkan klien dari tempat tidur ke kursi roda

- Memindahkan klien dari tempat tidur ke brankart.

\section{F. Kebutuhan Perawatan Diri ( personal hygiene)}

\section{Pengertian}

Suatu tindakan yang dilakukan oleh seseorang untuk menjaga kebersihan dan kesehatan sehingga mendapatkan kesejahteraan fisik maupun psikologis.

\section{Tujuan dari perawatan diri}

a. Menciptakan kenyamanan dan keindahan

b. Dapat mencegah penularan penyakit untuk diri sendiri maupun orang lain. 

c. Menambah kepercayaan diri
d. Menjaga status kesehatan

3. Faktor-faktor yang mempengaruhi perawatan diri klien meliputi:

a. Status kesehatan

Kondisi sakit menyebabkan ketidakmampuan seseorang untuk melakukan perawatan diri secara mandiri, sehingga butuh bantuan orang lain atau petugas kesehatan.

b. Budaya

Budaya yang ada dimasyarakat yaitu kalau sedang sakit tidak boleh mandi nanti sakitnya bertambah parah.

c. Status sosial-ekonomi

Untuk perawatan diri membutuhkan sarana dan prasarana seperti air bersih, sabun dan shampoo, sehingga membutuhkan biaya yang nantinya bisa berpengaruh terhadap kebutuhan perawatan diri yang baik.

d. Tingkat pengetahuan dan perkembangan

Pengetahuan yang baik tentang perawatan diri, maka akan mempengaruhi perilaku seseorang untuk melakukan perawatan diri secara baik dan benar.

e. Cacat fisik atau mental

Kondisi kecacatan fisik dan mental menyebabkan menyebabkan ketidakmampuan seseorang dalam melaksanakan perawatan diri secara mandiri,

\section{f. Praktek sosial}

Pada masa bayi dan anak memperoleh perawatan diri dari orang tua, sedangkan kalau sudah beranjak remaja akan lebih memperhatikan perawatan diri karena dipengaruhi oleh teman sebaya atau pacar.

\section{Jenis perawatan dalam personal hygiene}

a. Perawatan diri pada Kulit

Kulit merupakan bagian penting dari tubuh yang melindungi tubuh dari berbagai kuman atau trauma, sehingga diperlukan perawatan 
yang adekuat untuk mempertahankan fungsinya. Kulit juga menunjukkan kondisi fisik seseorang dengan adanya warna kulit yang berubah, suhu, kelembaban, ketebalan, tekstur, dan turgor. Untuk menjaga kesehatan kulit dengan mandi sehari minimal 2 kali.

b. Perawatan Kaki dan Kuku

Kebersihan kaki dan kuku merupakan salah satu aspek penting mempertahankan perawatan diri karena bakteri dapat masuk ke tubuh melalui kuku. Perwatan kaki dan kuku yang dilakukan adalah dengan memotong kuku dengan tepat sesuai kebutuhan dan tidak menggigit kuku. Untuk perawatan kaki dengan memakai alas kaki yang pas.

Masalah atau gangguan pada kuku antara lain

1) Ingrown Nail yaitu kuku tangan yang tidak tumbuhtumbuh dan dirasakan sakit pada daerah tersebut.

2) Paronychia yaitu radang disekitar kuku.

3) Ram's Horn Nail yaitu gangguan kuku yang ditandai pertumbuhan yang lambat disertai kerusakan dasar kuku atau infeksi.

4) Bau tidak Sedap akibat reaksi mikroorganisme yang menyebabkan bau.

\section{c. Perawatan rambut.}

Rambut merupakan bagian tubuh yang mempunyai fungsi pelindung dan pengatur suhu, Rambut dapat mencerminkan kondisi kesehatan seseorang, Kerontokan rambut, bisa terjadi sebagai dampak dari gizi kurang., stres, perubahan hormonal, penuaan dan infeksi. Kebersihan rambut yang tidak terjaga menyebabkan ketombe dan bisa menjadi sarang kutu. Perawatan rambut yang bisa dilakukan adalah dengan keramas menggunakan shampo dalam seminggu 1-2 kali atau tergantung kondisi klien. Menggunakan sisir besar pada rambut keriting dan bergigi tumpul.

\section{d. Perawatan gigi dan mulut}


Berbagai bakteri atau mikroorganisme dapat masuk lewat gigi dan mulut untuk itu sangat penting menjaga kebersihan gigi dan mulut. Beberapa organ. yang terdapat dalam rongga mulut yaitu orofaring, kelenjar parotid, submandibula, sublingual, lidah, tonsil dan ovula. Perawatan gigi dan mulut dilakukan dengan cara membersihkan gigi menggunakan sikat gigi berbulu halus dan banyak serta pasta gigi, dilakukan minimal 2 kali dalam sehari yaitu sesudah sarapan pagi dan pada malam hari menjelang tidur.

\section{Praktik Pemenuhan kebutuhan perawatn diri}

\section{a. Mencuci Rambut pasien atau keramas di tempat tidur}

Persiapan Alat

- Sarung tangan disposable dalam kom

- Handuk

- Perlak

- Baskom berisi air hangat

- Shampoo

- Kasa dan kapas dalam kom

- Sisir

- Bengkok

- Gayung

- Ember atau bak mandi

- Apron atau celemek

Prosedur Kerja

- Memberitahu pasien dan menjelaskan tujuan kepada pasien

- Memakai apron kemudian mencuci tangan

- Memakai sarung tangan

- Tutup tirai, pintu atau pasang sampiran (jika di bangsal umum)

- Atur posisi pasien setengah duduk atau tidur

- Setelah posisi diatur lalu letakkan perlak di bawah kepala pasien dan perlak diarahkan ke bawah dengan digulung 
bagian tepi menuju tempat penampungan (ember kosong atau baskom)

- Letakkan baskom di bawah tempat tidur atau tepat di bawah kepala pasien

- Tutup telinga dengan kapas

- Tutup dada dengan handuk sampai leher

- Sisir rambut

- Lakukan pencucian dengan air hangat

- Berikan shampoo ke seluruh permukaan kulit kepala dan rambut sampai dilakukan pemijatan

- Bilas dengan air hangat sampai bersih

- Setelah selesai keringkan rambut dan disisir

- Cuci tangan setelah prosedur dilakukan dan bereskan alat

- Melakukan follow up kepada pasien dan menilai keadaan setelah dilakukan tindakan

b. Memandikan pasien ditempat tidur

Persiapan alat dan bahan

- Sarung tangan disposable dalam kom

- Satu stel pakaian bersih

- 2 buah baskom

- 2 buah waslap

- Apron atau celemek

- buah selimut mandi

- buah handuk mandi

- Sabun mandi dalam tempatnya

- Bedak

- Lotion dan kapas

- Tempat pakaian kotor

- Perlak dan pengalasnya

- Pispot

- Botol berisi air cebok 
- Ember berisi air hangat

Prosedur Kerja

- Memberitahu pasien dan tujuan tindakan dilakukan

- Menutup pintu, jendela

- Memakai apron kemudian mencuci tangan

- Memakai sarung tangan disposable

- Mengganti selimut ibu dengan selimut mandi

- Memberitahu pasien membuka pakaian atas

- Meletakkan handuk di bawah kepala pasien

- Menanyakan pasien mau pakai sabun atau tidak

- Membersihkan muka pasien dari yang terjauh mulai kening memutar mata, pipi, dan leher serta dibilas sampai bersih dan dikeringkan dengan handuk kecil

- Mencuci lengan dengan mengangkat lengan dan meletakkan handuk di atas dada melebarkan ke samping, meletakkan tangan diatas handuk, memulai lebih dahulu lengan yang terjauh. Membasahi, menyabun, membilas dan mengeringkan

- Membersihkan daerah dada dan perut :

$\checkmark$ Membantu klien membuka pakaian bawah dan menurunkan selimut mandi sampai bagian bawah

$\checkmark$ Meletakkan handuk di sisi badan klien dan mengangkat tangan klien

$\checkmark$ Membasahi dada dan perut serta ketiak lalu menyabuni, membilas dan mengeringkan dengan handuk

$\checkmark$ Memasang kembali kain penutup

- Membersihkan punggung dan bokong :

$\checkmark$ Memiringkan klien kesamping dengan posisi kaki ditekuk (sims) dan membelakangi petugas

$\checkmark$ Memasang handuk dibawah punggung sampai bokong 
$\checkmark$ Membersihkan punggung sampai bokong, menyabuni, membilas dan mengeringkan

$\checkmark$ Memberikan bedak

$\checkmark$ Menelentangkan klien dan memasang baju atas

- Membersihkan kaki :

$\checkmark$ Mengeluarkan kaki yang terjauh dari bawah kain penutup

$\checkmark$ Menekuk lutut dan meletakkan handuk dibawahnya

$\checkmark$ Membasahi kaki yang terjauh dahulu, disabuni dan mengeringkan

- Membersihkan daerah lipatan paha dan genetalia :

$\checkmark$ Membentangkan handuk dibawah bokong dan membuka pakaian dibawah perut

$\checkmark$ Menanyakan pada klien apa bisa melakukan sendiri

$\checkmark$ Bila tidak, membasahi daerah lipatan paha, genetalia menyabuni, membilas dan mengeringkan

$\checkmark$ Memasang pakaian bawah klien

- Memberitahu pasien tindakan selesai dilakukan

- Cuci tangan

- Memperhatikan keadaan pasien setelah dilakukan tindakan.

\section{c. Vulva Hygiene}

Persiapan alat

- Bak instrumen steril berisi: sarung tangan steril, pinset anatomi

- Kapas DTT dalam kom

- Air DTT dalam kom

- Bengkok

- Baskom berisi larutan klorin 0,5\%

- Phanthoom vagina

Prosedur Kerja 
- Menjaga privasi pasien dengan menutup tirai, pintu, sampiran

- Memberitahu pasien dan tujuan tindakan dilakukan

- Cuci tangan

- Mendekatkan alat-alat

- Memposisikan pasien dalam keadaan dorsal recumbent, alas bantal dipasang

- Gurita pasien dibuka, pot dipasang (bila pasien merasa ingin berkemih), cawat/softek di angkat, diperhatikan keadaan lochea (banyaknya, warna, bau) lalu diletakkan di bengkok

- Mengatur selimut intan / segitiga

- Memakai sarung tangan

- Cara membersihkan vulva

$\checkmark$ Celupkan kapas DTT ke air DTT dengan menggunakan pinset

$\checkmark$ Tangan kiri membuka vulva, tangan kanan memegang pinset untuk menjepit kapas DTT lalu membersihkan labia mayora terjauh (labia mayora kiri) lalu sebelah kanan, kemudian labia minora terjauh (labia minora kiri) dilanjutkan sebelah kanan kemudian ke vestibulum dan perineum.

$\checkmark$ Satu kapas DTT digunakan hanya satu kali usap, cara mengusapkannya dari depan ke belakang.

$\checkmark$ Lakukan hingga bersih

- Alat habis pakai dibuang dalam bengkok

- Dekontaminasi alat bekas pakai

- Cuci tangan

- Memperhatikan keadaan pasien setelah dilakukan tindakan

\section{i. Kebutuhan eleminasi}

Kebutuhan eleminasi meliputi eleminasi urine dan alvi. 


\section{Eleminasi Urine}

Merupakan proses pengeluaran urine atau air kencing dari kandung kemih yang telah penuh melalui uretra.

Sistem organ tubuh yang berperan dalam eleminasi urine.

Proses pengeluaran ini sangat bergantung pada fungsi-fungsi organ eleminasi seperti ginjal, ureter, kandung kemih atau bladder dan uretra. Ginjal memindahkan air dari darah dalam bentuk urine kemudian masuk ke ureter lalu mengalir ke bladder. Dalam bladder urine ditampung sampai mencapai batas tetentu atau sampai timbul keinginan berkemih, yang kemudian dikeluarkan melalui uretra.

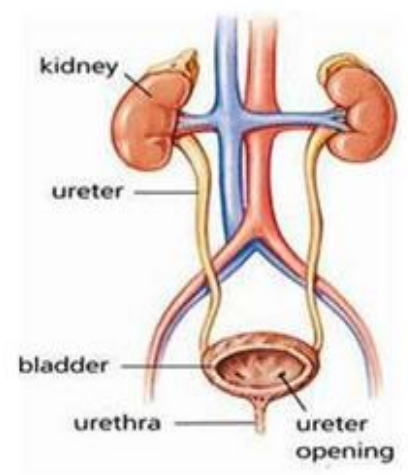

Gb. 5.17 yang berperan dalam eleminasi urine. Sumber :https://azkurs.org/sistem-perkemihan.html

Rata-rata jumlah urine pada orang dewasa dalam sehari adalah 1,2 - 1,5 liter atau $50 \mathrm{ml} / \mathrm{jam}$. Kandungan dalam urin yaitu $95 \%$ air dan $5 \%$ elektrolitdan zat organik. Jumlah urine yang keluar tergantung dari jumlah cairan yang masuk, adanya penyakit metabolik misalnya penyakit diabetes mellitus, glomelurus nephritis. Selain itu juga dipengaruhi penggunaan obat-obatan diuritik.

Fisiologi berkemih 
Urine masuk kandung kemih $\rightarrow$ Terjadi peregangan serat otot dinding kandung kemih $\rightarrow$ Impuls berjalan melalui serabut aferen Menuju pars lumbalis medula spnalis dan transmisikan ke korteks serebri $\rightarrow$ Miksi dikontrol saraf aferen menuju kandung kemih, impuls berjalan ke saraf parasimpatis sakralis menyebabkan otot dinding kandung kemih berkontraksi $\rightarrow$ Sfingter berkontraksi $\rightarrow$ Timbul rangsangan ingin Buang Air Kecil (BAK) $\rightarrow$ Pengeluaran urine : kontraksi otot dinding abdomen dan diafragma, peningkatan tekanan kandung kemih yang sebelumnya terisi $170-230 \mathrm{ml}$.

Indikator urine normal

Berdasarkan pola buang air kecil normal yaitu biasanya orang buang air kecil setelah bangun tidur, setelah bekerja dan makan. Seseorang yang berkemih tergantung pada jumlah asupan cairan . Berdasarkan frekuensi normalnya seseorang BAK dalam sehari berkisar 5 kali. Sedangkan Ciri-ciri dari urine normal yaitu kuning jernih, bau khas amoniak, berat jenis plasma 1.015-1,020.

Ada beberapa macam masalah buang air kecil yaitu :

a. Retensi urine yaitu keadaan seseoarng tidak bisa buang air kecil sehingga urine menumpuk dalam kandung kemih. Penyebab distensi bladder adalah urine yang terdapat dalam bladder melebihi $400 \mathrm{ml}$. Normalnya adalah 250 - $400 \mathrm{ml}$. Kondisi ini bisa disebabkan oleh hipertropi prostat, pembedahan, otot destrusor lemah dan lain-lain.

b. Tidak bisa menahan kencing / Inkontinensia Urine

Bila seseorang mengalami ketidak mampuan otot spinter eksternal sementara atau menetap untuk mengontrol pengeluaran urine.

\section{Eliminasi Fekal}

Eliminasi bowel/fekal/Buang Air Besar (BAB) atau disebut juga defekasi merupakan proses normal tubuh yang penting bagi kesehatan untuk mengeluarkan sampah dari tubuh. Sampah yang dikeluarkan ini disebut feces atau stool. Fungsi usus tergantung pada 
keseimbangan berapa faktor, pola dan kebiasaan eleminasi. Eleminasi bowel merupakan salah satu bentuk aktivitas yang harus dilakukan oleh manusia Seseorang dapat melakukan buang air besar sangatlah bersifat individual ada yang satu kali atau lebih dalam satu hari, bahkan ada yang mengalami gangguan yaitu hanya 3-4 kali dalam satu minggu atau beberapa kali dalam sehari, perubahan eleminasi fekal dapat menyebabkan masalah gastroinstestinal dan sistem tubuh lain, hal ini apa bila dibiarkan dapat menjadi masalah seperti konstipasi, fecal imfaction, hemoraid dan lain- lain.

Proses eleminasi fekal

Beberapa faktor yang berpengaruh pada eleminasi fekal
a. Usia
b. Asupan makanan
c. Cairan yang masuk
d. Aktivitas
e. Stres
f. Kebiasaan
g. Posisi
h. Nyeri
i. Prosedur diagnosis
j. Kehamilan
k. Obat-obatan

\section{Masalah gangguan eleminasi fekal}

a. Obstipasi atau konstipasi

Merupakan keadaan susah buang air besar yang ditandai dengan keluarnya feses yang lama dank eras.

b. Kembung

Merupakan keadaan penuh udara dalam perut karena pengumpulan gas secara berebihan dalam lambung atau usus.

c. Hemorroid

Merupakan keadaan terjadinya pelebaran vena didaerah anus sebagai akibat peningkatan tekanan didaerah anus yang dapat 
disebabkan karena konstipasi, peregangan saat defekasi dan lainlain.

d. Diare

Merupakan keadaan seing buang air besar dan fesesnya dalam bentuk cair. Diare sering disertai dengan kejang usus, mual dan muntah.

e. Incontinensia bowel

Pengeluaran feses yang tidak disadari akibat kerusakan sphinter anus.

3. Praktikum pemasangan kateter untuk membantu kebutuhan eleminasi urine

a. Pemasangan kateter sementara

Persiapan alat dan bahan

- Baki

- Bak intrumen steril berisi : Kateter nelaton sesuai ukuran, pinset anatomi, sarung tangan 1 pasang, kasa

- Kapas DTT dalam kom.

- Air DTT dalam kom.

- Vaseline/gel

- Perlak dan alasnya.

- Bengkok.

- Selimut mandi

- Larutan klorin 0,5 \%

Persiapan pasien

- Penjelasan prosedur.

- Mengatur posisi berbaring.

Prosedur Kerja

- Mendekatkan alat-alat

- Tutu tirai / pintu ruangan

- Mencuci tangan

- Memakai sarung tangan.

- Pasang selimut intan / segitiga 
- Melakukan vulva hygiene

- Mengambil kateter ujungnya diberi vaselin $3-7 \mathrm{~cm}$.

- Membuka labia mayora dengan telunjuk dan ibu jari tangan kiri sampai terlihat meatus uretra, sedangkan tangan kanan memasukkan ujung kateter perlahan kedalam uretra sampai urine keluar, sambil pasien dianjurkan tarik nafas panjang.

- Menampung urine kedalam bengkok atau botol steril bila diperlukan untuk pemeriksaan.

- Bila urine sudah keluar semua secara tuntas, anjurkan pasien menarik nafas panjang, kateter dicabut perlahanlahan lalu dimasukkan ke larutan klorin.

- Melepas sarung tangan dan memasukkan ke dalam larutan klorin.

- Memasang pakaian bawah, mengambil perlak dan pengalas, menarik selimut mandi.

- Membereskan alat.

- Mencuci tangan.

- Mendokumentasikan hasil pelaksanaan.

\section{b. Pemasangan Dower kateter}

Persiapan alat dan bahan

- Baki dengan alas.

- Bak instrument steril berisi: Folley kateter ukuran $16-$ 18 , pinset anatomi, sarung tangan 1 pasang, kassa steril

- Kapas DTT dalam tempatnya

- Air DTT

- Vaselin / gel / pelumas

- Perlak dan alasnya

- Bengkok 2

- larutan klorin 0,5\%

- Plester 
- Gunting plester

- Urin bag

- Spuit 10 cc

- Aquadest

- Selimut mandi

- Korentang + tempatnya

- Handuk cuci tangan

Persiapan Pasien

- Memberitahu dan menjelaskan pada pasien mengenai prosedur yang dilakukan

- Mendekatkan peralatan

- Memasang sampiran

- Mencuci tangan

- Menanggalkan pakaian bagian bawah

- Memasang selimut mandi, perlak dan alas bokong

Cara kerja

- Membuka kateter dan letakkan di dalam bak instrumen

- Membuka urin bag dan menggantungkan di tempat tidur pasien

- Menuangkan vaselin / gel pada kassa steril

- Menyiapkan pasien posisi dorsal recumbent

- Meletakkan bengkok diantara tungkai pasien

- Mencuci tangan dan memakai sarung tangan

- Melakukan vulva hygine

- Mengambil kateter kemudian kemudian ujungnya diberi vaselin $3-7 \mathrm{~cm}$

- Memasukkan kateter perlahan - lahan ke dalam uretra

- Menampung urin ke dalam bengkok atau botol steril bila diperlukan untuk pemeriksaan 
- Bila urin sudah keluar semua, masukkan aquades 10 15 cc (sesuai ukuran kateter) dihubungkan dengan pipa penyambung pada urine bag

- Fiksasi kateter, dengan menggunakan plester pada paha klien

- Mengikat urin bag pada sisi tempat tidur

- Melepas sarung tangan

- Memasang pakaian bawah, mengambil perlak dan pengalas

- Menarik selimut dan mengambil selimut mandi

- Membereskan alat

- Mencuci tangan

Pelepasan /Aff Dower Kateter

- Memberi tahu pasien

- Mendekatkan alat

- Memasang sampiran

- Mencuci tangan

- Membuka plester

- Memakai sarung tangan

- Mengeluarkan isi balon kateter dengan spuit

- Menarik kateter dan anjurkan pasien untuk menarik nafas panjang kemudian letakkan kateter pada bengkok

- Membereskan peralatan dan dekontaminasi

- Melepaskan sarung tangan kemudian mencuci tangan

c. Membatu pasien BAK dan BAB ditempat tidur

Persiapan alat

- Alat / perlak

- Pispot

- Air bersih

- Tisu

- Sampiran apabila tempat pasien di bangsal umum 
- Sarung tangan

- Bel

- Botol berisi air bersih

- Selimut

- Bengkok

\section{Persiapan pasien}

- Pasien di beritahu.

- Pintu / gorden / sampiran di tutup

\section{Cara kerja}

- Cuci tangan dan gunakan sarung tangan

- Pasang sampiran kalau di bangsal umum

- Bantu menurunkan pakaian bawah pasien

- Pasang pengalas di bawah gluteal

- Tempatkan pispot di antara pengalas tepat di bawah gluteal dengan posisi bagian lubang pispot tepat di bawah rectum

- Setelah pispot tepat di bawah glutea, tanyakan pasien apakah sudah nyaman atau belum. Kalau belum atur sesuai dengan kebutuhan.

- Anjurkan pasien untuk buang air besar pada pispot yang telah disediakan

- Bel di dekatkan pada pasien

- Setelah selesai bantu pasien untuk membersihkan anus dan daerah sekitarnya. Kemudian keringkan dengan tisu.

- Pasien di rapikan dan alat - alat dibersihkan

- Catat tanggal dan jam defekasi serta karakteristiknya

- Cuci tangan

\section{Kesimpulan}

1. Pengaturan keseimbangan cairan terjadi melalui mekanisme rasa haus yang dikontrol oleh sistem endokrin (hormonal), yakni 
antdiuritik hormone $\mathrm{ADH}$, sistem aldosterone, prostaglandin, dan glukokortikoid.

2. Kebutuhan oksigen digunakan manusia untuk kelangsungan metabolism sel tubuh bagi individu dan untuk mempertahankan hidupnya. Proses pemenuhan oksigenasi melalui ventilasi, difusi dan transportasi

3. Kebutuhan zat nutrient meliputi karbohidrat, lemak, protein, mineral, vitamin dan air. Masalah kebutuhan nutrisi kekurangan dan kelebihan nutrisi, obesita, mal nutrisi, diabetes mellitus, hipertensi, penyakit jantung coroner, kanker anoreksia nervosa

4. Kebutuhan istirahat berarti menyegarkan diri atau diam setelah melakukan kerja keras. Tidur ada dua jenis Non REM dan REM. Gangguan tidur ada insomnia, parasomia, hipersomia, narkolepsi, apnea saat tidur dan enuresa.

5. Prinsip mekanika tubuh yaitu gravitasi, keseimbangan dan berat. Ada beberapa pengaturan posisi yaitu supinasi, pronasi, fowler, sim, trendelenberg, knee- chest, lithotomi, dan dorsal recumbent.

6. Kebutuhan perawatan diri meliputi perawatan diri pada kulit, kaki dan kuku, rambut dan perawatan gigi mulut.

7. Rata-rata jumlah urine pada orang dewasa dalam sehari adalah 1,2 - 1,5 liter atau 50ml/jam. Ciri-ciri dari urine normal yaitu kuning jernih, bau khas amoniak, berat jenis plasma 1.015-1,020.

8. Eleminasi alvi bersifat individual ada yang satu kali atau lebih dalam satu hari dipengaruhi usia, asupan makanan, cairan yang masuk, aktivitas, stres, kebiasaan, posisi, nyeri, prosedur diagnosis, kehamilan dan bat-obatan.

\section{Latihan Soal}

1. Kebutuhan cairan orang dewasa dalam 24 jam adalah...........
a. $1600-1800 \mathrm{ml}$
b. $2000-2500 \mathrm{ml}$
c. $2200-2700 \mathrm{ml}$ 

d. $2400-2600 \mathrm{ml}$
e. $2600-2800 \mathrm{ml}$

2. Kehilangan cairan sebesar $5-10 \%$ dari berat badan atau sekitar 2-4 liter kondisi pasien masuk kategori
a. Normal
b. Dehidrasi ringan
c. Dehidrasi sedang
d. Dehidrasi berat
e. Dehidrasi sangat berat

3. Pola pernafasan normal untuk bayi baru lahir adalah
a. $30-60 \mathrm{x} / \mathrm{menit}$
b. $20-30 \mathrm{x} /$ menit
c. $18-26 \mathrm{x} / \mathrm{menit}$
d. $12-20 x /$ menit
e. $16-25 \mathrm{x} /$ menit

4. Faktor perilaku yang mempengaruhi fungsi pernafasan, adalah
a. Emosi
b. Bayi prematur
c. Iansia
d. Suhu
e. Kondisi sakit

5. Berapakah Pemberian oksigen dengan masker adalah
a. 5-8 liter/menit
b. 4-6 liter/menit
c. 1-6 liter/menit
d. 1-3 liter/menit
e. 1-2 liter/menit

6. Pemasukan energi dibutuhkan tubuh yang berasal dari lemak sebesar
a. $45 \%$
b. $40 \%$
c. $35 \%$
d. $20 \%$ 

e. $15 \%$

7. Vitamin yang larut dalam air adalah
a. $A, D, E, K$
b. $A, B, C, K$
c. $\mathrm{B}, \mathrm{C}, \mathrm{K}$
d. $B, C$
e. $D, E$

8. Mineral yang berfungsi untuk membantu memelihara keseimbangan cairan dan asam basa adalah
a. Kalsium
b. Magnesium
c. Sodium
d. Zinc
e. Zat besi

9. Yang termasuk karakteristik istirahat adalah

a. Bebas dari gannguan ketidaknyamanan

b. Merasa sendiri

c. Kurang mengetahui yang terjadi

d. Mengetahui apa yang dibutuhhkan

e. Merasa bahwa segala sesuatu belum teratasi

10. Tahap tidur dimana otak masih cenderung aktif dan metabolism meningkat hingga $20 \%$ adalah............
a. REM
b. REM tahap I
c. REM tahap I
d. NREM tahap I
e. NREM tahap II

11. Gangguan tidur gelombang kantuk yang tidak tertahankan muncul secara tiba-tiba pada siang hari disebut....
a. Insomnia
b. Hipersomnia
c. Apnea tidur
d. Narcolepsi 

e. Enuresis

12. Faktor yang mempengaruhi kebutuhan tidur, Kecuali
a. Penyakit
b. Nutrisi
c. Obat-obatan
d. Latihan dan kelelahan
e. Stress fisik

13. Faktor yang mempengaruhi mekanika tubuh, kecuali
a. Status kesehatan
b. Lingkungan
c. Pengetahuan
d. Gaya hidup
e. Nutrisi

14. Pasien yang mau dilakukan pemeriksaan genetalia pada proses persalinan dan pemasangan kontrasepsi IUD maka posisinya adalah
a. Fowler
b. Supinasi
c. Trensdelenburg
d. Litotomi
e. Knee Chest

15. Posisi untuk membantu reposisi letak sungsang dalam kehamilan adalah
a. Fowler
b. Supinasi
c. Trensdelenburg
d. Litotomi
e. Knee Chest

16. Jika seorang ibu bersalin tidak bisa kencing secara spontan maka sikap bidan adalah
a. Memberikan pispot
b. Membantu BAK dikamar mandi
c. Memberikan obat untuk bisa kencing 

d. Menunggu pasien sampai bisa kencing sendiri
e. Memasang kateter

17. Faktor yang mempengaruhi eleminasi alvi adalah
a. Genetik
b. Lingkungan
c. Diet
d. Kondisi fisiologis
e. Pemeriksaan fisik

18. Menumpuknya gas pada lumen intestinal, dinding usus meregang dan distended, merasa penuh, nyeri dan kram
a. Konstipasi
b. Flatulen
c. Hemoroid
d. Incontinensia
e. Impaction

19. Tujuan memandikan pasien adalah... Kecuali

a. Menjaga kebersihan tubuh

b. Memperlancar peredaran darah

c. Menghilangkan bau tidak sedap

d. Mengobati infeksi

e. Membuat pasien rileks

20. Pada pasien yang dilakukan jahitan pada perineum setelah melahirkan maka dilakukan
a. Vulva hygiene
b. Kompres betadin
c. Pemberian antibiotik
d. Mandi seperti biasa
e. Melakukan douching

\section{Daftar Pustaka}


Baston, Helen. Hall, Jennifer. And Einion, Alyson Henley. 2013. Praktik dasar (midwifery Essential) aluh Bahasa Sari Isneini. Volume 1. Jakarta: EGC

Hidayat, A. Aziz Alimul dan Uliyah, M. 2011. Buku Saku Prosedur Ketrampilan Dasar Praktik Klinik. Surabaya: Health Books Publishing Kasiati., Rosmalawati, Ni Wayan Dwi. 2016. Kebutuhan Dasar Manusia. Jakarta : Pusdik SDM

Pratiwi, A. 2019. Buku Ajar Ketrampilan Dasar Kebidanan. Jakarta: Salemba Medika.

Perry, Potter. 2009. Fundalmental of Nursing (fundamental keperawatan). Edisi 7. Translator. dr. Adrina Federika. Jakarta: Salemba Medika

Sutanto, Andina Vita. Fitiana. Yuni. 2017. Kebutuhan Dasar Manusia Teori dan aplikasi dalam Praktik Keperawatan profesional

Yuni, Natalia E Dan Oktami, Rika S. 2014. Ketrampilan Dasar Praktik Klinik Kebidanan . Yogyakarta: Nuha Medika.

https://owlcation.com/stem/Respiratory-Physiology https://healthengine.com.au/info/gastrointestinal-system https://azkurs.org/sistem-perkemihan.html 


\section{BAB VI \\ PEMBERIAN OBAT DALAM PRAKTIK KEBIDANAN}

\section{Tujuan pembelajaran:}

Mahasiswa mampu menguasai teori pemberian obat dan mampu memberikan obat-obatan dalam praktik kebidanan.

\section{A. Definisi Obat}

Suatu zat atau bahan yang digunakan untuk menetapkan diagnosa, mencegah, mengurangkan, menghilangkan, menyembuhkan penyakit/gejala penyakit, luka dan kelainan badania dan rohania pada manusia atau hewan, memperelok badan dan bagian badan manusia.

\section{B. Bentuk Obat}

Ada beberapa bentuk sediaan obat yaitu

1. Padat

Bentuk obat padat berupa seperti tablet, kapsul, pil, kaplet, tablet salut.

2. Cair

Bentuk obat cair meliputi suspensi, sirup, emulsi, elixir, dan solutio.

3. Gas

Bentuk obat gas biasa digunakan dengan bantuan alat yaitu salah satunya nebulizer.

\section{Penggolongan Obat}

Obat digolongkan menurut jenis obat, mekanisme kerja obat, tempat lokasi pemakaian obat, efek yang ditimbulkan dari obat tersebut dan asal obat atau cara pembuatannya.

1. Penggolongan obat menurut jenis

a. Obat bebas adalah obat yang dapat dibeli tanpa resep dokter dan dijual bebas dipasaran. Tanda obat bebas lingkaran berwarna hijau dengan tepi garis warna hitam 
Contohnya : tablet parasetamol, multivitamin dan lain-lain.

b. Obat bebas terbatas yaitu kelompok obat yang dalam jumlah tertentu aman dikomsumsi namun dapat menimbulkan efek yang berbahaya jika terlalu banyak. Tanda obat bebas terbatas yaitu lingkaran biru tepi garis warna hitam pbat ini juga mempunyai peringatan pada kemasasnya senagai berikut: awas obat keras bacalah aturan, memakainya ditelan, atau obat ini untuk bagian luar badan dan lain-lain. Contoh obat : obat flu, antimo CTM, dan lain-lain.

c. Obat wajib apotek yaitu obat keras yang dapat diserahkan oleh apoteker pengelola apotek tanpa resep dokter. Tujuan obat ini untuk meningkatkan kemampuan masyarakat dalam menolong dirinya sehingga tercipta budaya pengobatan sendiri yang tepat, aman dan rasional. Tanda obat ini . Contoh : rar K Yine, salbutamol, antacid dan lain-lain.

d. Obat keras yaitu obat yang berbahaya, pemakaiannya harus dibawah pengawasan dokter dan obat ini hanya dapat diperoleh diapotek, puskesmas, dan fasilitas pelayanan kesehatan lain. Tanda obat ini lingkaran merah tepi hitam ditengah ada hurup $\mathrm{K}$. Con $\mathrm{K}$ antibiotik (amoxicylin), obat jantung, hipertensi dan lain-lain.

e. Psikotropika dan narkotika. Psikotropika yaitu obat yang secara alamiah atau buatan untuk memberikan pengaruh secara selektif pada system syaraf pusat dan menyebabkan perubahan pada aktifitas mental dan perilaku contohnya diazepam, penobarbital amfetamin dan lain-lain. Sedangkan narkotika obat yang berasal dari tanaman atau bukan tanaman baik sintetis maupun semi sintetis yang dapat menyebabkan perubahan kesadaran diri mulai penurunan sampai hilanngnya kesadaran, mengurangi sampai menghilangkan rasa nyeri dan dapat menimbulkan 
ketergantungan contohnya ganja, heroin, morfin, codein, opium dan lain-lain. Simbolnya lingkaran merah ditengahnya terdapat tanda palang merah

\section{Penggolongan obat menurut mekanisme kerja obat}

a. Obat yang bekerja pada penyebab penyakit, misalnya penyakit yang disebabkan bakteri atau mikroba. Contoh: antibiotik.

b. Obat yang bekerja untuk mencegah kondisi patologis dari penyakit. Contoh: vaksin ( vaksin BCG, Campak, polio dan lain-lain) dan serum

c. Obat yang bekerja untuk menghilangkan simtomatik/gejala, seperti meredahkan nyeri, contoh: analgesik. Menurunkan panas, contoh: antipiretik. Mengatasi alergi, contoh : antihistamin. Untuk mengurangi radang contoh : anti inflamasi. Meredahkan batuk contoh (anti tusive). Mengatasi mual dan muntah contoh : anti emetik dan lain-lain.

d. Obat yang bekerja menambah atau mengganti fungsifungsi zat yang kurang. Contoh: vitamin dan hormon.

e. Pemberian placebo yaitu pemberian obat yang tidak mengandung zat aktif, khususnya pada pasien normal yang menganggap dirinya dalam keadaan sakit. Contoh: aqua proinjeksi dan tablet placebo.

\section{Penggolongan obat menurut tempat lokasi pemakai obat}

a. Obat dalam adalah obat-obatan yang dikonsumsi peroral (melalui mulut). Contoh: tablet antibiotik, paracetamol dan lain-lain.

b. Obat luar adalah obat -obatan yang digunakan secara topical/tubuh bagian luar. Contoh Sulfur, salep dan lainlain.

4. Penggolongan obat menurut efek yang ditimbulkan dari obat 
a. Sistemik yaitu obat atau zat yang masuk kedalam system peredaran darah

b. Lokal yaitu obat atau zat yang hanya berefek /menyebar/mempengaruhi bagian tertentu tempat obat tersebut berada. Seperti pada hidung, mata, kulit, dan lainlain.

\section{Penggolongan obat menurut asal obat atau cara pembuatannya}

a. Alamiah yaitu obat yang berasal dari alam (tumbuhan, hewan dan mineral) seperti jamur (antibiotik, kina (kinin) digitalis (glikosida jantung) dari hewan: Placenta, otak yang menghasilkan serum, kolagen.

b. Sintetik yaitu cara pemuatan obat dengan melakukan reaksikimia, contohnya minyak gandapura dihasilkan dari methanol dan asam salisilat.

\section{Persiapan pemberian obat}

Sebelum memberikan obat kepada pasien, harus memperhatikan prinsip 8 benar agar tidak terjadi kesalahan dalam pemberian obat.

\section{Benar pasien}

Sebelum obat diberikan, identitas pasien harus diperiksa dengan teliti oleh perawat untuk mencegah kesalahan pemberian obat pada pasien yang berbeda.

\section{Benar obat}

Semua obat mempunyai nama dagang dan nama generik. Sebelum perawat memberi obat kepada pasien, label pada botol atau kemasannya harus diperiksa sebanyak tiga kali. Pertama pada saat membaca permintaan obat dan botolnya diambil dari tempat obat, kedua label botol disesuaikan dengan obat yang diminta, ketiga saat dikembalikan ke tempat obat. apabila labelnya tidak dapat dibaca, obat tidak boleh digunakan dan harus dikembalikan ke bagian farmasi untuk segera dicek.

\section{Benar dosis}


Jumlah dosis obat harus diperhatikan berapa gram atau mili gram dalam setiap pemberian.

\section{Benar waktu}

Waktu pemberian obat harus diperhatikan obat diminum sesudah makan atau sebelum makan, jam berapa obat diberikan atau setiap berapa jam sekali. Tablet fe tidak boleh diberikan bersamaan dengan minum susu karena menghambat penyerapan obat. Obat-obatan yang mempunyai efek bisa menyebabkan iritasi lambung harus diberikan setelah makan.

\section{Benar rute}

Obat yang diberikan kepada pasien bisa diberikan dalam beberapa rute sesuai dengan kebutuhan dan kondisi pasien tergantung efek yang diinginkan. Rute yang diberikan bisa melalui peroral, sublingual, parenteral, topikal, rektal, inhalasi.

\section{Benar informasi}

Berikan penjelasan tentang tindakan yang akan dilakukan, pada pemberian beri penjelasan obat yang diberikan, cara kerja, fungsi dan efek samping yang mungkin timbul.

\section{Benar respon}

Pastikan obat yang diberikan menghasilkan respon yang sesuai dengan yang diharapkan dari obat tersebut.

\section{Benar dokumentasi}

Setelah memberikan obat kepada pasien, melakukan dokumentasi dengan benar obat apa yang diberikan, dosisnya berapa, pemberiannya melalui rute apa dan jam berapa diberikan serta siapa yang memberikan.Apabila pasien tidak bersedia diberikan obat harus dicatat alasan menolak pemberian obat.

\section{E. Perhitungan Dosis}

Dosis obat adalah jumlah atau ukuran yang diharapakan dapat menghasilkan efek terapi pada fungsi tubuh yang mengalami gangguan. 


\section{Cara menghitung dosis obat}

a. Rumus Young Untuk usia 1-8 tahun kebawah

$$
\mathrm{Da}=\frac{\mathrm{n} \times \mathrm{Dd}}{\mathrm{n}+12}
$$

Contoh

Dosis lazim obat paracetamol pada orang dewasa adalah 1500 $\mathrm{mg} /$ hari untuk menutunkan panas tubuh. Berapa dosis obat yang diberikan pada anak berusia 6 tahun? jawab : $\quad \mathrm{Da}=\underline{6 \times 1500 \mathrm{mg}}=500 \mathrm{mg} /$ hari

$$
6+12
$$

b. Rumus Dilling : untuk anak lebih dari 8 tahun

$\mathrm{Da}=\mathrm{n} \times \mathrm{Dd}$ 20

Contoh :

Dosis lazim obat antalgin pada orang dewasa adalah $1500 \mathrm{mg} / \mathrm{hari}$ untuk mengatasi rasa nyeri. Berapa dosis obat ini untuk anak berusia 10 tahun?

$\mathrm{Da}: \underline{10 \times 1500}=750 \mathrm{mg} /$ hari 20

\section{c. Rumus Gaubius}

Berupa pecahan yang dikalikan dengan dosis dewasa

0-1 tahun $=1 / 12 \times$ dosis dewasa

$1-2$ tahun $=1 / 8 \times$ dosis dewasa

2-3 tahun $=1 / 6 \times$ dosis dewasa

3-4 tahun $=1 / 4 \times$ dosis dewasa

4-7 tahun $=1 / 3 \times$ dosis dewasa

7-14 tahun $=1 / 2 \times$ dosis dewasa

14-20 tahun $=2 / 3 \times$ dosis dewasa

21-60 tahun $=$ dosis dewasa

\section{F. Penggunaan unit Dosis obat}

Menurut fungsinya dosis dapat dikelompokkan sebagai berikut: 
1. Dosis awal/Loading Dose yaitu dosis awal yang dibutuhkan guna tercapainya konsentrasi obat yang diinginkan di dalam darah dan kemudian dilanjutkan dosis perawatan.

2. Dosis pencegahan yaitu jumlah yang dibutuhkan untuk melindungi agar pasien tidak terkena penyakit.

3. Dosis terapi yaitu dosis digunakan untuk terapi pasien terkena penyakit.

4. Dosis lazim yaitu dosis yang secara umum digunakan untuk terapi.

5. Dosis maksima yaitu yang dapat digunakan untuk pengobatan penyakit, yang bila dosis maksimal dilampaui akan menimbulkan efek yang tidak diinginkan.

6. Dosis letaal yaitu dosis yang melebihi dosis terapi dan mengakibatkan efek yang tidak diinginkan dapat menyebabkan kematian.

\section{G. Faktor yang mempengaruhi dosis obat}

1. Faktor obat

Sifat fisika yaitu dari kelarutan obat

Sifat kimia dari obat misalnya asam, basa, garam, ester dan toksisitas

2. Faktor cara penggunaan obat oral, parenteral, lokal dan lainlain

3. Faktor Penderita

- Umur anak, dewasa, geriatrik

- BB Normal, obesitas

- Ras metabolisme obat

- Sensivitas individu

Da dosis anak

n usia anak

Dd : Dosis dewasa

\section{H. Reaksi Obat}




\section{Faktor yang mempengaruhi reaksi obat meliputi:}

1. Absorpsi obat

Suatu proses pergerakan obat dari sumber kedalam tubuh melalui aliran darah, kecuali jenis topikal. Absorbsi obat dipengaruhi oleh aliran darah, rasa nyeri, stres, kelaparan, makanan dan $\mathrm{PH}$.

2. Distribusi obat kedalam tubuh

Setelah obat diabsorbsi, kemudian obat didistribusikan kedalam darah melalui vaskuler dan system limfatis menuju sel dan masuk kedalam jaringan tertentu. Proses ini dapat dipengaruhi oleh keseimbangan cairan, elektrolit dan keadaan patologis.

3. Metabolisme obat

Setelah melalui sirkulasi, obat akan mengalami proses metabolism. Obat akan ke sirkulasi kedalam jaringan, lalu berinteraksi dengan sel dan melakukan suatu perubahan zat kimia hingga menjadi lebih aktif. Obat yang tidak bereaksi akan dieksresikan.

4. Ekskresi sisa

Setelah obat mengalami metabolisme atau pemecahan, akan terdapat zat sisa yang tidak dapat dipakai. Sisa zat ini tidak akan bereaksi kemudian keluar melalui ginjal dalam bentuk urine, dari intestinal dalam bentuk feses dan dari paru-paru dalam bentuk udara.

\section{Mengenali bahaya obat}

1. Penggunaan obat jangka panjang, sangat berbahaya bagi tubuh, bahaya yang ditimbulkan diantaranya adalah:

2. Kerusakan organ jantung

3. Penggunaan obat antibiotik yang terlalu lama, dapat mengakibatkan pengeroposan tulang

Reaksi alergi kemungkinan bisa terjadi, terutama obat antibiotik

1. Terlalu sering mengkonsumsi antibiotik, dapat mengakibatkan resistensi obat tersebut, artinya obat tersebut sudah tidak mampu menyembuhkan penyakit yang dialami. 
2. Kerusakan ginjal kemungkinan bisa terjadi, karena terlalu sering mengkonsumsi obat.

3. Keracunan obat

4. Kematian

5. Pencernaan terganggu, misalnya diare, nyeri pada perut, mual dan iritasi usus besar.

\section{Tanda-tanda alergi obat}

Alergi obat adalah reaksi berlebihan dari sistem kekebalan tubuh yang bisa membahayakan tubuh bagi yang mengkonsumsinya. Sebagian besar obat memiliki gejala yang ringan hingga berat apabila tidak segera ditangani. Apabila saudara mengetahui bahwa obat tersebut terjadi alergi, maka sesegera mungkin penggunaan obat dihentikan. Berikut ini adalah tanda dan gejala seseorang mengalami alergi obat:

1. Gatal-gatal pada kulit

2. Batuk-batuk

3. Demam

4. Sesak nafas

5. Mata berair dan gatal

6. Pembengkakan area wajah, bahkan seluruh tubuh

Apabila terjadi reaksi alergi yang berkelanjutan, maka hal ini dapat mengakibatkan anafilaksis, dimana kondisi tersebut dapat mengakibatkan kegagalan fungsi sistem tubuh, dan diperlukan penangan medis secara cepat.

\section{Mengenali dampak efek samping dan efek terapi obat}

Efek samping obat :

1. Ketergantungan terhadap obat itu sendiri

2. Ketakutan yang berlebihan

3. Emosi yang tidak terkendali

4. Kesulitan tidur

5. Mengalami kebingungan

6. Berhalusinasi 
7. Perubahan kebiasaan tidur

8. Pola makan yang berubah

9. Nafsu makan menurun

\section{Plebotomi, venapunktur dan terapi IV}

Plebotomi merupakan teknik pengambilan spesimen darah untuk pengujian laboratorium. Darah dikumpulkan dengan beberapa metode, termasuk pungsi arteri, kapiler dan pungsi vena (venipuncture).

Prosedur plebotomi

1. Persiapkan tabung dan peralatan yang sesuai dengan prosedur dan sediakan juga tabung tambahan

2. Cuci tangan dan gunakan sarung tangan

3. Posisikan lengan pasien sedikit menekuk dalam poosisi ke bawah. Jangan sampai darah menyentuh stopper pucturing jarum. Jangan biarkan lengan pasien hiperekstensi. Minta pasien untuk mengepalkan tangan. Pasang tourniquet 3-4 inci di atas fossa antecubiti, palpasi daerah tusukankearah vertical dan horizontal untuk mencari pembuluh darah darah besar dan untuk menentukan kedalaman, arah, serta ukuran, Vena median cubiti merupakan pilihan pertama yang diikuti vena chepalica. Vena basalika harus dihindari jika memungkinkan. Lepaskan tourniquet dan minta pasien membuka kepalan tangannya.

4. Bersihkan situs tusukan dengan isosopril alkohol $70 \%$ dalam lingkaran konsentris bergerak keluar dan biarkan kering

5. Rakit peralatan sambil menunggu alkohol mongering, pasang jarum multisample pada pemegangnya.

6. Masukkan tabung kedalam dudukan tabung sampai tanda menujukkan tabung berada dalam dudukan.

7. Ulangi pemasangan tourniquet, jangan menyentuh situs tusukan dengan jari yang tidak steril. Mintalah pasien untuk mengepalkan tangannya kembali. Pasien harus diinstruksikan untuk tidak mengepal-membuka kepalan berulang-ulang, 
tetapi terus mengepal hal ini untuk mencegah hemokonsentrasi.

8. Lepaskan tutup jarum plastic dan periksa kemungkinan jarum cacat misalnya jarumnya cacat atau bergerigi.

9. Regangkan kulit dengan ibu jari sampai 2 inci dibawah situs.

10. Pegang jarum yang telah dirakit pada pemegang tabung menggunakan tangan dominan dengan ibu jari dibagian atas dekat pusat danjari-jari yang lain dibawahnya. Msukkan jarum kepembuluh darah dengan sudut $15-30^{\circ}$ dengan bevel sampai merasa berkurangnya tahanan. Cegah pergerakan jarum lengan yang dapat mengubah posisi jarum ketika memasang tabung. Gunakan ibu jari, dorong tabung ke jarum tabung evakuasi, sambil jari telunjuk dan jari tengah menahan pemegang.

11. Ketika darah telah mengalir kedalam tabung, lepaskan tourniquet dan minta pasien untuk membuka kepalan tangan.

12. Dengan hati-hati, keluarkan tabung ketika darah berhenti mengalir kedalamnya. Dengan lembut, segera bolak-balikkan tabung yang berisi antikoagulan. Masukkan tabung berikutnya (bila dibutuhkan multisampel) dengan urutan yang benar.

13. Tutupi situs tusukan dengan kasa bersih. Tarik jarum keluar dan tekan atau minta pasien untuk menekan.

14. Buang jarum/pemegang yang telah ditutup dengan pengaman kedalam container benda tajam. Beri label pada tabung sebelum meninggalkan pasien dan menverifikasi identitasnya, lengkapi dokumen yang dibutuhkan.

15. Periksa situs tusukan, tempatkan kasa perban diatas libatan untuk memberi tekanan tambahan.

16. Lepaskan sarung tangan dan cuci tangan.

Pengambilan darah vena system terbuka (dengan jarum suntik)

a. Atur posisi pasien, memasang tourniquet dan meminta pasien untuk mengepalkan tangannya. 
b. Pilih vena, buka tahanan tourniquet, minta pasien untuk membuka kepalan tangannya

c. Lepaskan tourniquet, antisespsi daerah yang mau ditusuk

d. Ulangi pemasangan torniquet, menyiapkan jarum suntik

e. Tusuk daerah yang ditentukan dengan mendorong barel jarum suntik.

f. Isap darah dengan menarik plunger, Memasang kasa steril diatas tusukan, tarik jarum dari tusukan

g. Tekan bekas tusukan dengan kasa steril, memasang plester diatas kasa.

h. Buang jarum kedalam container yang telah disediakan.

Pengambilan darah vena dengan wing needle

a. Tempatkan posisi lengan dengan sedikit menekuk pada sendi

b. Pasang tourniquet kira-kira $5 \mathrm{~cm}$ dari sendi tangan

c. Lakukan palpasi pada vena yang akan dlakukan pungsi

d. Desinfeksi daerah pungsi dengan kasa alkohol $70 \%$

e. Tusuk vena yang telah dipilih dengan wing needle, dengan pegang kedua sayap wing needle.

f. Isap darah dengan menarik plunger jarum suntik sambil tangan mempertahankan posisi daerah tusukan.

g. Pasang kasa steril diatas tusukan, tarik jarum wing needle dari tusukan.

h. Tekan bekas tusukan dengan kasa steril, memasang plester diatas kasa.

i. Buang jarum kedalam container yang telah disediakan

\section{Masalah berkaitan dengan plebotomi}

a. Pasien menolak

b. Darah tidak terhisap

c. Vena bergerak -gerak saat ditusuk

d. Volume darah yang terhisap tidak cukup

e. Terjadinya hematom

f. Terisap darah kapiler (berwarna lebih terang) 


\section{Vena punktur atau pungsi vena}

Proses mengumpulkan atau menghisap darah dari pembuluh darah Langkah-langkah vena pungsi

a. Pemeriksaan jenis tes dalam lembar permintaan

b. Pendekatan, indentifikasi pasien

c. Persiapan pasien dengan jelaskan prosedur

d. Verifikasi pembatasan diet dan sensitive terhadap lateks

e. Cuci tangan

f. Posisi, memasang tourniquet 3-4 inci diatas tempat tusukan dan meminta pasien menggenggam.

g. Memilih vena dan melepas tourniquet

h. Membersihkan dan mengeringkan situs tusukan

i. Menyiapkan peralatan dan menggunakan sarung tangan

j. Memasang tourniquet kembali, membuka penutup jarum

k. Melakukan tusukan

I. Mengalirkan darah, melepas tourniquet

m. Memindahkan specimen

n. Menekan tempat tusukan, melakukan prosedur keselamatan

o. Membuang peralatan sesuai prosedur keselamatan

p. Menempel/menulis label pada tabung

q. Membuang bahan terkontaminasi

r. Melepas sarung tangan dan mencuci tangan.

\section{Terapi Intravena}

Terapi intravena adalah memberikan obat melalui pembuluh darah vena, bisa diberikan ke pembuluh darah vena secara langsung (injeksi intravena) atau melalui selang intravena (pada pasien yang terpasang infus, sehingga pemberian obat lewat selang infus)

\section{J. Transfusi Darah}

1. Pengertian 
Transfusi darah adalah proses pemindahan darah dari seseorang (donor) kepada orang lain (resipien)

2. Tujuan transfusi darah

Untuk mengganti darah yang hilang akibat perdarahan, luka bakar, shock dan mempertahankan daya tahan tubuh terhadap infeksi

3. Jenis Transfusi darah

a. Darah lengkap (Whole Blood/WB)

b. Transfusi eritrosit/ Sel darah merah (Packet Red Cell/PRC)

c. Transfusi Trombosit

d. Plasma beku (Fres Frozen plasma/FFP)

\section{Skema transfusi}

a. Golongan darah A bisa mendonorkan darahnya ke golongan darah $A$ dan $A B$ serta menerima donor darah dari golongan $\mathrm{A}$ dan $\mathrm{O}$

b. Golongan darah $B$ bisa mendonorkan darahnya ke golongan darah $B$ dan $A B$ serta menerima donor darah dari golongan $\mathrm{B}$ dan $\mathrm{O}$

c. Golongan darah $O$ bisa mendonorkan darahnya ke golongan darah $A, B$ dan $A B$, tetapi golongan darah $O$ hanya bisa menerima donor dari golongan darah $\mathrm{O}$ saja.

d. Golongan darah $A B$ bisa menerima donor dari golongan darah $A, B, A B$ dan $O$, namun golongan $A b$ hanya bisa mendonorkan darahnya ke golongan darah $A B$ saja. 


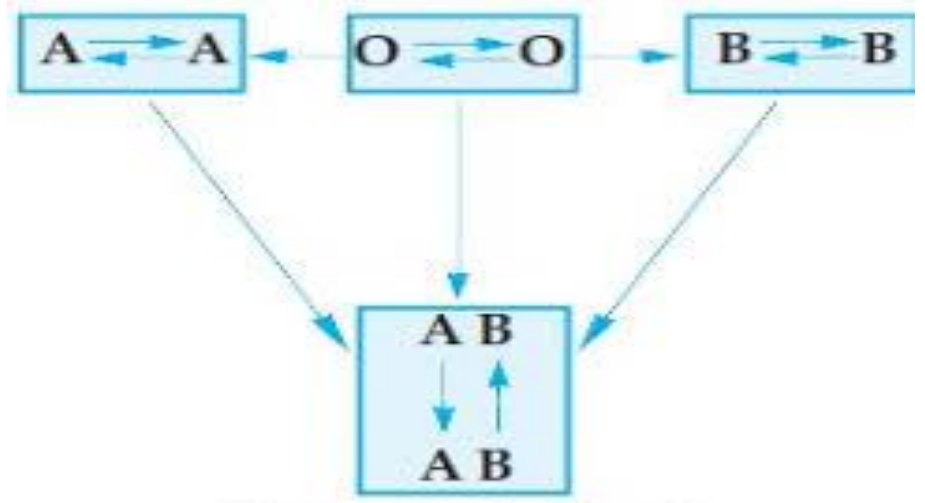

Gb. 6.1 Skema transfusi darah

\section{Efek samping transfusi}

Efek samping akut/segera pada transfusi

a. Reaksi demam disebabkan oleh antibody penerima bereaksi dengan antigen sel darah putih dalam produk darah atau karena sitokin yang terakumulasi pada produk darah selama penyimpanan.

b. Reaksi urtikaria (alergi) terjadi $1 \%$ penerima disebabkan oleh protein plasma asing.

c. Reaksi alergi berat (anafilaksis) terjadi akibat defisiensi IgA yang memiliki anti-lgA.

d. Reaksi Hemolitik akut disebabkan akibat transfusi darah yang tidak cocok pada system $A, B, O$.

e. Kontaminasi bakterika

f. Cedera paru akut terkait transfusi akibat interaksi antigen leukosit pasien dengan antibody donor atau sebaliknya.

g. Oveload volume, Pasien vascular paru dan bayi memi8liki risiko mengalami overload volume terutama selama transfusi cepat.

h. Hipothermi, Infus secara cepat dengan cadangan volume darah yang disimpan berpengaruh terhadap terjadimya hipotermi. Bayi sangat berisiko selama transfuse massif. 
i. Keracunan sitrat, Strat adalah antikoagulan dalam produk darah, biasanya cepat dimetabolisme oleh hati.

j. Efek kalium, Eritrosit mengalami kebocoran kalium secara proporsional sepanjang hidup pada masa penyimpanan. Iradiasi eritrosit akan meningkatkan kebocoran kalium. Secara klinis hyperkalemia dapat terjadi secara signifikan dengan transfusi cepat, volume besar eritrosit yang lebih tua dan pada bayi dan nak-anak.

\section{Efeksamping transfusi tertunda/lambat}

a. Hemolisis tertunda terjadi akibat pasien menghasilkan antibobi terhadap antigen pada eritrosit dari darah transfusi.

b. Aloimunisasi eritrosit (Pembentukan aloantibodi penderita tidak menunjukkan gejala, ditemukan pada saat pengujian pra transfusi, sehingga akan diberikan darah antigen negatif)

c. Transfusi terkait Graft vs Host disease (Ta-GVHD) terjadi ketika limfosit donor berkembang biak dan merusak organ sasaran terutama sumsum tulang, kulit, hati dan saluran pencernaan.

d. Efek Imunodilator (Beberapa penelitian menunjukkan adanya hubungan transfusi darah dan peningkatan risiko infeksi, kekambuhan kanker, hingga saat ini belum terbukti)

e. Akumulasi/timbunan besi (terjadi pada transfuse eritrosi jangka panjang)

\section{Praktik Transfusi Darah}

Persiapan Alat

- Kassa dalam kom.

- Kapas alkohol dalam kom.

- Alkohol $70 \%$ pada tempatnya. 
- Abbocath + Tranfusi set.

- Cairan $\mathrm{NaCl} 0,9 \%$

- Duk + pengalas bersih.

- Sarung tangan disposabel dalam kom.

- Torniquet.

- Standart infuse

- Bengkok

- Plester.

- Gunting Plester

- Larutan klorin 0,5\%

- Darah yang diperlukan (RBC, WBC, dsb)

Persiapan Pasien

- Penjelasan prosedur.

- Mengatur posisi berbaring

Prosedur Kerja

- Mencuci tangan.

- Memakai sarung tangan disposable

- Memasang duk dan pengalas di bawah pasien.

- Memasang transfusi set pada standard (keluarkan udara)

- Melakukan antisepsis daerah yang akan dipasang infuse.

$\checkmark$ Tekan vena sasaran infuse dengan tourniquet atau dengan bantuan orang lain.

$\checkmark$ Posisi mata jarum abbocath menghadap keatas.

- Penyelesaian.

$\checkmark$ Fiksasi jarum abbocath

$\checkmark$ Sambungkan dengan darah yang di butuhkan (sebelum dan sesudah pemberian transfusi darah berikan cairan Nacl 0,9\%)

- Membereskan alat-alat.

- Mencuci tangan.

- Membuat catatan observasi.

Catatan : 
Sebelum darah dimasukkan terlebih dahulu suhu darah, cek warna darah, identitas pasien, jenis golongan darah, dan tanggal kadaluarsa

\section{K. Teknik Pemberian Obat}

Teknik Pemberian Obat dikelompokan dalam beberapa cara pemberian yaitu peroral, parenteral, topical dan inhalasi.

\section{Per Oral}

a. Pengertian

Menyiapkan dan memberikan obat kepada melalui mulut dan selanjutnya ditelan

b. Tujuan pemberian obat per oral

1) Memberikan obat kepada klien melalui mulut Secara tepat dan benar, sesuai dengan program pengobatan.

2) Memudahkan pemberian obat

3) Efek samping yang ditimbulkan mudah diatasi karena reabsorbsi obat lebih lambat

c. Pemberian obat peroral memiliki keuntungan sebagai berikut: pasien merasa nyaman, mudah, pasien tidak kawatir, dan efek yang ditimbulkan bisa lokal dan sistemik.

d. Kelemahan obat yang diberikan secara peroral yaitu efek yang ditimbulkan lambat, Pada pasien dengan kondisi mual muntah, semi koma dan mempunyai gangguan menelan tidak bisa diberikan secara peroral.

e. Indikasi pemberian obat per oral yaitu pasien tidak ada kelainan saluran pencernaan dan membutuhkan absorbsi obat secara tepat.

f. Kontraindikasi dari pemberian obat secara peroral adalah pasien yang mempunyai kelainan sistem pencernaan misalnya kanker mulut, kesulitan menelan dan lain-lain. 


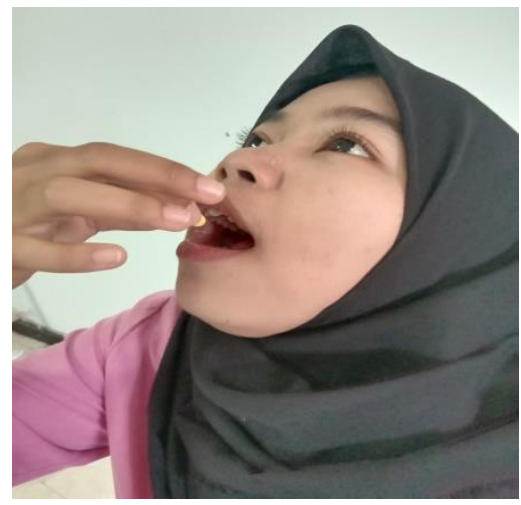

Gb. 6.2 Pemberian obat peroral

g. Cara melakukan pemberian obat peroral

1) Persiapan alat

- Daftar buku obat / formulir pencatatan

- Baki / cawan obat

- Tongue Spatel (untuk pemberian obat sublingual)

- Segelas air dan sedotan

- Obat dalam tempatnya

2) Persiapan Pasien

- Kaji terhadap setiap kontraindikasi untuk memberikan obat oral, termasuk kesulitan menelan

- Keakuratan dan kelengkapan kartu obat dengan advis dokter

1) Prosedur Kerja

- Cuci tangan

- Atur cangkir obat didalam baki/cawan obat

- Baca obat dengan prinsip tepat obat, tepat pasien, tepat posisi, tepat waktu, dan tepat tempat/rute pemberian

- Membagikan obat dengan cara : 
$\checkmark$ Apabila memberikan obat berbentuk tablet atau kapsul dari botol, maka tuangkan jumlah yang dibutuhkan ke dalam tutup botol dan pindahkan ke tempat obat (cawan). Jangan sentuh obat dengan tangan.

Untuk obat berupa kapsul jangan dilepaskan pembungkusnya (kecuali pasien mengalami gangguan menelan, tablet dihaluskan dalam bentuk serbuk)

$\checkmark$ Bila obat bentuk cair, buka penutupnya dan letakkan pada posisi terbalik:

Pegang botol dengan label ditelapak tangan ketika menuangkan

Pegangan cangkir obat atau sendok obat setinggi mata dan isi sampai batas yang diinginkan

Skala harus sama dengan cairan pada dasar miniskus

- Cek kembali buku obat dengan obat yang sudah dibagikan di cawan obat

- Bawalah obat ke pasien pada waktu yang tepat

- Minta pasien menyebutkan namanya sambil membandingkan nama yang tertera pada cawan obat

- Jelaskan tujuan obat dan efek pada pasien

- Atur posisi pasien sesuai dengan kenyamanan pasien

- Bantu pasien minum obat

- Mencuci tangan

- Mendokumentasikan

- Membereskan alat-alat

- Kembali 30 menit untuk mengevaluasi respon pasien

\section{Parenteral}

Pemberian obat parenteral Adalah memberikan obat melalui parenteral yaitu memasukkan obat ke dalam jaringan tubuh dengan 
mengggunakan spuit atau semprit dan jarum suntik steril. Macamnya : Intracutan, subcutan, intravena dan intramuscular

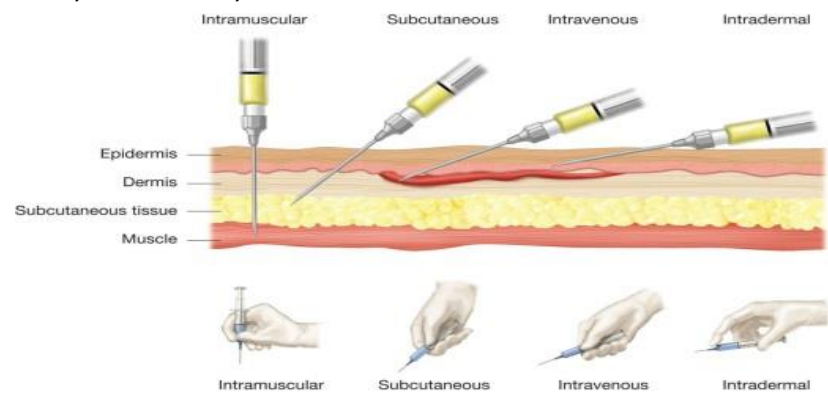

Gb. 6.3 Posisi jarum saat injeksi parenteral

Sumber:http://keterampilandasarkesehatan.blogspot.com/2018/08 /lengkap-metode-pemberian-obat-injeksi.html

\section{a. Injeksi secara intrakutan}

1) Pengertian

Intra kutan adalah cara memberikan obat dengan dengan memasukkan obat kedalam kulit.

2) Tujuan :

- Mendapatkan efek kerja obat secara lokal

- Melakukan test terhadap reaksi alergi obat seperti obat antibiotik dan melakukan Manthox test (tuberkulin test)

3) Lokasi Penyuntikan

Lokasi dipilih pada daerah yang mudah diamati seperti; yang tidak banyak mengendung pigmen, berkeratin tipis, tidak berambut. Daerah yang sesuai kriteria adalah: ventral lengan bawah, daerah klavikula, permukaan media paha.

4) Cara melakukan pemberian obat intrakutan 


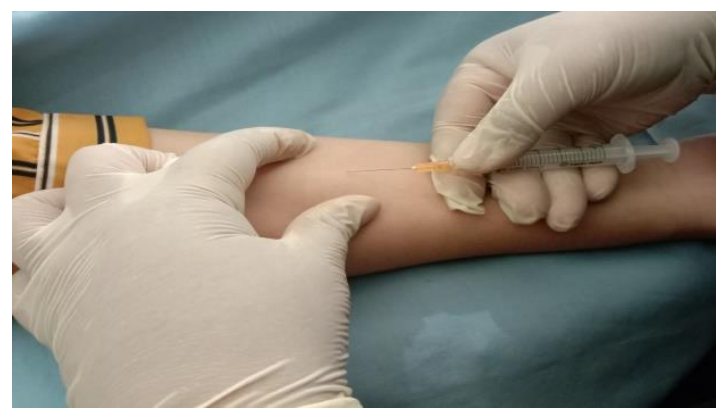

Gb.6.4 Injeksi intracutan

Persiapan Alat :

- Spuit sesuai jumlah obat yang diberikan

- Jarum pengganti sesuai kebutuhan

- Kapas antiseptik pada tempatnya

- Ampul atau vial obat

- Buku Injeksi / obat

- Sarung tangan disposible

- Pengalas + perlak

- Bengkok

- Bak Injeksi

Prosedur Kerja

- Mencuci tangan sebelum melakukan tindakan

- Mengecek peralatan dan pastikan benar obat, dosis, waktu dan cara pemberian

- Memakai sarung tangan

- Menyiapkan obat dari vial atau ampul, melarutkan obat jika obat berupa bubuk dengan cairan pelarut (aquadest). Selanjutnya, ambil 0,5 cc dan encerkan lagi sampai \pm 1 cc. Kemudian ganti jarum, memastikan tidak ada udara dalam spuit, lalu meletakkan kedalam bak instrumen 
- Memastikan benar pasien dengan mengecek identitas klien dan menyebut nama klien dan menanyakan riwayat alergi obat.

- Menjelaskan tindakan yang akan dilakukan

- Membantu klien untuk mengambil posisi yang nyaman bergantung pada tempat suntikan yang dipilih.

- Memasang pengalas dibawah lengan yang mau diinjeksi

- Memiilih tempat penyuntikan yang tepat yang tidak terdapat luka, lecet dan jaringan parut.

- Meminta klien tidak tegang, rileks dengan bicara pada klien tentang subjek yang menarik.

- Membersihkan tempat suntikan yang dipilih dengan swab kasa antiseptic secara melingkar dari dalam keluar sekitar $5 \mathrm{~cm}$ (2 inci).

- Memegang swab dengan tangan yang ditidak dominan diantara jari 3 dan 4

- Membuka penutup jarum

- Melakukan penyuntikan: Tegangkan daerah yang akan di suntik dengan tangan kiri

- Membaca bassmallah sebelum penyuntikanLakukan penusukkan dengan lubang menghadap ke atas yang sudutnya 15-20 derajat terhadap permukaan kulit

- Menyemprotkan obat hingga terjadi gelembung

- Mencabut jarum dengan cepat sambil meletakkan swab antiseptik tepat dibawah suntikan dan tidak boleh di lakukan massage

- Membantu klien mendapatkan posisi yang nyaman

- Meletakkan jarum kedalam safety box

- Mendekontaminasikan sarung tangan sebelum melepaskan dan mencuci tangan 
- Melakukan dokumentasi

- Mengecek respon pasien 15-30 menit setelah pemberian obat.

\section{b. Injeksi secara subcutan}

1) Pengertian

Injeksi subkutan diberikan lebih dalam daripada injeksi intradermal. Obat dimasukkan diantara kulit dan otot dan akan bereaksi setelah 30 menit

2) Tujuan : injeksi secara subkutan biasanya dilakukan pada pasien DM untuk mengontrol kadar glukosa darah dengan pemberian obat insulin. Serta imunisasi campak pada bayi dan balita.

3) Lokasi penyuntikan.

Dilakukan pada daerah lengan atas, perut, paha dan punggung bagian atas yang memiliki cukup bantalan lemak. Sudut jarum dari permukaan kulit saat melakukan injeksi adalah $45^{\circ} \mathrm{C}$.

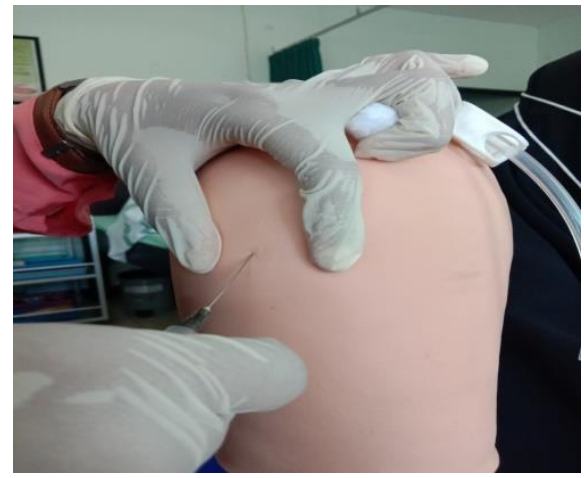

Gb.6.5 Penyuntikan SC di lengan atas

4) Cara melakukan pemberian injeksi subcutan

Persiapan alat

- Spuit tergantung jumlah obat yang diberikan

- Jarum pengganti sesuai kebutuhan

- Kapas alkohol dalam kom/ alcohol swab

- Ampul atau vial obat 
- Buku Injeksi / obat

- Sarung Tangan disposable

- Bengkok

- Bak Injeksi tertutup

- Alcohol $70 \%$

- Baskom berisi larutan klorin 0,5\%

Prosedur Kerja

- Mencuci tangan sebelum melakukan tindakan

- Mengecek peralatan dan pastikan benar obat, dosis, waktu dan cara pemberian

- Menggunakan sarung tangan

- Menyiapkan obat dari vial atau ampul, melarutkan obat jika obat berupa bubuk dengan cairan pelarut (aquadest). Mengambil obat sesuai dengan dosis. Kemudian ganti jarum, Memastikan tidak ada udara dalam spuit lalu meletakkan kedalam bak instrumen

- Memastikan benar pasien dengan mengecek identitas klien dan menyebut nama klien dan menanyakan riwayat alergi obat.

- Menjelaskan tindakan yang akan dilakukan

- Memiilih tempat penyuntikan yang tepat yang tidak terdapat luka, lecet dan jaringan parut.

- Membantu posisi yang nyaman untuk pasien dan bergantung bagian mana yang disuntik. Tempat Suntikan Subkutan lengan/paha depan/daerah abdomen/area scapula dan punggung bagian atas. daerah ventrogluteal dan dorsogluteal bagian atas

- Meminta klien tidak tegang, rileks dengan bicara pada klien tentang subjek yang menarik.

- Membersihkan tempat suntikan yang dipilih dengan swab kasa antiseptik secara melingkar dari dalam keluar sekitar $5 \mathrm{~cm}$ ( 2 inci). 
- Memegang swab dengan tangan yang ditidak dominan diantara jari 3 dan 4

- Membuka penutup jarum

- Memegang spuit di antara ibu jari dan jari telunjuk dari tangan anda yang dominan

Suntikan Subkutan

$\checkmark$ Posisikan tangan non dominan untuk menegangkan daerah yang akan dilakukan suntikan sub kutan

$\checkmark$ Baca bassmalah sebelum penyuntikan

$\checkmark$ Lakukan penusukkan dengan lubang menghadap ke atas, yang sudut 45 derajat dengan permukaan kulit

$\checkmark$ Lakukan aspirasi. Bila tidak ada darah, semprotkan obat perlahan-lahan hingga habis.

- Meletakkan kapas alkohol tepat di bawah suntikan dan mencabut jarum dengan cepat.

- Menekan bekas suntikan dengan kapas alkohol

- Meletakkan jarum kedalam safety box

- Mendekontaminasikan sarung tangan sebelum melepaskan dan mencuci tangan

- Melakukan dokumentasi

- Mengecek respon pasien 15-30 menit setelah pemberian obat.

\section{c. Injeksi secara intramuscular}

1) Pengertian

Pemberian obat dengan cara dimasukkan ke jaringan otot dengan sudut jarum dari permukaan kulit saat melakukan injeksi adalah 90 ${ }^{\circ} \mathrm{C}$.

2) Tujuan mendapatkan reaksi obat lebih cepat oleh karena vaskularitas otot. 
3) Lokasi penyuntikan

Lima tempat injeksi intramuscular yang digunakan adalah: dorsogluteal (pada posisi tengkurap), ventrogluteal pada posisi berbaring, paha ( vastus lateralis), rectus femoris, dan pada lengan (deltoid)

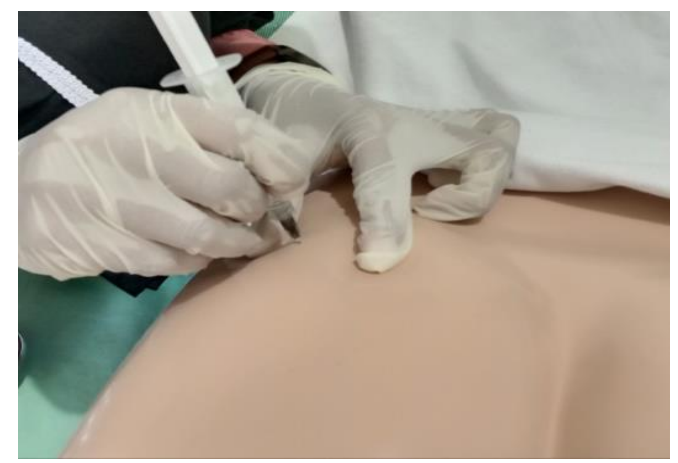

Gb.6.6 Injeksi IM Ventrogluteal

4) Cara melakukan injeksi intramuscular

Persiapan Alat

- Spuit sesuai dengan jumlah obat yang diberikan

- Jarum pengganti sesuai kebutuhan

- Kapas alkohol dalam kom / Alcohol Swab

- Ampul atau vial obat

- Buku Injeksi / obat

- Sarung Tangan Disposable

- Bengkok

- Bak Injeksi tertutup

- Alkohol 70 \% dlm botol

- Baskom berisi larutan 0,5\%

Prosedur kerja

- Mencuci tangan 
- Mengecek peralatan dan pastikan benar obat, dosis, waktu dan cara pemberian

- Menggunakan sarung tangan

- Menyiapkan obat dari vial, melarutkan obat jika obat berupa bubuk dengan cairan pelarut (aquadest). Mengambil obat sesuai dengan dosis. Kemudian ganti jarum, lalu meletakkan kedalam bak instrumen

- Memastikan benar pasien dengan mengecek identitas klien dan menyebut nama klien dan menanyakan riwayat alergi obat.

- Menjelaskan tindakan yang akan dilakukan

- Memiilih tempat penyuntikan yang tepat yang tidak terdapat luka, lecet dan jaringan parut.

- Memastikan pasien dalam posisi yang nyaman dan tergantung lokasi penyuntikan

- Tempat suntikan intramuskular

- Paha (vastus lateralis) - klien berbaring terlentang dengan lutut sedikit fleksi

$\checkmark$ Dorsogluteal - klien tengkurap dengan lutut diputar kearah dalam, atau miring dengan lutut bagian atas dan pinggul fleksi dan diletakkan didepan tungkai bawah

$\checkmark$ Lengan atas (deltoid) - klien duduk atau berbaring mendatar dengan lengan atas refleksi tetapi rileks menyilang abdomen atau diatas abdomen

$\checkmark$ Ventrogluteal - Posisi pasien bisa tengkurap atau tidur miring dengan lutut dan panggul flexi pada bagian yang mau disuntik.

- Meminta klien tidak tegang, rileks dengan bicara pada klien tentang subjek yang menarik

- Mencari tempat yang akan dipilih sebagai tempat suntikan 
- Membersihkan tempat suntikan yang dipilih dengan swab kasa antiseptik secara melingkar dari dalam keluar sekitar $5 \mathrm{~cm}$ (2 inci).

- Memegang swab dengan tangan yang ditidak dominan diantara jari 3 dan 4

- Membuka penutup jarum

- Memegang spuit di antara ibu jari dan jari telunjuk dari tangan anda yang dominan

- Meregangkan kulit dengan tangan yang tidak dominan pada daerah yang akan disuntik

- Membaca basmallah sebelum penyuntikan

- Menyuntikan jarum dengan cepat pada sudut 90 derajat

- Melakukan aspirasi dengan menarik plunger spuit $\checkmark$ Jika terlihat darah di dalam spuit, tarik kembali jarum, buang spuit, dan ulangi persiapan obat.

$\checkmark$ Jika tidak terlihat darah, suntikan obat dengan perlahan.

- Mencabut dengan cepat jarum suntik dan meletakkan kapas alkohol pada bekas suntikan.

- Menekan bekas suntikan

- Membantu klien mendapatkan posisi yang nyaman

- Meletakkan jarum kedalam safety box

- Mendekontaminasikan sarung tangan sebelum melepaskan dan mencuci tangan

- Melakukan dokumentasi

- Mengecek respon pasien 15-30 menit setelah pemberian obat.

\section{d. Injeksi secara intravena}

1) Pengertian

Pemberian obat intravena adalah pemberian obat dengan cara memasukkan obat kedalam pembuluh darah vena menggunakan 
spuit. Pemberian obat secara intravena merupakan pemberian obat yang sangat berbahaya. obat tersebut bereaksi dengan cepat karena obat masuk kedalam sirkulasi klien secara langsung

2) Tujuan diberikan obat secara intravena menghendaki efek yang cepat karena langsung ke peredaran darah dan obat diberikan mempunyai jumlah yang besar serta tidak bisa diberikan secara peroral karena mengalami gangguan menelan/ pencernaan.

3) Keuntungan dan kerugian

Keuntungan dari pemberian obat secara intravena yaitu cepat reaksinya, dianjurkan untuk kondisi gawat darurat dan obat yang diberikan dalam jumlah besar,sedangkan kerugiannya beakibat fatal jika salah memberikan obat, jika ada alergi cepat reaksinya dan injeksi secara intravena tidak bisa dilakukan pada semua obat.

4) Lokasi penyuntikan secara intravena bisa dilakukan pada daerah pembuluh darah pada tangan maupun kaki. Pembuluh darah yang ada pada tangan yaitu vena basalika, dosal metacarpal cephalika dan lain-lain.

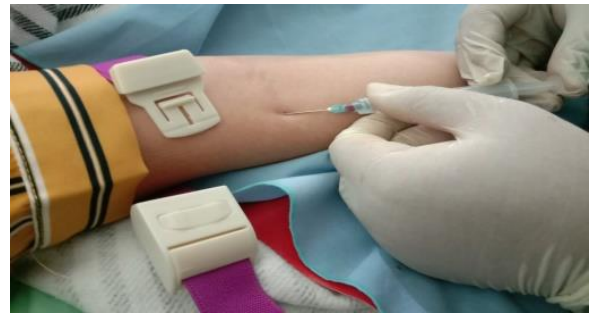

Gb. 6.7 Injeksi Intravena

5) Praktik pemberian injeksi intravena

Persiapan alat

- Spuit tergantung jumlah obat yang diberikan

- Jarum pengganti sesuai kebutuhan

- Kapas alkohol dlm kom / alkohol swab

- Ampul atau vial obat 
- Buku Injeksi / obat

- Sarung tangan disposable

- Pengalas + perlak

- Tourniquet

- Bengkok

- Bak Injeksi tertutup

- Alkohol $70 \%$ dalam botol

- Baskom berisi larutan klorin 0,5\%

Prosedur Kerja

- Mencuci tangan sebelum melakukan tindakan

- Mengecek peralatan dan pastikan benar obat, dosis, waktu dan cara pemberian

- Menggunakan sarung tangan

- Menyiapkan obat dari vial atau ampul, melarutkan obat jika obat berupa bubuk dengan cairan pelarut (aquadest). Mengambil obat sesuai dengan dosis. Kemudian ganti jarum no 25 , memastikan tidak ada udara dalam spuit, lalu meletakkan kedalam bak instrumen

- Memastikan benar pasien dengan mengecek identitas klien dan menyebut nama klien dan menanyakan riwayat alergi obat.

- Menjelaskan tindakan yang akan dilakukan

- Memiilih tempat penyuntikan yang tepat yang tidak terdapat luka, lecet dan jaringan parut.

- Memasang pengalas dan perlak dibawah area yang disuntik

- Memastikan pasien dalam posisi yang nyaman

- Meminta klien tidak tegang, rileks dan melemaskan tangannya dengan bicara pada klien tentang subjek yang menarik 
- Mencari tempat yang akan dipilih sebagai tempat suntikan

- Membersihkan tempat suntikan yang dipilih dengan swab kasa antiseptik secara melingkar dari dalam keluar sekitar $5 \mathrm{~cm}$ (2 inci).

- Memegang kapas alkohol/ alkohol swab dengan tangan yang ditidak dominan diantara jari 3 dan 4

- Membuka penutup jarum

- Melakukan penyuntikan:

$\checkmark$ Pasang tourniquet

$\checkmark$ Ambil spuit yang berisi obat

$\checkmark$ Baca bassmallah sebelum penyuntikan

$\checkmark$ Lakukan penusukkan dengan lubang jarum menghadap keatas dengan sudut 15 derajat.

$\checkmark$ Lakukan aspirasi, bila sudah ada darah, lepaskan tourniquet dan langsung masukkan obat secara perlahan sampai habis

- Mencabut dengan cepat jarum suntik dan meletakkan kapas alkohol pada bekas suntikan.

- Menekan bekas suntikan

- Membantu klien mendapatkan posisi yang nyaman

- Meletakkan jarum kedalam safety box

- Mendekontaminasikan sarung tangan sebelum melepaskan dan mencuci tangan

- Melakukan dokumentasi

- Mengecek respon pasien 15-30 menit setelah pemberian obat.

\section{Topikal dan Inhalasi}

Obat yang diberikan melalui rute topikal (pemberian obat ke kulit atau membran mukosa) dapat diterapkan secara eksternal atau 
internal. Obat yang dioleskan secara topikal memiliki efek lokal atau sistemik.

Pemberian obat secara topical/inhalasi adalah sebagai berikut:

a. Pemberian obat pada kulit

Pemberian obat pada kulit merupakan obat yang dioleskan pada permukaan kulit dengan tujuan mendapatkan efek local. Obat yang diberikan pada kulit bisa berbentuk krim, lotion, aerosol dan spray.

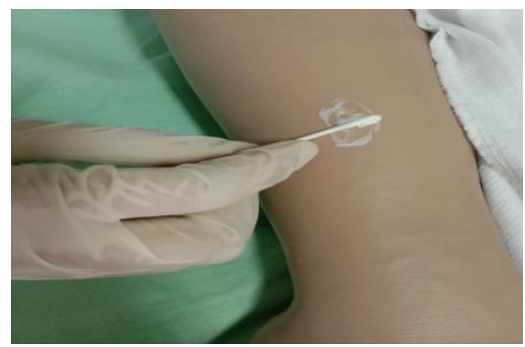

Gb. 6.8 Pemberian obat kulit

Teknik Pemberian obat pada kulit

Alat dan bahan yang disiapkan:

- Obat kulit yang mau diberikan

- Kassa steril

- Sarung tangan steril / sekali pakai

- Balutan (kassa balut) dan plester jika perlu

- Gunting plester

- Perlak \& pengalas

- Bengkok

- Baskom berisi air sabun dan air hangat, waslaf, handuk

- Buku obat

- Cotton bud

Prosedur Kerja

- Mengecek instruksi dokter obat yang diberikan, jam pemberian, dosis dan cara pemberian 
- Mencuci tangan sebelum melakukan tindakan

- Menggunakan sarung tangan

- Mendekatkan peralatan

- Menutup sampiran

- Memastikan benar pasien dengan mengecek identitas klien dan menyebut nama klien

- Menjelaskan tindakan yang akan dilakukan

- Mengatur posisi yang nyaman, melepaskan pakaian (pada daerah yang akan diobati) dan pertahankan area yang tidak digunakan agar tetap tertutup

- Memasang pengalas dibawah daerah yang akan dilakukan tindakan

- Menggunakan sarung tangan (jika luka terbuka gunakan sarung tangan steril)

- Membersihkan daerah yang akan diberi obat dengan air hangat (apabila ada bagian kulit mengeras)

- Memberikan obat sesuai dengan indikasi dan cara pemakaian seperti mengoleskan dan mengompres (jika menggunakan salep, maka gunakan secara tipis-tipis dan merata)

- Menutup area yang diobati dengan kasa atau perban jika diperlukan.

- Membereskan peralatan

- Mepaskan sarung tangan,

- Mencuci tangan

- Mendokumentasikan tindakan yang telah dilakukan

\section{b. Memberikan obat mata}

Cara memberikan obat dengan mengoleskan atau meneteskan obat yang berupa salep atau tetes pada kelopak mata/ sakus konjungtiva untuk mendapatkan efek lokal. 


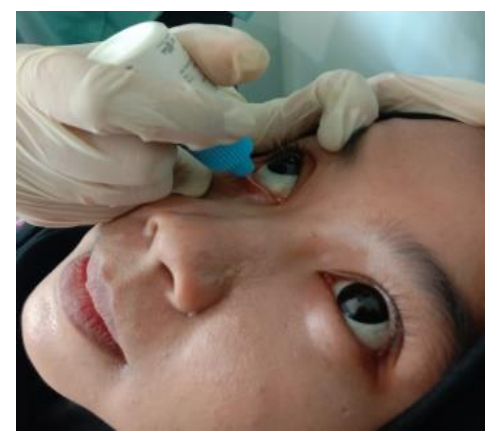

Gb.6.9 Pemberian tetes mata

Cara memberikan obat mata Alat dan bahan yang disiapkan

- Tetes mata/ salep mata

- Tissue / kasa dalam kom

- Kapas DTT dalam kom

- Air DTT dalam kom

- Penutup mata / eye patch (tidak menjadi keharusan)

- Sarung tangan disposable dalam kom

- Air hangat dalam kom

- Bengkok

Prosedur Kerja

- Mengecek instruksi dokter obat yang diberikan, jam pemberian, dosis dan cara pemberian

- Mencuci tangan sebelum melakukan tindakan

- Memastikan benar pasien dengan mengecek identitas klien dan menyebut nama klien

- Menjelaskan prosedur pemberian pada pasien

- Mengambil posisi disebelah kanan pasien dan menganjurkan pasien menengadahkan kepala (hiperekstensi

- Memakai sarung tangan 
- Menggunakan kapas lembab membersihkan kelopak dan bulu mata mulai bagian dalam keluar kantus

- Menggunakan tangan yang tidak dominan (letakkan ibu jari dan telunjuk pada tulang orbita) untuk membuka mata secara perlahan-lahan dengan tisu.

- Menganjurkan pasien melihat keatas

- Memberikan obat mata sesuai bentuk obat:

Obat tetes :

$\checkmark$ Memegang obat tetes mata dengan tangan yang dominan berada didahi pasien $\pm 1-2 \mathrm{~cm}$ diatas sakus konjungtiva

$\checkmark$ Meteskan sejumlah obat kedalam sakus konjungtiva

$\checkmark$ Menganjurkan pasien menutup mata perlahanlahan setelah diberi tetes mata.

Obat salep :

$\checkmark$ Memberikan obat salep pada kelopak mata bawah pasien dianjurkan melihat keatas, tangan petugas memegang aplikator dengan posisi berada atas kelopak mata lalu menekan tube sampai obat keluar, Setelah selesai anjurkan pasien untuk melihat kebawah, secara bergantian dan berikan obat pada kelopak mata bagian atas. Biarkan pasien untuk memejamkan mata dan menggerakkan kelopak mata.

$\checkmark$ Tutup mata dengan kassa bila perlu

- Membereskan peralatan yang telah digunakan

- Melepaskan sarung tangan, cuci tangan

- Mendokumentasikan tindakan yang telah dilakukan

\section{c. Memberikan obat telinga}

Memberikan obat tetes melalui saluran telinga dengan tujuan untuk mengobati infeksi lokal pada telinga atau untuk melunakkan serumen pada telinga sehingga mudah dibersihkan. 


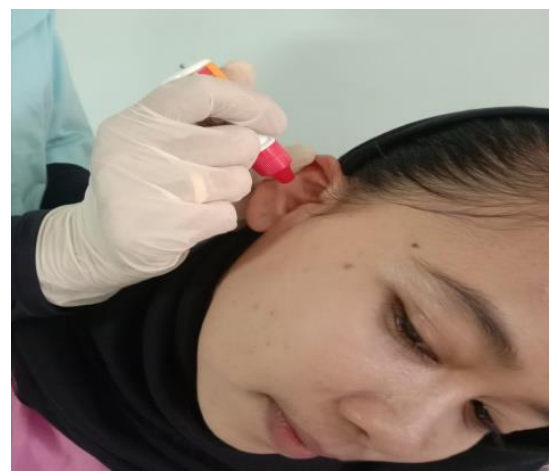

Gb. 6.10 Pemberian tetes telinga

Cara memberikan obat telinga

Alat dan bahan yang disiapkan:

- Tetes telinga

- Tissue/kassa

- Sarung tangan disposable dalam kom

- Bengkok

Prosedur Kerja

- Mengecek instruksi dokter obat yang diberikan, jam pemberian, dosis dan cara pemberian

- Mencuci tangan

- Memeriksa gelang identitas dan tanyakan nama pasien

- Menjelaskan prosedur pemberian pada pasien

- Mengatur posisi pasien dengan kepala menengadah (hiperekstensi) atur posisi pasien dengan kepala miring ke kanan atau ke kiri sesuai dengan daerah yang akan diobati, usahakan agar lubang telingan pasien keatas

- Menggunakan sarung tangan

- Meluruskan lubang telinga dengan menarik daun telinga ke atas / kebelakang pada orang dewasa dan ke bawah pada anak-anak 
- Apabila obat berupa tetes, maka teteskan obat dengan jumlah tetesan sesuai dosisi pada dinding saluran untuk mencegah terhalang oleh gelembung udara

- Mempertahankan posisi kepala \pm 2-3 menit

- Menutup telinga dengan pembalut dan plester kalau perlu

- Membereskan alat yang digunakan

- Melepaskan sarung tangan

- Mondokumentasikan tindakan yang telah dilakukan

\section{d. Pemberian Obat pada hidung}

Pemberian obat pada hidung merupakan obat yang diberikan melalui hidung, biasanya menggunakan obat tetes atau spray.

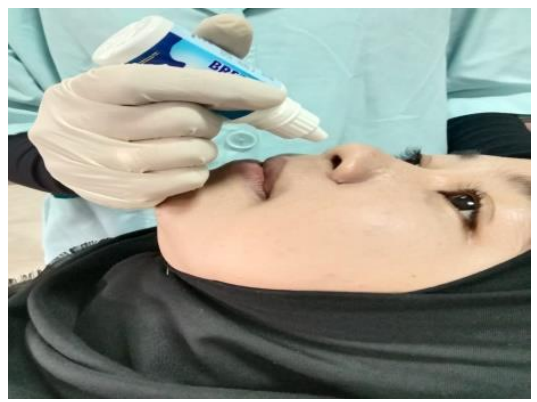

Gb. 6.11 Pemberian tetes Hidung

Teknik memberikan obat hidung

Alat dan bahan yang harus disiapkan

- Tetes hidung

- Spekulum hidung

- Tissue dan kassa

- Lidi Kapas/ Cotton Bud

- Kom berisi air DTT

- Sarung tangan bersih dalam kom

- Bengkok

Prosedur Kerja 
- Mengecek instruksi dokter obat yang diberikan, jam pemberian, dosis dan cara pemberian

- Mencuci tangan sebelum melakukan tindakan

- Meriksa gelang identitas dan tanyakan nama pasien

- Menjelaskan prosedur pemberian pada pasien

- Mengatur posisi pasien :

$\checkmark$ Duduk dikursi dengan kepala menengadah kebelakang

$\checkmark$ Berbaring dengan kepala ekstensi pada tepi tempat tidur

$\checkmark$ Berbaring dengan bantal dibawah bahu dan kepala tengadah ke belakang

- Menggunakan sarung tangan

- Membersihkan hidung dengan menggunakan lidi kapas/ kassa dengan menggunakan air DTT

- Memasang spekulum hidung

- Pada setiap lubang hidung ditetesi obat sesuai dengan dosis.

- Menganjurkan pasien selama 5 menit untuk menengadah kebelakang

- Membersihkan dengan menggunakan tissu, jika terdapat keluaran cairan/ kotoran dari hidung

- Membereskan peralatan

- Melepaskan sarung tanggan dan mencuci tangan

- Mendokumentasikan tindakan yang telah dilakukan

e. Pemberian obat Sublingual

Obat yang diletakkan di sublingual, dibawah lidah

Tujuan

1) Agar efek yang ditimbulkan bisa lebih cepat karena pembuluh darah di bawah lidah merupakan pusat dari sakit

2) memperoleh efek lokal dan sistemik, 
3) Mmperoleh aksi kerja obat yang lebih cepat dibandingkan secara oral dan

4) menghidari kerusakan obat oleh hepar..

Teknik Pemberian obat sublingual

f. Obat yang diletakkan di buccal, antara pipi dan gusi

g. Pemberian obat pervaginam

Pemberian obat yang dimasukan melalui vagina untuk memperoleh efek lokal dan sistemik.

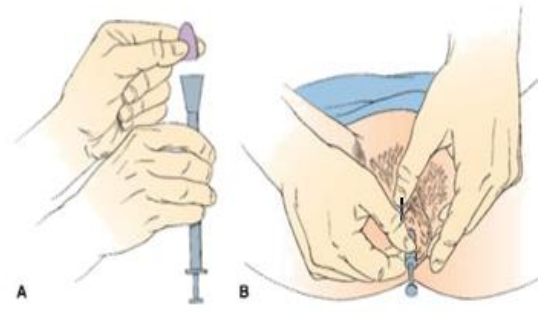

Gb. 6.12 Obat Pervaginam

Sumber:http://xfarmakologi.blogspot.com/2016/09/carapemberian-obat.html

Teknik memberikan obat pervaginam

Persiapan Alat dan bahan

- Obat suppositoria vagina

- Sarung tangan steril dalam bak instrumen

- Tissue

- Jelly untuk pelumas

- Buku pemberian obat

- Bengkok

- Larutan klorin 0,5\%

Prosedur Kerja

- Mengecek instruksi dokter obat yang diberikan, jam pemberian, dosis dan cara pemberian

- Melakukan cuci tangan 
- Menjelaskan prosedur pemberian pada pasien

- Memeriksa identitas pasien dengan membaca gelang ID dan menanyakan nama pasien

- Menjaga privasi pasien dengan menutup gorden atau sampiran

- Menganjurkan pasien tidur dengan posisi dorsal recumbent

- Mempertahankan selimut pada bagian abdomen dan turunkan selimut bagian ekstremitas

- Memakai sarung tangan steril

- Membuka bungkus obat suppositoria vagina dan mengoleskan sejumlah pelumas (jelly) pada ujung obat suppositoria.

- Merenggangkan daerah lipatan labia menggunakan tangan yang tidak dominan.

- Membaca bassmallah dan masukkan obat sepanjang dinding kanal vagina posterior sampai 7,5-10 cm.

- Setelah obat masuk keluarkan jari secara perlahan dan kemudian bersihkan daerah sekitar orifisium dan labia dengan tissue

- Menganjurkan pasien untuk tetap dalam posisi dorsal recumbent selama \pm 10 menit agar obat bereaksi

- Melepaskan sarung tangan dan lakukan dokontaminasi sarung tangan pada larutan klorin 0,5\% dengan posisi terbalik

- Mencuci tangan

- Mendokumentasikan tindakan yang telah dilakukan

h. Pemberian obat perektal/per anus

Pemberian obat via anus merupakan cara memberikan obat dengan memasukkan obat melalui anus atau rektum, dengan tujuan memberikan efek lokal dan sistemik. Tindakan pcngobatan ini disebut pemberian obat suppositoria. 
Memberikan obat secara perektal bertujuan untuk mendapatkan efek lokal misalnya obat pencahar yang berfungsi untuk melunakkan feces sehingga memudahkan untukbuang air besar. Selain itu juga untuk mendapatkan efek sistemik misalnya supaya bronkus berdilatasi maka diberikan aminopilin supositoria.

Obat yang diberikan secara perektal diletakkan pada dinding anus. Pada pasien yang mengalami operasi pada daerah anus tidak bisa diberikan obat perektal

Teknik Pemberian obat per anus

Persiapan alat dan bahan

- Obat suppositoria rektal

- Sarung tangan bersih sekali pakai

- Tissue

- Jelly untuk pelumas

- Buku pemberian obat

- Bengkok

- Larutan klorin 0,5\%

Prosedur Kerja

- Mengecek instruksi dokter obat yang diberikan, jam pemberian, dosis dan cara pemberian

- Melakukan cuci tangan

- Menjelaskan prosedur pemberian pada pasien

- Memeriksa identitas pasien dengan membaca gelang ID dan menanyakan nama pasien

- Menjaga privasi pasien dengan menutup gorden atau sampiran

- Menganjurkan pasien tidur dengan posisi Sim (miring dengan tungkai bagian atas di fleksikan kedepan sedangkan kaki yg lain diluruskan

- Mempertahankan selimut pada bagian abdomen dan ekstremitas dan hanya bagian anal yang terpajan

- Memakai sarung tangan bersih 
- Membuka bungkus obat suppositoria rektal dan oleskan sejumlah pelumas (jelly) pada ujung obat suppositoria. Berikan pelumas (jelly) pada jari telunjuk dari tangan yang dominan.

- Menganjurkan pasien untuk tidak tegang terutama bagian anus

- Merenggangkan daerah glutea menggunakan tangan yang tidak dominan

- Membaca bassmallah dan kemudian memasukkan obat suppositoria pelan-pelan, lewati anus pada orang dewasa sampai dinding rectum $\pm 10 \mathrm{~cm}$ sedangkan pada bayi dan anak $\pm 5 \mathrm{~cm}$.

- Mengeluarkan jari secara perlahan dan membersihkan daerah sekitar anus menggunakan tisu setelah obat masuk.

- Mempertahankan pasien tetap dalam posisi sim sampai obat bereaksi selama \pm 5 menit.

- Mendekontaminasi sarung tangan pada larutan klorin 0,5\% dan melepas dengan posisi terbalik

- Mencuci tangan

- Mendokumentasikan tindakan yang telah dilakukan

\section{Epidural}

Epidural merupakan salah satu bentuk bius lokal yang digunakan pada bagian tubuh tertentu untuk membuatnya mati rasa. Bius epidural bukanlah bius total, jadi ketika epidural dilakukan, pasien tak akan kehilangan kesadaran sepenuhnya. Fungsi utama dari epidural adalah sebagai penawar rasa sakit atau sebagai analgesia.

\section{Ada 2 Jenis Epidural:}

- Epidural biasa yaitu bius yang satu ini akan disuntikkan di bagian punggung ibu bersalin (pada bagian otot punggung) hingga penawar rasa sakit ini mencapai rongga epidural. Kandungan yang ada pada epidural ini biasanya adalah 
fentanyl ataupun morfin. Efeknya tak akan bertahan lama dan akan habis sekitar satu jam hingga dua jam kemudian. Namun setelah itu, pasien akan mendapatkan suntikan berikutnya.

- Kombinasi spinal epidural yaitu dimana obat-obatan bius disuntikkan atau diinjeksikan pada membran yang melapisi tulang belakang hingga mencapai rongga epidural. Setelah itu, sebuah selang atau kateter akan dipasangkan pada jalur tersebut sehingga apabila akan diberikan injeksi lagi, akan lebih mudah prosesnya. Pada epidural kali ini, pasien tetap bisa bebas bergerak meski terpasang selang atau kateter dan ini tidak akan mengganggu proses persalinan. Untuk kombinasi spinal epidural ini akan habis efeknya setelah empat hingga delapan jam kemudian.

\section{Indikasi}

Epidural sifatnya tidak wajib atau tidak harus dilakukan. Ada beberapa pasien yang lebih kuat menahan rasa sakit namun ada juga yang tidak kuat menahan rasa sakit. Biasanya mereka yang lebih kuat menahan rasa sakit akan memilih untuk tidak melakukannya dan menjalani proses kelahiran normal pada umumnya. Namun sebaliknya, pasien bisa menggunakan bius ini apabila dirasa tak bisa menahan sakit ketika melahirkan normal. Epidural bisa diberikan untuk persalinan normal maupun sesar. Apabila pada proses persalinan bukaan sudah mencapai 4 hingga $5 \mathrm{~cm}$, maka epidural tak disarankan karena bayi sebentar lagi akan keluar. Sementara itu, untuk operasi sesar, epidural biasanya dilakukan sebelum proses operasi dijalankan.

\section{Catatan penting bagi yang akan melakukan epidural!}

Beberapa kondisi di bawah ini tak disarankan melakukan epidural, seperti :

1. Apabila pasien mengalami pendarahan

2. Apabila pasien sedang memiliki tekanan darah yang rendah 
3. Adanya infeksi pada area punggung

4. Apabila pasien diberikan pengencer darah

5. Apabila proses persalinan berjalan dengan cepat atau bukaan sudah mencapai 4 hingga $5 \mathrm{~cm}$

6. Apabila tenaga medis tak bisa menemukan letak rongga epidural

\section{Manajemen nyeri non farmakologi}

Ada beberapa cara mengurangi atau mengatasi nyeri secara non faramakologi antara lain :

\section{Aromaterapi}

Efek dari minyak ini bisa diperoleh melalui penggunaan inhalasi menggunakan pembakar minyak atau penyerapan kulit menggunakann pijat. Aromaterapi mendorong pelepasan neurotransmiter, seperti encephalines dan endorphin yang memiliki efek analgesik dan menghasilkan perasaan tenang. Neurotransmitter lain yang dikeluarkan dapat memperbaiki suasana hati. Efek analgesik minyak esensial dalam konteks pendekatan holistik untuk manajemen nyeri kronis, dapat digunakan sebagai tambahan atau alternatif untuk pendekatan medis konvensional. Aplikasi langsung dari minyak esensial pada kulit dapat mengurangi peradangan, memberikan anestesi dan analgesia, mengurangi kejang, dan menciptakan kehangatan atau pendinginan. Minyak atsiri dapat secara positif mempengaruhi suasana hati seseorang, pola tidur, tingkat energi, rasa percaya diri dan kontrol dalam manajemen nyeri

\section{Teknik Distraksi}

Teknik distraksi merupakan teknik yang dilakukan dengan memfokuskan perhatian pasien pada sesuatu selain nyeri. Distraksi diduga dapat menurunkan persepsi nyeri dengan menstimulasi system control desenden, yang mengakibatkan lebih sedikit stimulasi nyeri yang ditransmisikan ke otak. Keefektifan transmisi tergantung 
pada kemampuan pasien untuk menerima dan membangkitkan input sensori selain nyeri.

\section{Kompres hangat}

Kompres hangat merupakan salah satu metode non farmakologi untuk mengurangi nyeri. Kompres hangat dapat memberikan rasa hangat untuk memenuhi kebutuhan rasa nyaman, mengurangi atau membebaskan nyeri, mengurangi atau mencegah spasme otot dan memberikan rasa hangat pada daerah tertentu. Kompres hangat dapat dilakukan dengan menempelkan kantong karet yang diisi air hangat atau handuk yang telah direndam di dalam air hangat, ke bagian tubuh yang nyeri. Sebaiknya diikuti dengan latihan pergerakan atau pemijatan. Dampak fisiologis dari kompres hangat adalah pelunakan jaringan fibrosa, membuat otot tubuh lebih rileks, menurunkan atau menghilangkan rasa nyeri, dan memperlancar aliran darah.

\section{Terapi Musik}

Musik memberikan efek positif terhadap pengurangan rasa sakit. Begitu juga stimulasi gelombang otak. Sebenarnya dalam kondisi tertentu, otak bisa memproduksi zat anestesi alami yang disebut "endorphin". Endorphine biasanya diproduksi secara alami oleh tubuh saat otak dalam kondisi gelombang otak delta yang dalam. Stimulasi gelombang otak pada CD Pain Relief ditujukan untuk membawa otak Anda ke kondisi deep delta sehingga tubuh Anda memproduksi lebih banyak endorphin untuk menghilangkan/mengurangi rasa sakit. Dalam sebuah studi yang menyatakan mendengarkan musik merangsang gelombang alpha otak yang telah ditentukan sebagai stimulator untuk membebaskan endorphin dan menciptakan keadaan relaksasi dan karena musik telah memainkan peran tidak hanya dalam menghilangkan rasa sakit tetapi juga menurunkan tekanan darah, detak jantung, dan tingkat respon fisiologis lainnya 


\section{Masase}

Masase adalah melakukan tekanan tangan pada jaringan lunak, biasanya otot, tendon atau ligamentum, tanpa menyebabkan gerakan atau perubahan posisi sendi untuk meredahkan nyeri, menghasilkan relaksasi dan memperbaiki sirkulasi

\section{Hidroterapi}

Hidroterapi adalah perendaman dalam air merupakan salah satu cara analgesia yang dapat menimbulkan relaksasi otot, meningkatkan vasodilatasi yang dapat menimbulkan peningkatan aliran darah, dan perasaan sejahtera secara umum. Mandi air hangat, pancuran dan kolam bergelombang paling mungkin menimbulkan relaksasi merangsang ujung-ujung saraf yang menimbulkan pembalikan respons sistem saraf simpatik sehingga mengurangi nyeri.

\section{Trancutaneous Electrical Nerve Stimulation (TENS)}

TENS efektivitasnya berkaitan dengan cara kerja TENS yang menstimulasikan produksi endorphin dan ensephalin alami, yang kemampuannya untuk menghambat stimulasi nyeri yang datang.

\section{Homeopati}

Homeopati merupakan terapi nonfarmakologi yang bertujuan untuk memperkuat respons fisiologis tubuh. Homeopati berusaha untuk mengobati penyakit yang diobati. Obat Hemeopati dibuat dari ekstrak tumbuhan dan mineral dan dalam metode ini perlu mempertimbangkan dari semua segi kebutuhan individu

\section{Akupunktur}

Jarum dimasukkan ke kedalaman 2,5-3 cm dan dimanipulasi secara manual atau tegangan $2-3 \mathrm{~Hz}$ arus rendah untuk mencapai analgesia. akupunktur analgesia diduga dimediasi melalui pelepasan endorphin atau pelepasan serotonin dan encephalines, akan tetapi teknik ini memberikan penghilang rasa sakit yang tidak lengkap, tidak terduga dan tidak konsisten

\section{Akupresur}


Akupresur merupakan pengembangan dari teknik akupunktur. Pada prinsipnya tujuan kedua perawatan ini tidak berbed tergantung darijenis keluhan. Keduanya dipakai untuk merangsang titik-titik yang ada di tubuh, menekan hingga masuk ke sistem saraf. Jika dalam penerapan akupunktur harus memakai jarum, maka dengan hanya memakai gerakan dan tekanan jari yaitu jenis tekan putar, tekan titik, dan tekan lurus akupresur dapat dilakukan

\section{Posisi, Postur dan Ambulasi}

Posisi-posisi yang dipilih ibu dalam menghadapi persalinan kala I dan II sangatlah penting. Posisi persalinan, perubahan posisi dan pergerakan yang tepat akan membantu meningkatkan kenyamanan atau menurunkan rasa nyeri, meningkatkan kepuasan akan kebebasan untuk bergerak dan meningkatkan kontrol diri ibu.

\section{Hypno-birthing}

Metode hypno-birthing merupakan salah satu tehnik otohipnosis (selfhypnosis) atau swasugesti alam menghadapi kehamilan dan persiapan melahirkan yang berfungsi membantu wanita hamil melalui masa persalinannya dengan cara alami, lancar, dan nyaman (tanpa rasa sakit) dan untuk kesehatan jiwa dari bayi yang dikandungnya. Gelombang otak alfa-beta tubuh mengeluarkan endorphin. dan menghambat pengeluaran hormon katecolamin (hormon stres) yang menjadi penyebab utama otot-otot mengencang dan mengerut. Pada kondisi stres, tegang dan takut susunan saraf otonom (SSO) sebagai jaringan komunikasi dalam tubuh memberikan perintah pada sistem saraf simpatis untuk memberikan mekanisme pertahanan diri dengan cara fight, flight or freeze (lawan, lari atau membeku) pada tubuh. Pada saat beraksi denyut jantung meningkat semakin kuat dan tubuh berespon secara defensive. Sistem ini sementara menghentikan dan menutup arteriarteri yang mengalir ke organ-organ non essensial untuk pertahanan. Setiap ibu hamil yang memasuki proses persalinan sering dibayang- 
bayangi oleh perasaan takut, cemas, dan kawatir. Jika sejak awal kehamilan ibu telah dilatih untuk selalu tenang dan relaks dengan metode hypnosis, maka ketika proses awal persalinan tiba secara otomatis pikiran ibu yang telah terprogram akan memerintahkan pada tubuh untuk mengeluarkan hormon endorphin (kekuatannya 200 kali lipat dari morphin) hormon ini dapat menetralisir rasa nyeri yang timbul, menciptakan ketenangan dan kedamaian serta dapat membuat ibu mengalami amnesia

\section{Yoga}

Yoga menyediakan relaksasi dengan menggunakan latihan pernapasan dan meditasi dengan gerakan lambat. Hal ini dianggap bahwa hal itu dapat berguna terhadap nyeri muskuloskeletal dalam hal menggunakan gerak peregangan fisik dan meningkatkan kekuatan

\section{Kesimpulan}

1. Ada 3 bentuk obat yaitu padat, cair dan gas. Penggolongan obat berdasarkan jenis, mekanisme kerja, tempat lokasi, efek yang ditimbulkan, asal obat atau cara pembuatannya.

2. Persiapan pemberian obat harus memperhatikan prinsip 8 benar yaitu benar pasien, benar obat, benar dosis, benar waktu, benar rute, benar informasi, benar respon dan benar dokumentasi.

3. Perhitungan dosis obat ada beberapa cara antara lain dengan cara Young, Dilling dan Gaubius.

4. Tanda alergi obat meliputi gatal-gatal pada kulit, batuk-batuk demam, sesak nafas mata berair dan gatal serta pembengkakan area wajah, bahkan seluruh tubuh

5. Transfusi darah bertujuan untuk mengganti darah yang hilang akibat perdarahan, shock, luka bakar dan mempertahankan daya tahan tubuh terhadap infeksi. Jenis transfusi darah lengkap/WB, PRC, tromosit dan plasma beku.

6. Teknik pemberian secara peroral, parenteral, topikal dan inhalasi 
7. Pemberian obat parenteral yaitu memasukkan obat kedalam jaringan tubuh menggunakan spuit. Ada beberapa cara yaitu secara intrakutan, subkutan, intravena dan intramuscular.

8. Pemberian obat topikal diberikan ke kulit atau mukosa untuk mendapatkan efek lokal maupun sistemik. Pemberian obat topikal antara lain pemberian obat pada kulit, mata, telinga, hidung, perektal dan pervaginam.

6. Epidural diberikan untuk mengurangi rasa sakit dengan menyuntikkan obat anasthesi pada bagian punggung ibu bersalin.

7. Manajemen nyeri non farmakologi antara lain dengan aromaterapi, teknik distraksi, kompres hangat, terapi masase, terapi musik, hidroterapi, TENS, homeopati, akupresur, akupunktur dan lain-lain.

\section{Latihan soal}

1. Ibu hamil yang mengalami mual muntah diberikan bidan obat...
a. Analgesik
b. Anti convulsi
c. Anti emetik
d. Anti spasmodik
e. Antibiotik

2. Prinsip 8 benar dalam pemberian obat adalah benar..

a. Pasien, obat, dosis, waktu, rute, informasi, respon, dan situasi

b. Pasien, obat, dosis, waktu, rute, informasi, respon, dan Dokumentasi

c. Pasien, dosis, lokasi, waktu, rute, informasi, respon, dan Dokumentasi

d. Pasien, obat, dosis, waktu, rute, reaksi, lokasi, dan situasi

e. Pasien, obat, dosis, waktu, rute, informasi, reaksi, dan situasi

3. Dosis yang diberikan dalam jumlah yang dibutuhkan untuk melindungi agar pasien tidak terkena penyakit adalah 

a. Dosis awal
b. Dosis maksimum
c. Dosis letal
d. Dosis terapi
e. Dosis Pencegahan

4. Dosis lazim Ciprofloxacin orang dewasa adalah $1500 \mathrm{mg} / \mathrm{hari}$ untuk mengobati infeksi. Berapa dosis obat ini untuk anak berusia 10 tahun dalam sehari ?
a. $250 \mathrm{mg}$
b. 450
c. $500 \mathrm{mg}$
d. $750 \mathrm{mg}$
e. $800 \mathrm{mg}$

5. Yang disebut resipien umum adalah golongan darah
a. A
b. $B$
c. $A B$
d. 0
e. A dan B

6. Yang disebut Donor umum adalah golongan darah
a. A
b. $B$
c. $A B$
d. $O$
e. A dan B

7. Seorang bidan melakukan test antibiotika maka teknik penyuntikan adalah
a. Intra kutan
b. Subcutan
c. Intra Vena
d. Intra Muskuler
e. Sub dermal 
8. Reaksi pada pemberian obat parenteral akan timbul dalam waktu.....
a. 15 menit
b. 10 menit
c. 5-7 Menit
d. 15 detik -5 menit
e. 7-10 detik

9. Pemberian obat insuline dilakukan secara
a. Intrakutan
b. Subkutan
c. Intradermal
d. Intra vena
e. Intra muskular

10. Yang benar mengenai injeksi intramuskular adalah

a. Lokasi pada gluteus maksimus, sudut $90^{\circ}$ dari permukaan kulit

b. Lokasi pada gluteus maksimus, sudut $45^{\circ}$ dari permukaan kulit

c. Lokasi pada ventral lengan bawah, sudut $90^{\circ}$ dari permukaan kulit

d. Lokasi pada ventral lengan bawah, sudut $45^{\circ}$ dari permukaan kulit

e. Lokasi pada permukaan media paha, sudut $90^{\circ}$ dari permukaan kulit

11. Pemberian obat yang paling berbahaya dan menimbulkan reaksi sangat cepat adalah
a. Intra kutan
b. Intra vena
c. Inta murcular
d. Subkutan
e. Sub dermal

12. Tujuan dari pemberian obat mata, kecuali

a. Mengobarti gangguan matas 
b. Menghilangkan iritasi lokal

c. Menguatkan otot lensa mata

d. Mendilatasi pupil

e. Pengukuran refraksi mata

13. Teknik Pemberian secara topikal, kecuali
a. Per oral
b. Rektal
c. Sub lingual
d. Kulit
e. Mata

14. Pernyataan yang benar tentang epidural adalah
a. Merupakan bius total
b. Fungsi utama mempercepat persalinan
c. Epidural biasa efeknya bertahan 1-2 jam
d. Hanya untuk pasien SC
e. Boleh digunakan pada pasien yang mengalami pembukaan 5 $\mathrm{cm}$

15. Manjemen nyeri non farmakologi dengan memberikan tekanan pada jaringan lunak, otot atau tendon untuk menghasilkan relaksasi adalah dengan cara
a. Hidroterapi
b. Masase
c. Hipnobirthing
d. Akupunktur
e. Trancutaneous Electrical Nerve Stimulation (TENS)

\section{Daftar pustaka}

Baston, Helen. Hall, Jennifer. And Einion, Alyson Henley. 2013. Praktik dasar (midwifery Essential) aluh Bahasa Sari Isneini. Volume 1. Jakarta: EGC

Hidayat, A. Aziz Alimul dan Uliyah, M. 2011. Buku Saku Prosedur Ketrampilan Dasar Praktik Klinik. Surabaya: Health Books Publishing 
Kiswari, R. Hematologi dan Tranfusi. Penerbit : Erlangga. 2014.jakarta.

Nuryati.2017. Farmakologi. PPSDM Kemenkes RI : Jakarta

Pratiwi, A. 2019. Buku Ajar Ketrampilan Dasar Kebidanan. Jakarta: Salemba Medika.

Perry, Potter. 2009. Fundalmental of Nursing (fundamental keperawatan). Edisi 7. Translator. dr. Adrina Federika. Jakarta: Salemba Medika

Siti Cholifah, 2016. Pengaruh Aromaterapi Inhalasi Lemon Terhadap Penurunan Nyeri Persalinan Kala I fase Aktif.

Uliyah,M, Wildan M., Surachmindari dan Hidayat, A. Aziz Alimul. 2012. Ketrampilan Dasar Kebidanan I (pendekatan kurikulum Berbasis Kompetensi). Surabaya: Health Books Publishing

Yuni, Natalia E Dan Oktami, Rika S. 2014. Ketrampilan Dasar Praktik Klinik Kebidanan . Yogyakarta: Nuha Medika.

http://keterampilandasarkesehatan.blogspot.com/2018/08/lengkap -metode-pemberian-obat-injeksi.html

http://xfarmakologi.blogspot.com/2016/09/cara-pemberianobat.html 


\section{DAFTAR PUSTAKA}

Baston, Helen. Hall, Jennifer. And Einion, Alyson Henley. 2013. Praktik dasar (midwifery Essential) aluh Bahasa Sari Isneini. Volume 1. Jakarta: EGC

Hidayat, A. Aziz Alimul dan Uliyah, M. 2008. Ketrampilan Dasar Praktik Klinik untuk Kebidanan. Edisi 2. Jakarta: Salemba Medika

Hidayat, A. Aziz Alimul dan Uliyah, M. 2011. Buku Saku Prosedur Ketrampilan Dasar Praktik Klinik. Surabaya: Health Books Publishing

JNPKR. JHPIEGO. 2004. Panduan Pencegahan Infeksi. Jakarta. YBP-SP

Kasiati., Rosmalawati, Ni Wayan Dwi. 2016. Kebutuhan Dasar Manusia. Jakarta : Pusdik SDM

Kiswari, R. Hematologi dan Tranfusi. Penerbit : Erlangga. 2014.jakarta.

Nursing Drug Handbook. (2012). Lippincott Williams \& Wilkins: Philadelphia, Pennsylvania.

Nuryati.2017. Farmakologi. PPSDM Kemenkes RI : Jakarta

Peraturan Menteri Kesehatan No. 27 Tahun 2017 tentang pedoman pengendalian Infeksi di Fasilitas Pelayanan Kesehatan

Pratiwi, A. 2019. Buku Ajar Ketrampilan Dasar Kebidanan. Jakarta: Salemba Medika. 
Perry, Potter. 2009. Fundalmental of Nursing (fundamental keperawatan). Edisi 7. Translator. dr. Adrina Federika. Jakarta: Salemba Medika

Siti Cholifah, 2016. Pengaruh Aromaterapi Inhalasi Lemon Terhadap Penurunan Nyeri Persalinan Kala I fase Aktif.

Sutanto, Andina Vita. Fitiana. Yuni. 2017. Kebutuhan Dasar ManusiaTeori dan aplikasi dalam Praktik Keperawatan professional

Uliyah,M, Wildan M., Surachmindari dan Hidayat, A. Aziz Alimul. 2012. Ketrampilan Dasar Kebidanan I (pendekatan kurikulum Berbasis Kompetensi). Surabaya: Health Books Publishing

Undang-Undang Kesehatan No. 23 Tahun 1992

Undang-Undang Kesehatan No. 36 Tahun 2009

Yuni, Natalia E Dan Oktami, Rika S. 2014. Ketrampilan Dasar Praktik Klinik Kebidanan . Yogyakarta: Nuha Medika.

https://spo-keperawatan.blogspot.com/2016/06/spo-pengelolaanobat-lasa.html

https://rekayasahijau.com/id/produk-dan-jasa/incinerator/

http://identitaspasien.arata.co.id/produk/gelang-pasien/

http://keterampilandasarkesehatan.blogspot.com/2018/08/lengkap -metode-pemberian-obat-injeksi.html

http://xfarmakologi.blogspot.com/2016/09/cara-pemberianobat.html 


\section{BIODATA PENULIS}

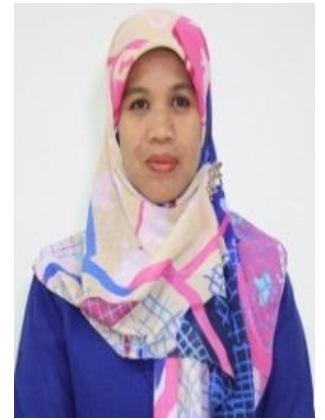

Siti Cholifah., SST., M.Keb. lahir di Sidoarjo, 5 Januari 1979. Lulus Sarjana Pada tahun 2005, penulis mendapatkan gelar Sarjana Sains Terapan dari Universitas Padjadjaran Bandung. Penulis melanjutkan magister kebidanan dengan program beasiswa dari Institusi lulus tahun 2016, penulis secara resmi mendapatkan gelar M.Keb. dari Universitas Aisyiyah Yogyakarta. Penulis mengawali karirnya sebagai pengajar di AKBID siti khodijah yang pada tahun 2003, pada tahun 2013, AKBID bergabung dengan Universitas Muhammadiyah Sidoarjo penulis sebagai Dosen di prodi Kebidanan Universitas Muhammdiyah Sidoarjo.

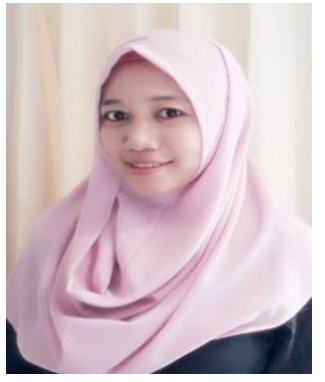

Nurul Azizah., S.Keb., Bd., M.Sc. dilahirkan di Sidoarjo, 25 Mei 1985. Pada tahun 2011, lulus Sarjana Pendidikan Bidan di Universitas Airlangga Surabaya. Penulis melanjutkan studi S2 di Prodi Ilmu Kedokteran Klinik Peminatan Maternal Perinatal di Universitas Gadjah Mada Yogyakarta. Tahun 2015, penulis secara resmi mendapatkan gelar M.Sc. saat ini penulis sebagai Dosen Kebidanan Fakultas Ilmu Kesehatan Universitas Muhammdiyah Sidoarjo. Beberapa penelitian yang pernah dilakukan oleh penulis adalah tentang pengembangan klinik ilmu kebidanan 
